\title{
Transforming Non-Renewable Resource Economies (NREs)
}




\section{WP/15/171}

\section{IMF Working Paper}

\section{Transforming Non-Renewable Resource Economies \\ (NREs)}

by Bill Battaile and Saurabh Mishra

IMF Working Papers describe research in progress by the author(s) and are published to elicit comments and to encourage debate. The views expressed in IMF Working Papers are those of the author(s) and do not necessarily represent the views of the IMF, its Executive Board, or IMF management.
I N T E R N A T I O N A L
$M O N E T A R Y$
$F \cup N D$ 


\title{
IMF Working Paper
}

\author{
Research Department
}

\section{Transforming Non-Renewable Resource Economies (NREs) \\ Prepared by Bill Battaile and Saurabh Mishra* \\ Authorized for distribution by Prakash Loungani}

July 2015

\begin{abstract}
IMF Working Papers describe research in progress by the author(s) and are published to elicit comments and to encourage debate. The views expressed in IMF Working Papers are those of the author(s) and do not necessarily represent the views of the IMF, its Executive Board, or IMF management.
\end{abstract}

\begin{abstract}
This paper provides an empirical benchmarking of growth, productivity and export patterns for developing NREs against other low and middle income developing countries, to inform policy discussions and future analytical work. There is stark heterogeneity in the association of resource sector and overall growth outcomes, by commodity and degree of dependence. Over the long term, inter-sectoral growth dynamics have been more muted for NREs than other developing countries, especially at lower incomes. Despite productivity convergence in mining, as expected, productivity growth in manufacturing and services was generally lower in NREs. Exceptions are few, in East Asia and the CIS area which experienced broad-based productivity growth. NRE product exports are more concentrated and relatively less complex, though we find increasingly diversified service export baskets. Technological progress and specialization in trade in services may offer diversification options for the future.
\end{abstract}

JEL Classification Numbers: F01, O4

Keywords: resource curse, diversification, manufacturing, services, comparative advantage Author's E-Mail Address: bbattaile@worldbank.org; smishra2@imf.org

\footnotetext{
* We thank Daron Acemoglu, Rabah Arezki, Kemal Dervis, Romain Duval, Poonam Gupta for thoughtful discussions and comments on an earlier draft of this paper. Any errors are solely ours.
} 


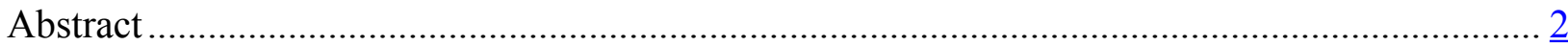

I. Introduction and Motivation ................................................................................... 4

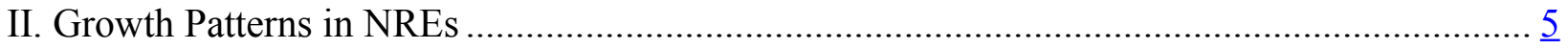

A. Defining "Resource-Led" Growth ............................................................................. $\underline{6}$

B. Muted Sectoral Dynamics ....................................................................................... 7

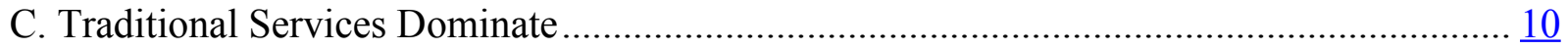

III. Labor Productivity Growth ..................................................................................... 11

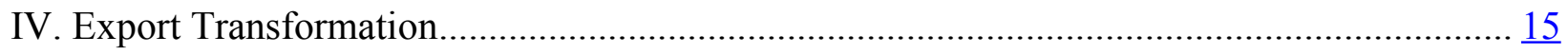

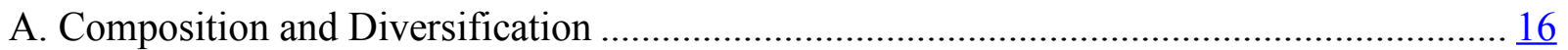

B. Quality and Complexity .......................................................................................... 19

C. Product Space and Specialization ........................................................................... 21

V. Concluding Remarks ........................................................................................... 26

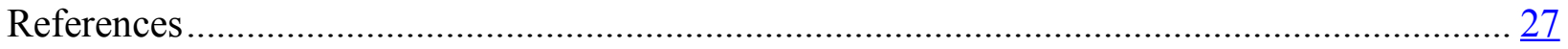

Annexes

1. List of Non-Renewable Resource Economies (NREs) ................................................... $\underline{32}$

2. Technical Notes on Trade Analysis .......................................................................... 33

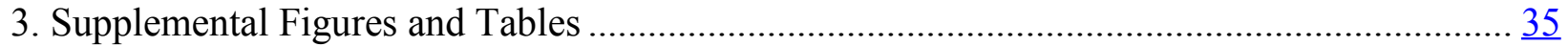




\section{INTRODUCTION AND MOTIVATION}

There has been renewed focus in the literature on the role of structural transformation in economic development and growth. ${ }^{2}$ This is a particularly important issue for developing nonrenewable resource economies (NREs) which face unique transformation challenges. ${ }^{3}$ For example, resource sectors tend to be highly capital intensive and offer limited employment opportunities to accommodate workers exiting sectors with lower average productivity, such as agriculture and informal services. In addition, NREs can face significant Dutch disease effects, including solely from a shift in demand following a resource discovery. ${ }^{4}$ Policymakers thus often seek a more balanced growth model in NREs, aiming for resource rents to fuel productivity gains in the non-resource sectors.

Impressive NRE growth during resource-driven booms can mask deeper structural issues that are critical for long term development. The underlying sources of growth and structures of production are key to the sustainability and distribution of benefits from rising national incomes. This has driven a keen interest among NRE policymakers to explore ways to promote nonresource sectors of their economies, both for growth and volatility management reasons. Performance to date has been mixed on resource booms delivering the longer term structural change consistent with sustained development and higher per capita incomes. It is also important to note global diversification patterns, which vary by income levels. More rapid diversification spurts are linked with early stages of economic development (Cadot et al., 2013). Export diversification is associated with greater macroeconomic stability, through lower vulnerability to shocks and lower terms of trade volatility (Lederman and Maloney, 2012). Overall, diversification in Low Income Countries (LICs) shows an overall shift in resources from sectors where prices are highly volatile and correlated, such as mining and agriculture, to less volatile and correlated sectors, such as manufacturing, resulting in greater stability (Koren and Tenreyro, 2007). Thus it is imperative for NRE policymakers to know how the structural change in their economies compares to other countries. However, the economic narrative of transformation (or the lack thereof) in the structure of production of NREs remains scarce.

This paper addresses this gap by taking a cross-country empirical approach to benchmarking NREs against other countries along key growth-related dimensions. In the process, the paper utilizes new and existing data on value added, drivers of sectoral output per worker, and exports. The analysis decomposes the sectoral contributions to GDP, productivity,

\footnotetext{
${ }^{2}$ Structural transformation is broadly defined as the reallocation of resources from low to high value added tasks or sectors. For recent discussions of the importance of structural transformation and development, see Timmer and Akkus (2008), Gelb (2010), Ocampo et al (2009), McMillan and Rodrik (2011), Dabla-Norris et al (2013) and Rodrik (2015).

${ }^{3}$ See Annex 1 for the default list of NREs used in the paper, defined along the lines of IMF (2012) based on the importance of resource rents to public revenues and exports. Specific analyses may apply to subsets of this list, depending on data availability.

${ }^{4}$ Recent insight into how an unequal distribution of the rents from resource wealth can further intensify Dutch disease dynamics is discussed in Battaile, Chisik and Onder (2014).
} 
and trade growth over time in NREs. We also play special attention to the role of services in the structure of production in NREs, given there is often increased activity in the service sectors that accompanies resource booms. Recent empirical work on the dynamics of service sector growth has helped clarify the positive relationship between the service sector share of output and per capita income. Eichengreen and Gupta (2013) identify two waves of service sector growth in their sample of mostly industrialized countries - a first wave in countries with relatively low levels of per capita GDP and a second wave in countries with higher incomes. Thus, a key question for NREs is how sustainable any service sector growth is, and how it links to other sectors of the economy, especially if it is driven largely by consumption of resource rents versus a more sustainable move to more modern sectors.

The paper is structured as follows. Section 2 takes stock of sectoral drivers to growth over the past few decades in NREs compared to other countries at similar stages of development. Section 3 takes a more microeconomic approach to growth patterns by looking at differences in productivity across sectors. Section 4 documents relative performance in the competitiveness of product and service exports. We provide concluding comments in Section 5.

\section{Growth Patterns In NRES}

We begin by documenting resource-led growth and the changing structure of production over the last 30 years across NREs. This section sets out to answer three questions. What is meant by "resource-led" growth? How have sectoral contributions to GDP growth shifted over time in NREs, relative to other countries? What has been the role of the service sectors in changes to the structure of production?

Globally, the sources of GDP growth have shifted toward services, now accounting for a majority of growth for low, middle and high income groups of countries. Overall, there has been a shift in economic activity out of agriculture and manufacturing, and into the service sectors. There has been a marked increase in the average share of GDP growth derived from the service sectors, from two-thirds in the 1980s to nearly three-quarters in the 2000 s.

Non-renewable resource economies largely escaped the worst of the global crisis, with significantly better aggregate growth performance than the rest of the world. Over the long term, average real growth for non-renewable resource economies is roughly the same as for other countries-just over 1.5 percent per annum over the last 50 years for oil-producers-though with significantly higher volatility. ${ }^{5}$ The latter point is driven by the movement in export prices these economies depend on. Recent growth outcomes since the global crisis have not been an exception to this overall pattern. Average real GDP growth has been considerably better for NREs, both before and after the crisis, as energy export prices remained buoyant after the shortlived collapse in 2009 (Figure 1). Fiscal and current account balances also initially fared much better. However, the recent decline in commodity prices starting in 2014 has exposed the

\footnotetext{
${ }^{5}$ Ross (2012).
} 
vulnerabilities of NREs. Revenues have declined sharply, and most NREs are implementing expenditure reductions in light of expected continued sluggishness of commodity demand.

\section{A. Defining "Resource-Led" Growth}

What is meant by "resource-led" growth? For an oil exporting country, a possible definition is an episode of positive GDP growth when the oil sector is growing faster than other sectors. However, the growth of the value of barrels produced may be too narrow a measure to capture the full extent of the impact of producing and selling the commodity. There are goods and services that support the oil sector, and the spending of resource rents drives other parts of the economy. These indirect channels of growth from resource sectors can be difficult to quantify, thus precise measurement of "resource-led" growth is problematic. In general, resource-led growth relates to the co-movement between aggregate economic growth and growth in a sizable resource sector.

Resource booms are highly unstable and differ by commodity. Figure 2 illustrates the heterogeneous experience of the value of non-renewable commodity exports over the past 30 years. This "heat map" shows the average annual growth rate of the value of

Figure 1. NREs Weathered Post Global Crisis Period Better Than Other Countries

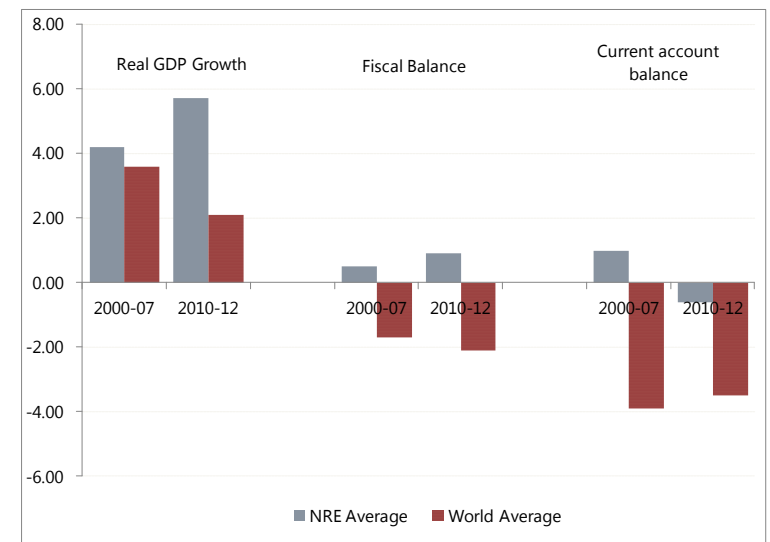

Source: Authors' calculations using World Development Indicators, World Bank, 2014.

Notes: NREs include all countries reported in Annex Table 1. commodity exports across all countries, ranging from above 50 percent growth in red to less than -50 percent in green. Differentiation by commodity is stark. Oil and copper export values have shown high rates of growth for the majority of the period, with relatively few contractions. Iron, minerals and mining have shown more modest, yet mostly positive, growth. In contrast, uranium and gold are exported in low volumes and exhibit more erratic export growth and contraction rates. Figure 2 also shows there has been an increase in average non-renewable commodity export growth since the 2000s, relative to the two previous decades. The data also clearly shows the nearly uniform contraction in the value of exports across commodities in 2009 as the global crisis affected trade across the world.

Resource reliance is volatile over time. The heterogeneity of "resource-led" growth experiences across NREs is shown in Annex 3 Figure I, where the commodity export data shown in Figure 2 is linked with GDP time series for 30 NREs with available data. In Panel A, each annual observation of non-renewable export growth and GDP growth is represented by a box, with the size of the box indicating GDP growth and the color of the box indicating export growth. Strong GDP growth performance is clearly seen for countries like Indonesia, Botswana, and Chile with relatively large boxes consistent over time. Strong episodes of "resource-led" 
growth episodes are captured by consecutive years of large and red boxes. Examples of such episodes in the 2000s include Zambia (copper), Bolivia (gas) and Azerbaijan (oil). Similar to Figure 2, the universal collapse in commodity exports in 2009 is starkly apparent, though with differing effects on GDP growth across countries. Panel B presents export growth (color) with the relative importance of the non-renewable commodity exports (size), proxied by the share of export value as a percentage of GDP. This allows us to differentiate the NREs, for example into countries where export revenues from non-renewable commodities are relatively modest, such as Mexico, versus very resource dependent countries such as Gabon, Angola, Nigeria and Libya. Annex 3 Figure 1 Panel B also shows this dependence can vary dramatically over time, such as boom years in the importance of gold in Liberia in the early 1990s or volatile oil booms in Turkmenistan in the 1990s.

\section{Figure 2. Non-Renewable Resource Export Growth by Commodity}

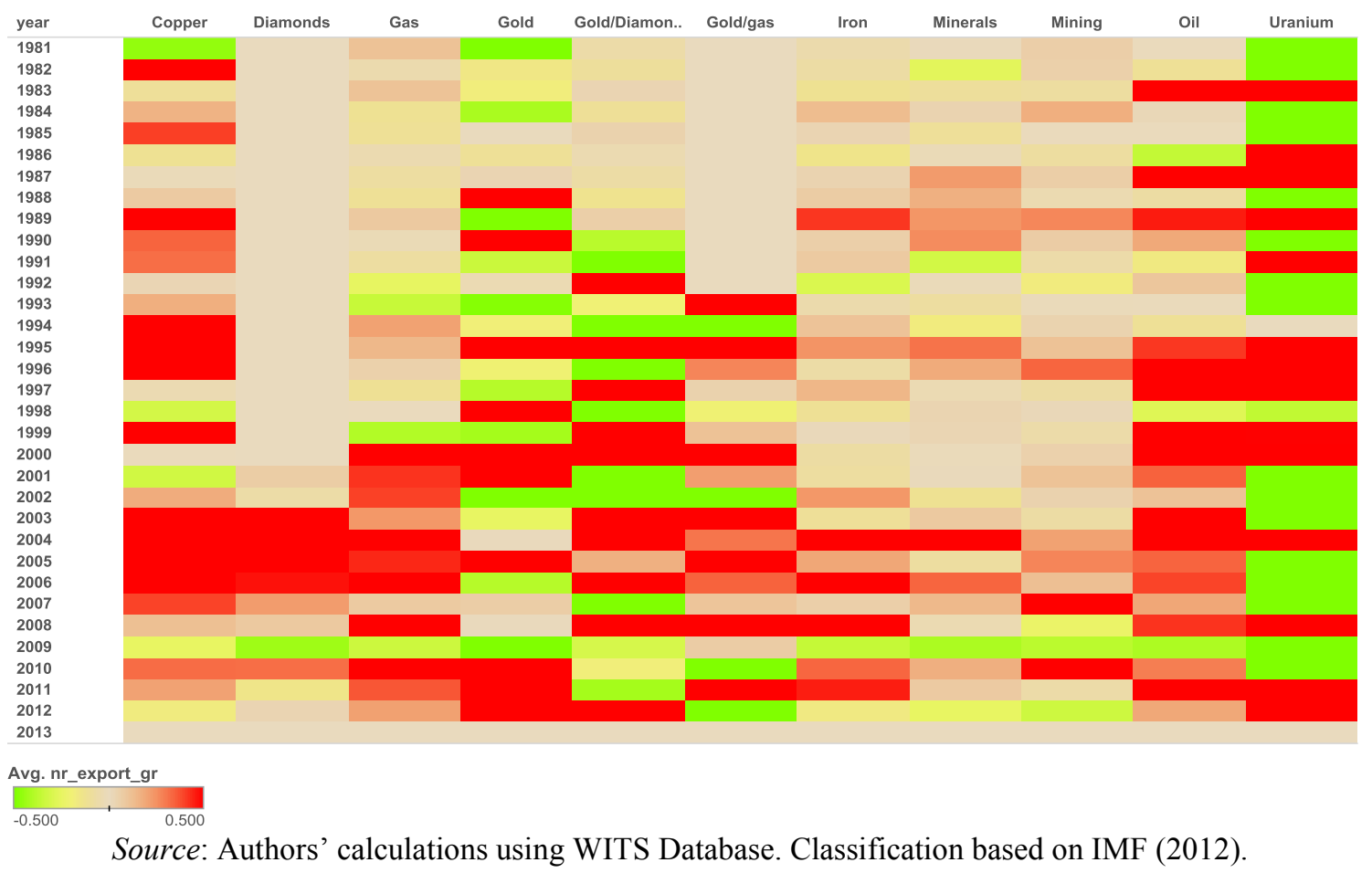

\section{B. Muted Sectoral Dynamics}

How have sectoral contributions to GDP growth shifted over time in NREs, relative to other countries? This section considers this question using cross-country data and focusing on our sample of 40 NREs mentioned above.

Services have become the prime driver of growth. Figure 3 Panel A shows the disaggregation of value-added shares by decade since the 1980s for 122 developing countries, as well as a breakdown by income group. Consistent with the literature, the aggregate data show an overall shift in the sources of growth from agriculture to services, with manufacturing stagnant. 
This overall pattern generally holds across income groups, though the levels of agriculture (services) are lower (higher) as income increases. Dynamism appears positively related to income. Larger increases in the sectoral contribution of services to gross value added are found in middle income countries. Low income countries start from a lower base of service sector gross value added, and the increase is more muted between the 1980s and 1990s. However, the gains from the 1990s to 2000s are roughly equal for all income groups (about 2 percentage points). In the context of non-renewable resources, it is useful to disaggregate industry into manufacturing and non-manufacturing, with the latter including the production of resource sectors such as oil, gas and minerals. Non-manufacturing industry has increased in low income countries, while declining in lower and upper middle income countries.

Do these overall patterns hold for NREs? Figure 3 Panel B shows a contrasting picture for this group of countries. As expected, non-manufacturing industry contributes a much larger share to GDP (30 percent on average for 2000-10) than other countries (13 percent for the same period). Agriculture and services are accordingly smaller. More surprising is the lack of dynamism of sectoral contributions for NREs. For example, the contribution of services remains low, unchanged at 40 percent for the 2000s relative to the 1980 s. The shares for other activities also remain surprisingly stagnant.

These dynamics differ across income groups of NREs. For resource-dependent countries, the shares of services and non-manufacturing industry rise with income. In addition, the longterm increase in services is larger for higher income countries. Services have even slightly contracted among low income resource-rich countries in favor of non-manufacturing industry. A more nuanced picture emerges when considering growth shares by income levels rather than the income groups. Annex 3 Figure II Panel A shows shifts in sectoral shares of GDP from the early 1990s to the most recently available data using the per capita log of GDP. The lower share of agriculture for richer NREs (downward sloping fit) is in line with the pattern for non-NREs (top panel of two charts). However, industry's share of GDP (middle panel) is generally higher than non-NREs, while services (bottom panel) are lower on average. Decomposing industry provides a clearer picture of the trend in the middle panel given this includes most of the nonrenewable resource extraction is included in industry. Annex 3 Figure II Panel $\mathrm{C}$ shows that focusing on only manufacturing activity within industry yields a different picture. The majority of NREs have lower shares of manufacturing than other countries at equal levels of income. Thus the aggregate result for industry in Figure 3 is driven by non-manufacturing industry (related to resource sectors). 
Figure 3. Shift in Sectoral Shares, by NRE Income Group

Panel A. Value Added Shares, by Income Group

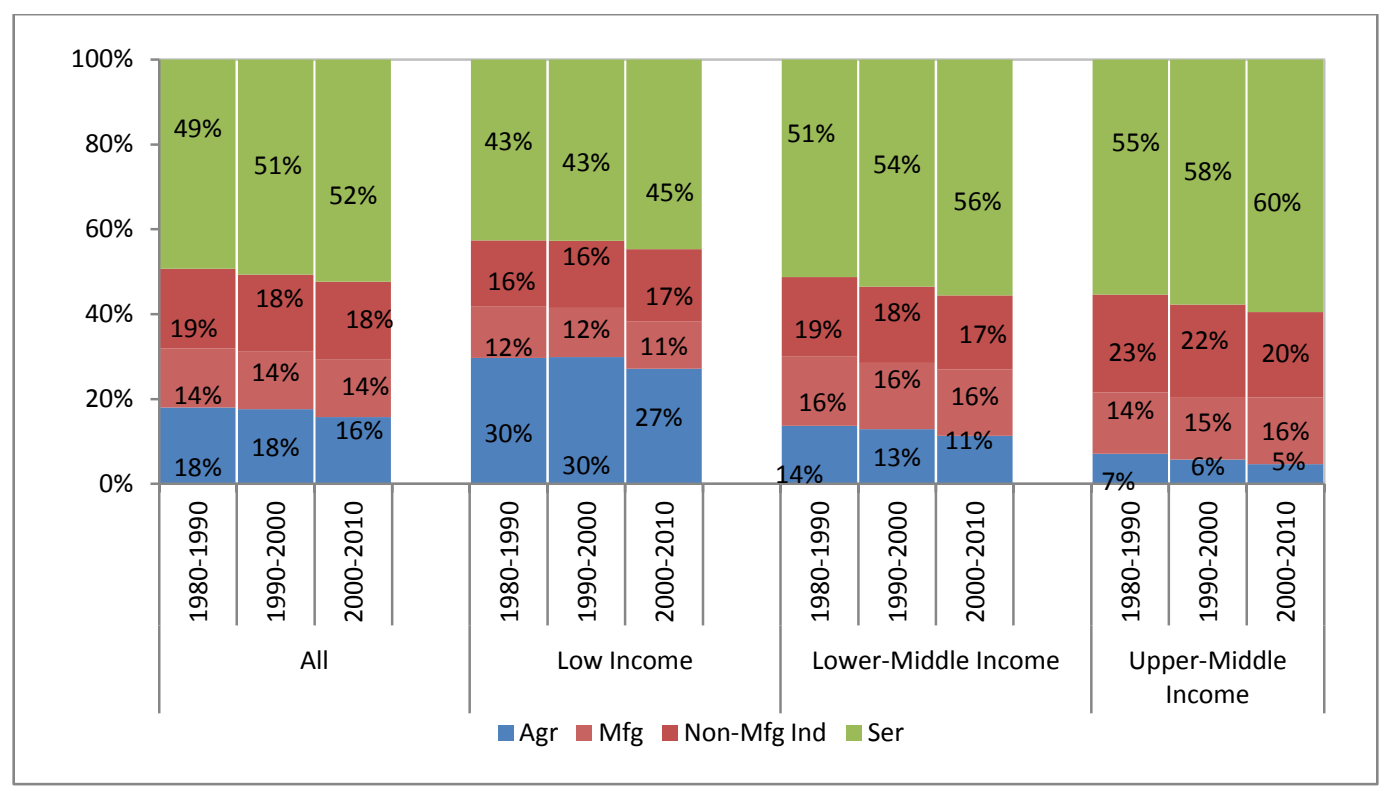

Panel B. Value Added Shares for NREs and Non-NREs, by Income Group

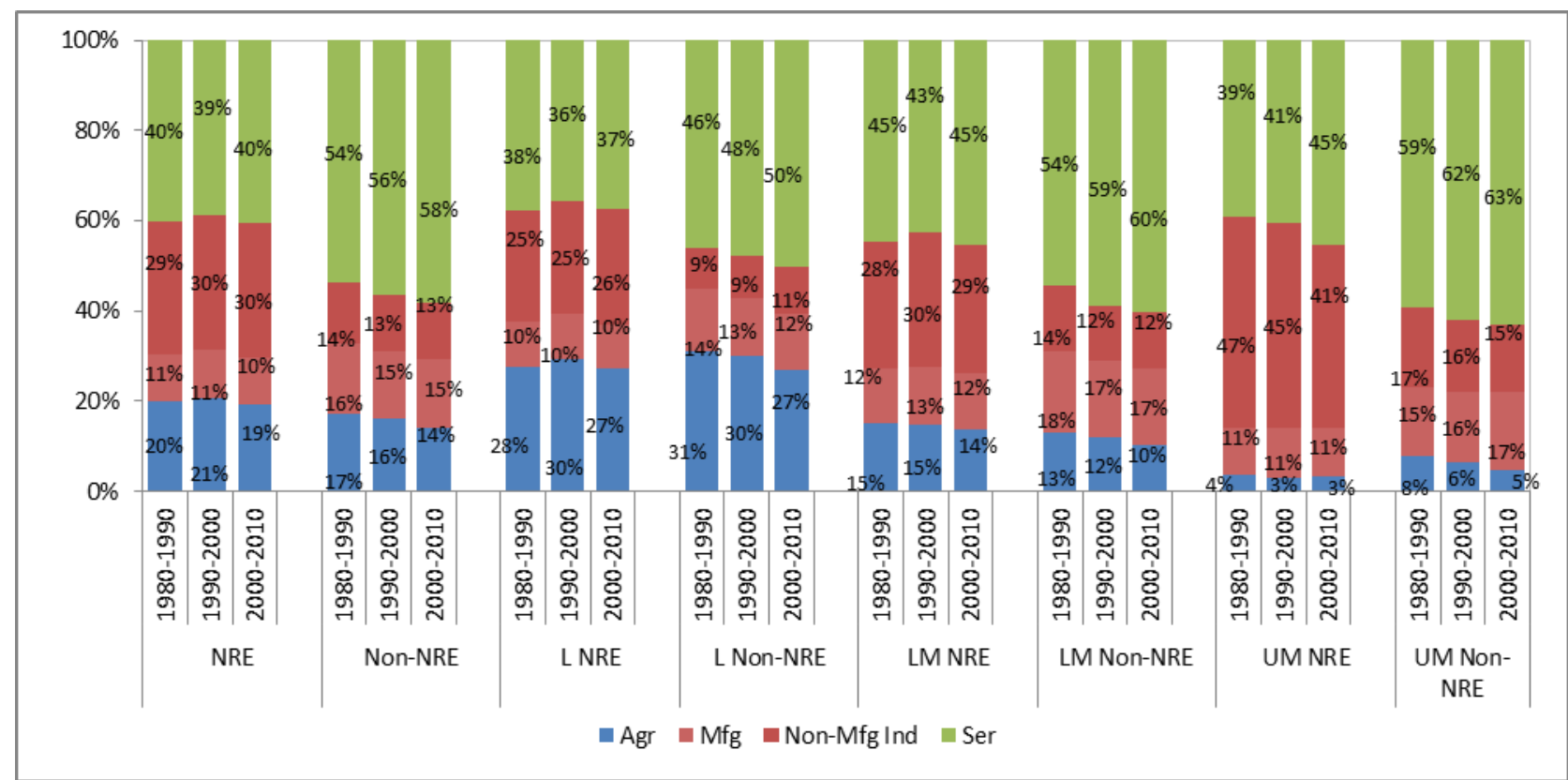

Source: Authors' calculations World Development Indicators, World Bank, 2014. 


\section{Traditional Services Dominate}

What has been the role of the service sectors in changes to the structure of production? Using more disaggregated data on services, wholesale and retail trade is the dominant subsector for NREs (Figure 4). This finding applies for both the 1990s and 2000s. In terms of income groups, wholesale and retail trade contributes the biggest share to services for low and lowermiddle income countries. However, for upper-middle income countries the high-value group of financial intermediation / real estate / renting / business activities is the most dominant sector. It is important to note this analysis includes a restricted set of NREs given data constraints.

Disaggregated data on a comprehensive set of services since the 1990s is available for only a limited set of NREs. ${ }^{6}$

The relative share of traditional services declined. An alternative disaggregation of services is provided in Eichengreen and Gupta (2013), breaking services into traditional, hybrid and modern. ${ }^{7}$ Using a new dataset that allows the application of this typology for 22 NREs, traditional services contribute the majority of services in resource-dependent countries, regardless of income classification. Overall the share of traditional services decreased from 25 percent of total value added in the 1990 s to 20 percent in 2000s. The traditional sector drove the contraction of service sector shares from the 1990s to 2000s. Traditional shares were the largest, and its decline was the biggest for lower-middle income countries. ${ }^{8}$

There is scope for growth to be driven by modern services for some NREs. A simple regression between service shares and income for the overall sample of 22 resource-dependent countries with detailed service data does not support the two-wave growth phenomenon. Looking further into specific services subsectors, there were no inflection points for significant increases in traditional and hybrid services. The share of modern services, on the other hand, is positively (and linearly) associated with income per capita. It has a quartic relationship with income per capita at a 10 percent level of significance. Changes in the shares of hybrid and

\footnotetext{
${ }^{6}$ Analysis for this section are taken from Battaile and Villareal (2014) which looks at the disaggregation of service sector data drawing from the UN Statistics Division Database, augmented with additional data taken from country national accounts data from 1990 to 2010. Only 22 of the original 40 non-renewable resource-dependent countries have this detailed breakdown.

7 They defined traditional services to include wholesale and retail trade, transport and storage, and public administration and defense. The second group is a hybrid of traditional and modern services consumed mainly by households, including education, health and social work, hotels and restaurants, and other community, social and personal services. The third group of modern services includes financial intermediation, computer services, business services, communication, and legal and technical services. Notably, their sample covered mostly developed countries, while our reduced sample is biased towards the low income countries.

${ }^{8}$ This trend is consistent with Eichengreen and Gupta (2013), which found that the share of traditional services slightly declined from 21.6 percent in 1990 to 20.8 percent in 2000 and 20.7 percent in 2005 . They found two waves of service sector growth - a first wave of service sector growth occurring in countries with relatively low levels of per capita income, leveling out at middle income level (at approximately 2000 PPP US $\$ 1,800$ ), and a second wave in countries with higher per capita income (at roughly US $\$ 3,825$ ), but eventually leveling off a second time.
} 
modern services were also found to have a positive linear relationship with income per capita, suggesting that some NREs at higher levels of income have been able to promote growth in higher productivity services.

Figure 4. Service Sector Value Added Shares, by Income Group for NREs and Non-NREs

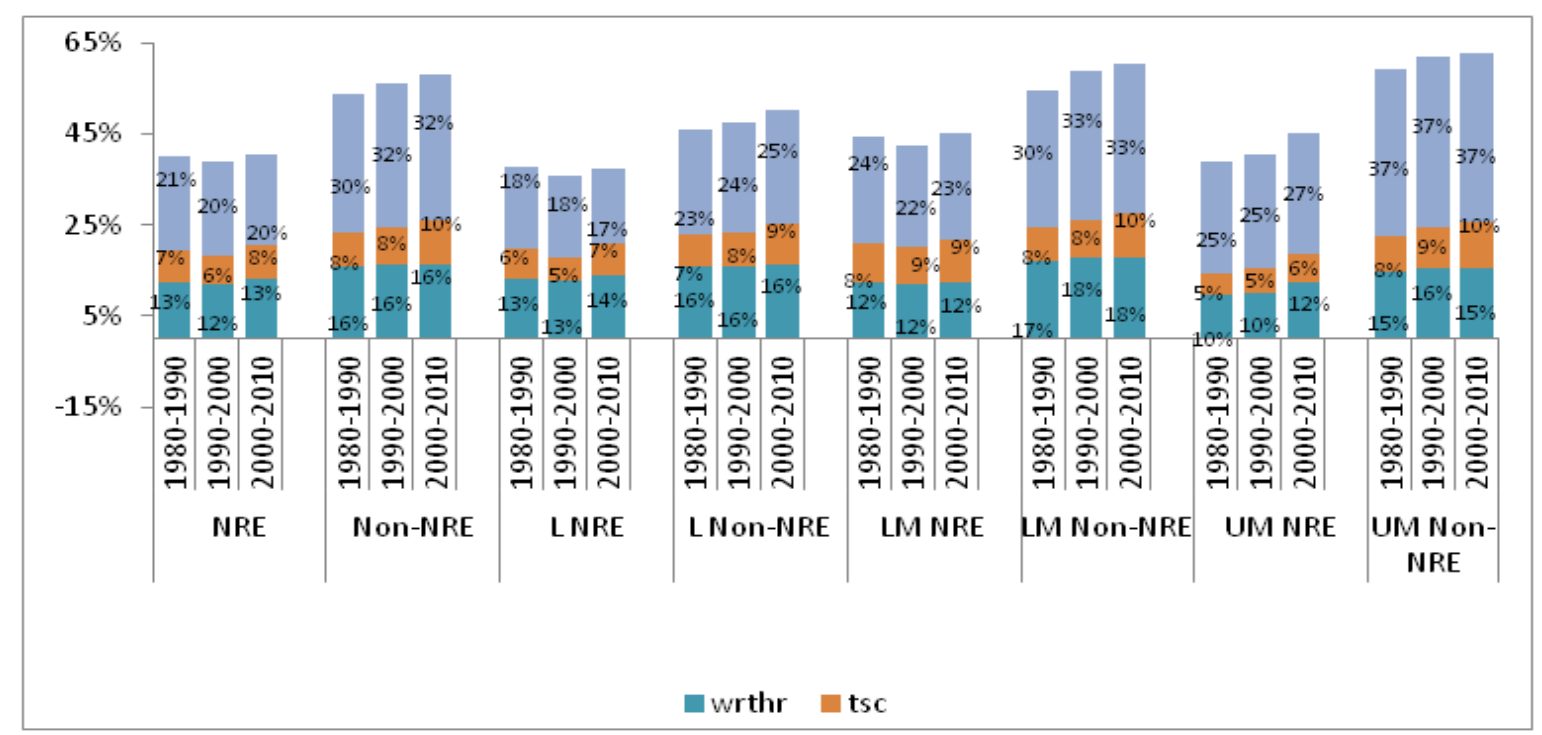

Source: Authors' calculations using World Development Indicators, World Bank, 2014.

\section{LABor Productivity Growth}

Economic growth benefits from the accumulation of endowments that put more inputs to work in the economy, as well as productivity gains that enhance the ability to turn these inputs into outputs. The latter has been shown to explain cross-country variation in measures like income per worker. Helpman (2004) finds more than 60 percent of the differences in levels and 90 percent of the differences in the growth rate of income per worker explained by differences in productivity. Hence, there has been significant attention in development economics on productivity levels and differentials going back to the dual economy modeling of Lewis.

Developing countries are generally characterized by large productivity gaps between sectors of the economy, much larger than for advanced economies. These gaps are an indication of significant allocation inefficiencies across and within sectors. In this regard, the transfer of technologies, know-how, networks, and practices are critical to improve productivity and drive long-run growth. While there has been a global convergence of manufacturing and services productivity, the diffusion of productivity in Africa and Latin America appears to be slower (see MacMillan and Rodrik, 2011; Gelb et al, 2014). For NREs, the resource curse points to a lack of improving productivity in non-resource sectors. How do productivity levels and differentials in 
NREs benchmark against other countries? This section takes an in-depth look at this empirical question. ${ }^{9}$

There is heterogeneity in productivity performance across NREs at similar stages of development. Annex 3 Table I presents the aggregate source of GDP growth in NREs versus non-NREs at similar stages of development. The table is split by time periods. The contribution of capital stock to GDP growth remains the main source of NRE growth. Increasing labor utilization is also a source of productivity enhancement. Emerging market NREs are absorbing more human capital and labor based economic growth. While the residual TFP growth in Emerging Market countries (EMs) remains low, in LICs is comparable to other non-NRE LICs. Annex 3 Table II provides a summary of the contribution to labor productivity growth.

Some NREs have been able to succeed in productivity gains while others are stuck in low or negative productivity changes over time. Countries such as Indonesia, Kazakhstan, Russia, Laos, Mongolia, Vietnam, and Zambia over time show increased productivity growth in the overall economy (see Annex 3 Table III). While the contribution of human capital to productivity growth remains relatively low, capital deepening has played a more important role (see Annex 3 Table IV). The adoption of new technologies that have led to transformation and modernization of the economy has played a much greater role (see Annex 3 Table V).

For given levels of service sector labor productivity, NREs income levels are higher than expected, whereas considering industry productivity their income levels are lower than the global average. In order to benchmark aggregate productivity in NREs against other nations at similar stages of development, we plot Annex 3 Figure III. In Panel A, we plot (the log of) per capita income against (the log of) labor productivity in services and industry. We plot all possible years with available data between 1960 and 2013, and highlight the sample of NREs in red. The charts can be interpreted as predicting a country's income level based on the observed productivity level; countries above the line have income levels higher than would be predicted by their sectoral productivity level (relative to all countries in the world at similar stages of development). Panel A shows that the income levels predicted by their aggregate service labor productivity level in NREs are slightly higher than expected. In other words, service labor productivity is lower in NREs than other countries at similar stages of development. In terms of overall industrial productivity, for most years and most countries, productivity in NREs would predict a slightly higher income level. The level of aggregate industrial productivity is slightly higher in NREs than other countries at similar stages of development. ${ }^{10}$

\footnotetext{
${ }^{9}$ This section leverages new data on sectoral productivity available from the IMF. The data accompany the IMF Staff Discussion Note Anchoring Growth: The Importance of Productivity Enhancing Reforms (IMF, 2014).

${ }^{10}$ Annex 3 Figure III also looks at productivity within the industry (Panel B) and services (Panel C). The size of the bubble represents the size of labor force, and the plots represent the estimated fit between average productivity and incomes between 2008 and 12. Panel B disaggregates industry into manufacturing and mining labor productivity. Except the cases of Algeria, Azerbaijan, or Iran which perform marginally better than average, most NREs (with available data) lag behind in both manufacturing as well as mining. Panel $\mathrm{C}$ disaggregates services into distribution, transport/storage/ communications, and wholesale/retail trade. The story is more mixed in this case, with half of the NRE sample with marginally higher productivity than other countries, and the other half of NREs falling behind in sub-sectoral service productivity.
} 
Dominant resource sectors lead higher capital intensity for the overall economy (which in turns leaves lower labor and labor compensation intensive reallocation). NREs are moving away from labor intensive growth to capital intensive growth, however from a much lower base. The wage share of income (much like the rest of world) is also declining in NREs. However, the trend in decline in wage share in NREs is occurring at much earlier stages than other developing countries (Annex 3 Figure IV). While the share of labor compensation in GDP has been declining for rest of the world, it is declining from much lower levels in NREs. Conversely, capital compensation in GDP continues to increase in NREs compared to other developing countries, even though starting from a more capital intensive base levels.

NREs in Asia and have witnessed comparably faster productivity growth across sectors. Whereas others in Sub-Saharan Africa, Latin America, and Middle East exhibit more concentrated sources of economic growth. Convergence will require eliminating the inter-sectoral productivity differences between these groups. The average annual productivity growth between 2000 and 2012 shows that the median agriculture productivity has growth of almost 4 percent in NREs; this is almost twice that of other developing countries. Similarly, manufacturing productivity has fared better than other developing countries (primarily led by Indonesia, Vietnam, and Russia).

Convergence in fast mining productivity growth across the world masks the catch up across sectors for other NREs. The analysis compares regional growth in sub-sectoral labor productivity in NREs with non-NREs for the period 2000-12 in Tables 1 and 2. In particular, we note that NRE productivity improvements in Eastern Europe and Central Asia have been at par with productivity improvements in the last decades for non-NREs in the same regions. Productivity growth in NREs in Latin America, the Middle East and North Africa, and SubSaharan Africa show more mixed signs. Agriculture, manufacturing, and high-end service productivity growth for NREs in the aforementioned regions has potential for faster catch ups.

Can improvements in service labor productivity drive gains in overall labor productivity for NREs and boost per capita GDP growth? To answer this question, we run a simple econometrics exercise. The analysis uses unbalanced panel data using fixed effect regression data spanning 1960-2013 for 98 countries, controlling for initial conditions. We regress the annual growth in industrial labor productivity, controlling for initial labor productivity in that country against the growth rate of service labor productivity. The overall trend between industrial and service labor productivity has a positive and statistically significant relationship. The coefficient elasticity is presented in Annex 3 Figure V. One unit of growth in service labor productivity yields over 0.5 percent increase in industrial labor productivity. This magnitude is slightly larger for NREs. Similarly, the second panel plots the elasticity by regions for growth in service labor productivity on per capita GDP growth. Again, we note that one unit of labor productivity growth in service for NREs yields output growth to increase by 0.25 percent, a magnitude that is higher for NREs than other economies at various stages of development. ${ }^{11}$

\footnotetext{
11 Recent studies have found a positive impact of liberalization of services - in terms of behind the border restrictions in mobility of people, capital, and investment - leading to overall improvements in growth and productivity (see Arnold et al, 2012 and Javorcik and Li, 2008).
} 
These back of the envelope calculations demonstrate that productivity gains in services have generally had a positive impact on overall economic and productivity growth in NREs.

Table 1. Productivity Growth Across Regions

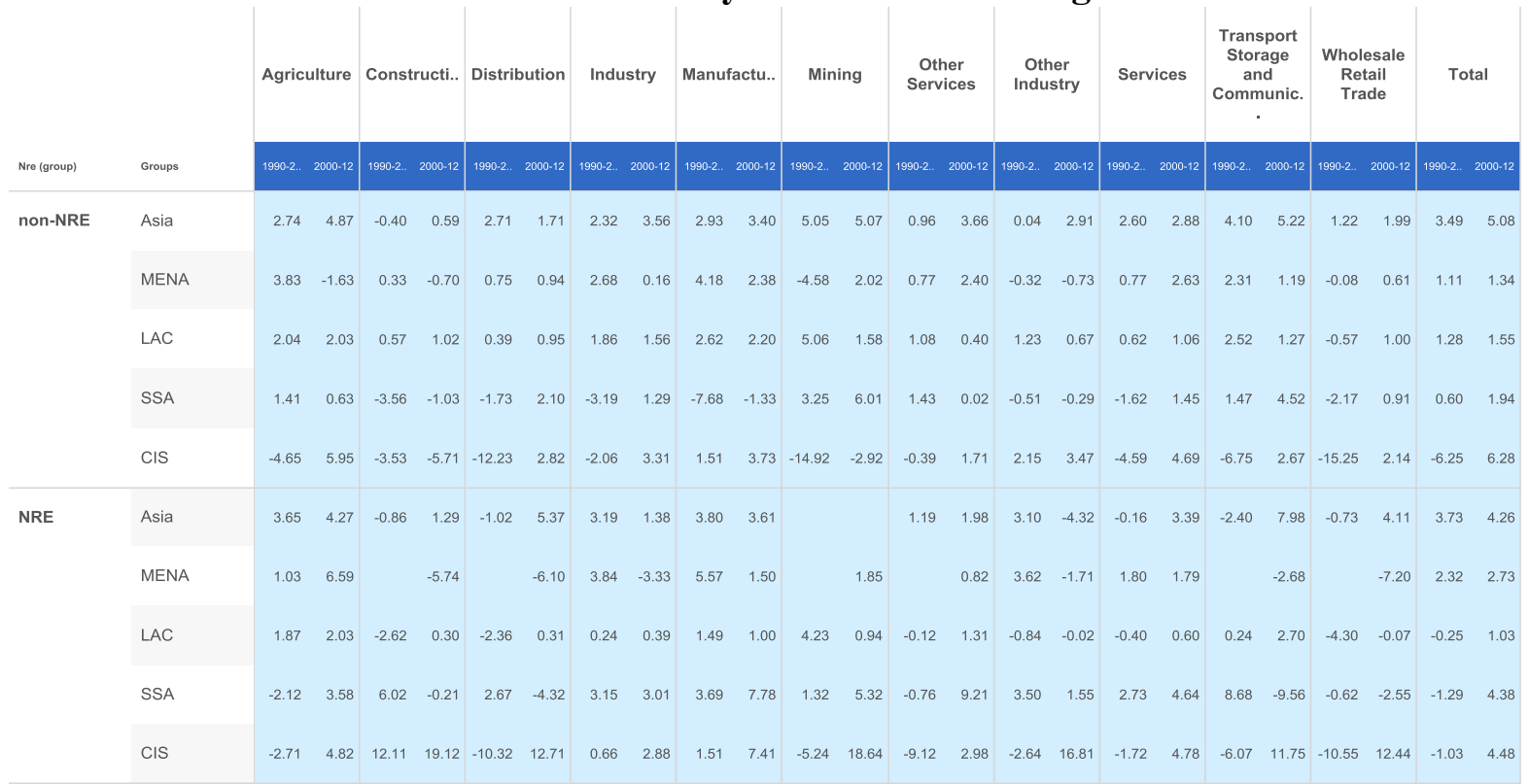

Source: authors' calculations based on IMF (2014).

Table 2. Accounting for Productivity Growth Across Sectors in NREs, 2000-12

\begin{tabular}{|c|c|c|c|c|c|c|c|c|c|c|c|c|c|}
\hline Groups & Country & Agriculture & Constructi... & Distribution & Industry & Manufactu.. & Mining & $\begin{array}{r}\text { Other } \\
\text { Industry }\end{array}$ & $\begin{array}{r}\text { Other } \\
\text { Services }\end{array}$ & Services & $\begin{array}{r}\text { Transport } \\
\text { Storage } \\
\text { and } \\
\text { Communic. }\end{array}$ & $\begin{array}{r}\text { Wholesale } \\
\text { Retail } \\
\text { Trade }\end{array}$ & Total \\
\hline \multirow[t]{2}{*}{ Asia } & Vietnam & 5.14 & & & 1.54 & & & & & 2.77 & & & 5.09 \\
\hline & Indonesia & 3.40 & 1.29 & 5.37 & 1.22 & 3.61 & & -4.32 & 1.98 & 4.01 & 7.98 & 4.11 & 3.43 \\
\hline \multirow[t]{3}{*}{$\mathrm{CIS}$} & Azerbaijan & 4.82 & 19.12 & 12.71 & 16.41 & 7.41 & 18.64 & 16.81 & 2.98 & 8.40 & 11.75 & 12.44 & 14.24 \\
\hline & Mongolia & 2.61 & & & 2.39 & & & & & 4.78 & & & 4.48 \\
\hline & Russia & 6.70 & & & 2.88 & & & & & 4.12 & & & 4.02 \\
\hline \multirow[t]{6}{*}{ LAC } & Mexico & 2.03 & 1.76 & 1.66 & 3.09 & 3.14 & 1.71 & 1.85 & 1.86 & 1.73 & 2.72 & 1.31 & 2.22 \\
\hline & Ecuador & 1.95 & 6.28 & -1.04 & 4.54 & 1.86 & 11.23 & 6.68 & 0.48 & -0.52 & -0.39 & -1.45 & 1.10 \\
\hline & Chile & 3.85 & 0.39 & 2.64 & 0.49 & 3.01 & 0.17 & -1.89 & 1.31 & 1.78 & 2.88 & 2.68 & 1.03 \\
\hline & Venezuela & 1.93 & 0.20 & 4.57 & -1.81 & 0.15 & -7.63 & -4.21 & 1.34 & 2.83 & 2.67 & 4.93 & 0.86 \\
\hline & Bolivia & 4.94 & -4.56 & -3.56 & 0.29 & -3.29 & 21.86 & 4.10 & 1.31 & -1.68 & -0.28 & -5.00 & 0.64 \\
\hline & Suriname & & -17.27 & -5.76 & -14.09 & -12.75 & -21.41 & -18.21 & -11.56 & -8.82 & 5.85 & -9.18 & \\
\hline \multirow[t]{4}{*}{ MENA } & Iran & 5.85 & & & 4.91 & 9.70 & & 2.08 & & 4.38 & & & 5.89 \\
\hline & Syria & 7.32 & & & -1.45 & & & & & 3.19 & & & 2.85 \\
\hline & Yemen & 10.36 & & & -6.80 & & & & & 0.40 & & & 2.61 \\
\hline & Algeria & 0.37 & -5.74 & -6.10 & -5.21 & -6.69 & 1.85 & -5.50 & 0.82 & -1.71 & -2.68 & -7.20 & -2.49 \\
\hline \multirow[t]{3}{*}{ SSA } & Nigeria & 8.54 & -0.21 & 6.87 & 3.01 & 7.78 & 5.32 & 1.55 & 1.81 & 6.19 & -9.56 & 9.06 & 5.63 \\
\hline & Zambia & -1.38 & 14.42 & -4.32 & 3.49 & -4.80 & 6.99 & 11.24 & 12.72 & 4.24 & 0.90 & -5.57 & 3.14 \\
\hline & Botswana & & -42.26 & -4.63 & -12.28 & 10.04 & -20.25 & -25.64 & 9.21 & 4.64 & -14.02 & -2.55 & \\
\hline
\end{tabular}

Source: authors' calculations based on IMF (2014). 


\section{EXPORT TRANSFORMATION}

Exports from NREs have increased since the early-1990s - both as a share of GDP and as a share of world exports (Figure 5). Not surprisingly this is largely driven by oil and mining based exports. The exports of goods from NREs constituted 5.6 percent of world goods exports in 1994, and subsequently grew to around 7 percent at the turn of the century and to almost 10 percent in 2013. Service exports from NREs account for around 4 percent of world service exports in 2013. Changing global consumer demand has been a key driver for this increase, as fuel-exporting economies have been able to increase the targeting of merchandise exports away from advanced economies and more toward emerging and developing markets (see Figure 6). ${ }^{12}$

Trade in services has grown, though in contrast to other countries import demand has far outstripped the growth in exports. NRE service exports have grown marginally in world market. Service exports grew from 3.1 percent in 2000 to around 4 percent in world service exports market in 2013. However, in net terms there is a stark difference of NRE experience compared to other countries. Figure 7 shows net services, defined by service exports / service imports, for both country groups. On average, non-NREs exported significantly more services than they imported between 2000 and 2012. NREs, in contrast, showed the opposite pattern of importing relatively more services, perhaps driven by Dutch disease effects from the spending of resource

Figure 5. NRE Exports of Goods and Services

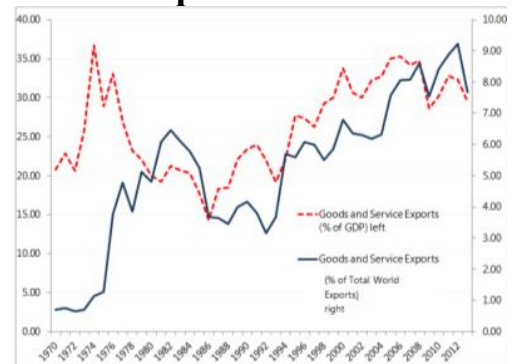

Source: Authors' calculations using WDI, World Bank, 2015.

Figure 6. Destination of Merchandise Exports from Fuel Exporting Countries (\% of total merchandise exports)

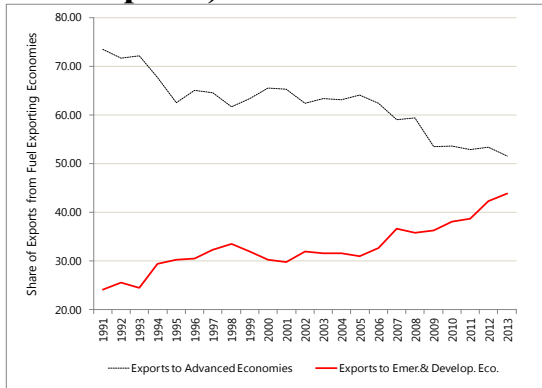

Source: Authors' calculations using Direction of Trade Statistics, IMF (2014).

Figure 7. Service Exports / Service Imports

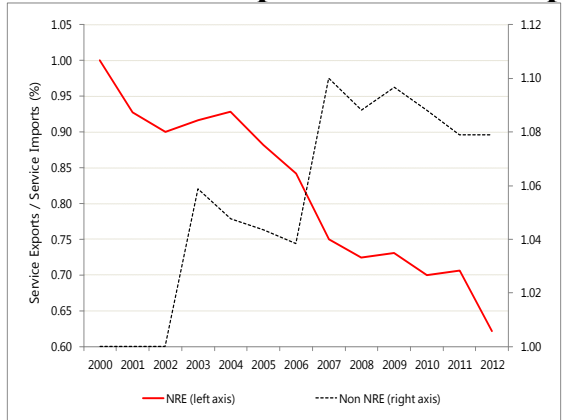

Source: Authors' calculations using BPM5, IMF 2014.

Note: Both axis are service exports/service imports (\%).

\footnotetext{
${ }^{12}$ Throughout the paper for service exports we use the BPM5 detailed classification data unless noted otherwise. We ran robustness tests with BPM6 Working data as well (results not reported). See Mishra (2015) for details on trade in services statistics and methods.
} 
rents. ${ }^{13}$ In a similar vein, Annex 3 Figure VII Panel A displays service exports in service value added $(\%)$ to gauge tradability of services. The world in general is experiencing a boom in exporting services (relative to services being created at home). However, consumption based services are growing faster in NREs.

\section{A. Composition and Diversification}

Fast-growing developing economies have often transformed their exports toward a strong manufacturing base; comparatively, NREs have room to converge in manufacturing exports. ${ }^{14}$ Aggregate statistics can mask the scale and scope of transformation in NREs. Aggregate manufacturing exports from NREs seem to be growing at par with peer economies, given from a low base (Figure 8). The aggregate share of manufactured exports from specific NREs does not seem as starkly different from other fast growing economies (see Figure 9). Countries like Suriname, Niger, and Bahrain exhibit a relatively high share of manufacturing exports. However, more examination will illustrate that for some of these economies, the transformation to manufacturing is a residual of the statistical classification system. Therefore, in Figure 10 we aggregate NREs' manufacturing exports by communities of products. The majority of manufactured exports are related to processed oil and other resource based exports.

Figure 8. Manufacturing Export Growth Figure. 9. Share of Manufacturing in

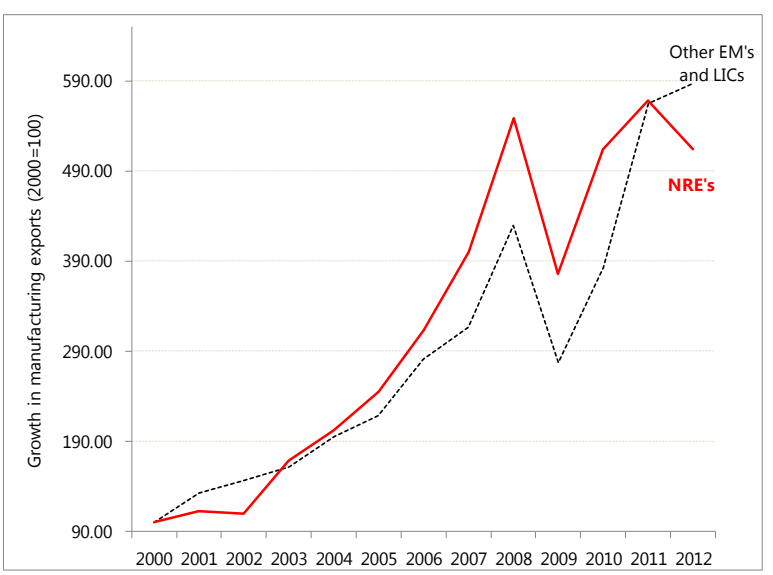
Merchandise Export Basket for NREs

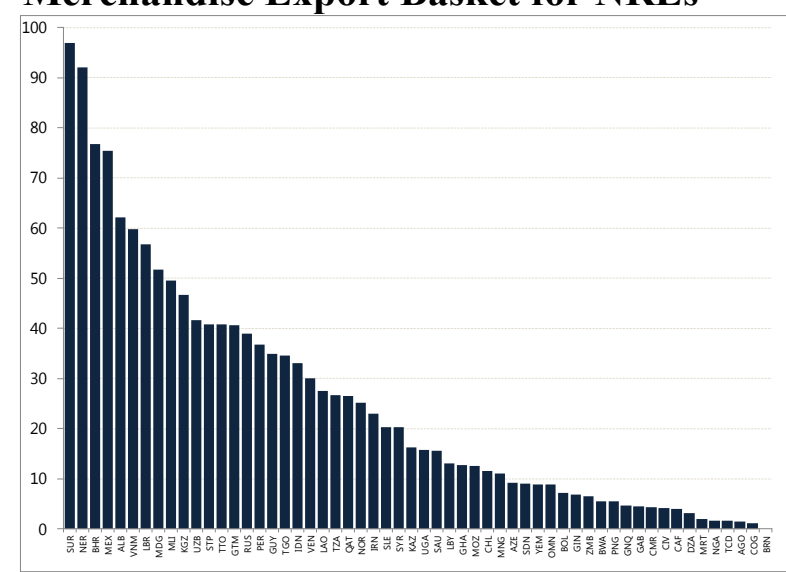

Source: Authors' calculations using WITS UN COMTRADE SITC Rev.3 three-digit level.

\footnotetext{
${ }^{13}$ On the contrary, the key driver for the increased tradability of services, including increased demand from NREs, is the revolution in information and communication technologies. Rapidly declining telecommunication costs, increasing Internet adoption around the world, and rapid proliferation of broadband Internet services have made arm's length delivery of services possible within and across borders. Using telecommunication networks, service products can be transported almost instantly over long distances (see Loungani and Mishra, 2014). The range of service activities that can be digitized and globalized is expanding, from the processing of insurance claims and tax payments to the transcription of medical records to the provision of education via online courses.

${ }^{14}$ For example, in 2013 manufacturing exports accounted for 90 percent of total exports in China, almost double the share during 1980-85.
} 
More than 99 percent of NREs have not diversified into manufacturing. In order to obtain a more country specific view of reallocation over in NREs, manufacturing exports are presented in more detail in Annex 3 Figure VI. The chart compares the types of the overall merchandise export basket in 1990 and 2010. The color code differentiates primary or resource based exports (light and dark grey) from more technology-skill intensive exports. The chart highlights that the majority of exports, over 90 percent NREs, are primary and resource based. With the exception of a few cases like Mexico, Vietnam, and Indonesia, almost 99 percent of exports from NREs are primary or resource based in nature. This is in contrast to non-NRE $\mathrm{s}$ where the share of high-tech and medium-tech manufacturing exports in total manufacturing exports has increased globally (particularly for fast growing economies in Asia). ${ }^{15}$

Within NREs, there has been a limited range of diversification success. Successful transformers like Indonesia, Vietnam, and Mexico have done better than others, because the realized growth is driven by productive capacity. These are the relatively good performers. The notion of good and bad cases can be measured more clearly from product and services that are exported. Some countries like Ecuador, Chile, Bolivia, Iran, and Kazakhstan also show some shifts into manufactured products. Looking at evidence over the past two decades, the rest aren't so lucky. The bad cases may be countries like Niger where almost all merchandise exports are uranium (for French nuclear plants), or oil in the case of Iraq.

Figure. 10. Composition of NREs Manufacturing Exports (\% of NRE Exports in manufacturing)

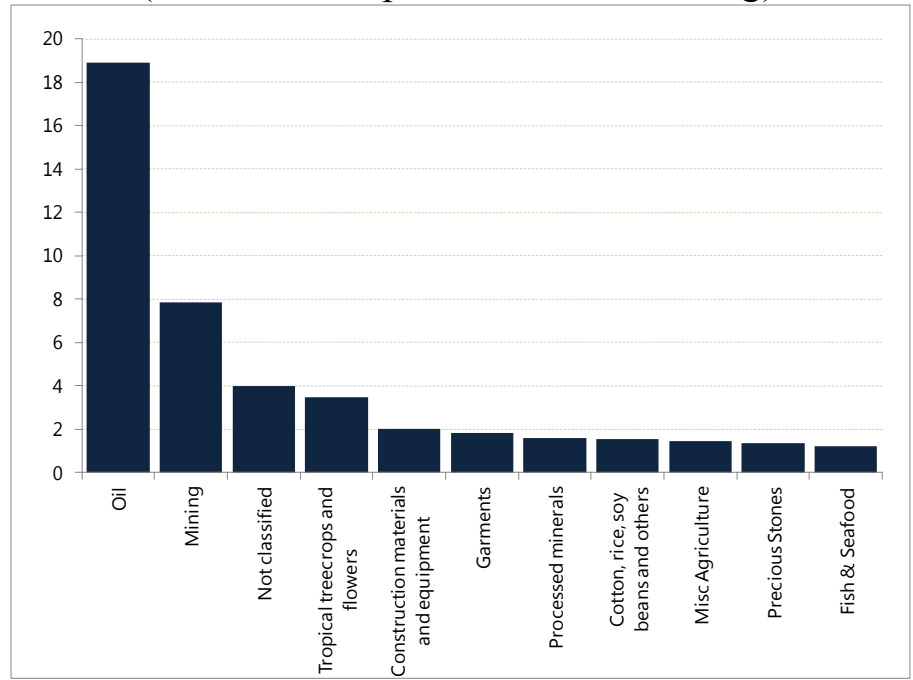

Source: Authors' calculations using WITS UN COMTRADE SITC Rev.3 three-digit level.

\footnotetext{
${ }^{15}$ For the definition of primary and resource based products and technology intensities used for splicing manufacturing data we use Lall's classification of exports. For details see Lall et al. (2005) and Lall (2000). Countries are classified into HIC, MIC, and LIC as per the classification scheme of the World Bank.
} 
More and more services can now be unbundled: a single service activity can be divided into tasks completed at different geographic locations. Adam Smith famously described how the productivity of a pin factory was boosted if, instead of one worker doing all the tasks involved in making a pin, a number of workers each specialized in particular tasks and then exchanged the fruits of their labor. A similar process of specialization and exchange is under way in many service industries. As with goods, services productivity can rise because of specialization (a finer division of labor) and scale (falling unit costs of production).

The unbundling of services has opened up niches that can be exploited by developing economies as well as advanced economies (see Loungani and Mishra, 2014; Mishra et al 2011). Though measuring services trade is difficult, it appears that developing economies' share in world service exports increased from about 14 percent in 1990 to 25 percent in 2011. Even though it is measured from a much lower base, service export growth has exceeded that from advanced economies.

NREs can trade modern services; especially in fragile events, services are traded across borders. Growth in service exports has been fast in NREs. We plot the aggregate growth in exporting services for NREs with other EMs and LICs in Annex 3 Figure VII Panel B. Service exports have grown four times since $2000 .{ }^{16}$ We index the year 2000 to 100 . In particular, high value digitally traded services are growing fast from NREs. Panel C plots the growth modern and traditional service exports from NREs. The primary source of aggregate growth in NREs service exports has been led by growth in traded information, business, marketing and financial services. ${ }^{17}$

Next, we benchmark export diversification in NREs against other countries. Annex 3 Figure VIII Panel A ranks countries concentration of their merchandise exports, using the Herfindahl index based on UNCTAD SITC Rev. 3 merchandise exports. The color codes identify the NREs against other countries. A lower number implies higher diversification; higher numbers signify relatively concentrated exports. A strong majority of NREs have more concentrated merchandise exports than the world average for 2007-12, with 10 of the top 12 most concentrated export baskets in the world. Turning to services, the story is more mixed. Panel B plots a similar ranking for service export diversification. Sample coverage is more limited, and the results show both highly concentrated NREs as well as NREs with relative diversification in service exports, particularly the larger countries.

16 The data used in exporting services is derived from Mishra (2015). The aggregate database excludes several NREs due to inconsistent reporting of the data. However, for several non-reported NREs there is indication of faster movements and reallocation with traded services. For list of countries used for traded services in NREs, please refer to Appendix.

\footnotetext{
${ }^{17}$ On average upper middle income NREs are growing fast in terms of modern service exports. There is some movement and stable growth in Sub-Saharan Africa LICs and lower MICs in low and medium tech manufacturing. However, there is not tremendous growth across the regions in NREs in manufacturing.
} 


\section{B. Quality and Complexity}

Quality management and quality assurance is critical for firms to be successful in the global market. Moreover, diversification is important to create new opportunities to upgrade (see Henn, Papageorgiou, and Spatafora, 2013). ${ }^{18}$

There are pockets of high quality products from the relatively developed NREs, but overall stagnant product quality improvements. Annex 3 Figure IX Panel A displays the quality of product exports from NRE sample at the 4-digit level in 2010 with other low and middle income countries. Panel A shows the specific products where NREs have quality close to world frontier. For each product line, the dot represents the low to high bounds of export quality frontier from the group of NREs or non-NREs. ${ }^{19}$ It shows that even in some products that NREs have high export quality, there is room to improve. Panel B shows the whole range of products comparing NREs range with non-NRE range. Overall ranges of NREs product specific exports are lower than comparable EMs and LICs. Panel C plots the median export quality across all NREs products at the 4-digit level in 1980 and 2010.

A new indicator called economic complexity index (ECI), developed by Hausmann et al (2011) and Simoes and Hidalgo (2011), is based on the underlying idea that countries differ in the amount of productive knowledge they hold, and so do products. It is a holistic measure that captures a country's productive knowledge and capabilities. The ECI combines metrics of the diversity of countries with the ubiquity of products. Countries that possess more knowledge have what it takes to produce a more diverse set of products. In other words, the amount of embedded knowledge that a country has is expressed in its productive diversity. Ubiquity is defined as the number of countries that make a product. The ubiquity of a product reveals information about the volume of knowledge that is required for its production. Complex products - those that require large productive knowledge-are less ubiquitous. Therefore, the amount of knowledge that a country has is expressed both in the diversity and ubiquity of the products that it makes. ${ }^{20}$

The overall complexity of exports from NREs has room to converge with the world frontier. Figure 11 displays the median economic complexity (for merchandise exports) measure

\footnotetext{
${ }^{18}$ Evidence suggest that quality upgrading is best encouraged through a broadly conducive domestic environment rather than sector-specific policies. High quality can exist in certain products either due to management practices, or utilization of unique resources for production of one-of the kind product, or resource that is unavailable in other locations.

${ }^{19}$ For example, electric railway locomotives those are of highest quality come from Mexico, and Russia. Whereas, many NREs are exporting high quality isotope compounds, concentrated ores, binoculars, gas turbines, natural rubber, diamonds, cotton, fabrics etc. Few products from NREs like coffee extracts, potassic salt, meat, potatoes, hemp, fish, etc. have moved closer to world quality frontiers. Miscellaneous manufactured articles, chemicals, machinery and transport equipment, crude materials, inedible, except fuels are generally of higher quality than the average NRE export basket. Mineral fuels, lubricants and related materials commodities and transactions are below NRE's average product quality.

${ }^{20}$ See Hausmann et al (2011) for details. A higher index suggests that a country is capable of producing a diverse range of products and products that are less ubiquitous than in other countries.
} 
for NREs with other regions. The complexity of NREs lags behind most countries in the world. Similarly, to document the complexity in service exports, we plot Panel B. The vertical axis is the ubiquity of a country's service exports, and the horizontal axis is the number of services exported by a country (or diversity). We highlight the specific NREs in our sample of service trade and provide the matrix of interpretation. While Kazakhstan is moving towards a diversified country exporting unique services, others like Mexico and Ecuador are non-diversified countries exporting standard services. Chile, Indonesia, others are also non-diversified service exporters but exporting more unique services. Overall, there is potential for NREs to expand exports and increase quality, diversity, and uniqueness of products and services for world markets.

Figure 11. Economic Complexity of Merchandise Exports

Panel A. Economic Complexity Index (Median), 2012

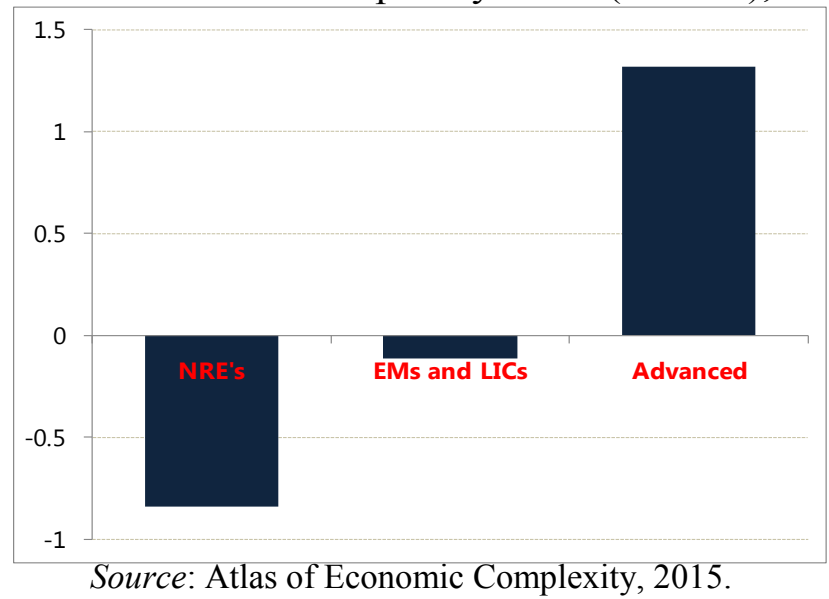

Panel B. Service Export Ubiquity vs. Diversity

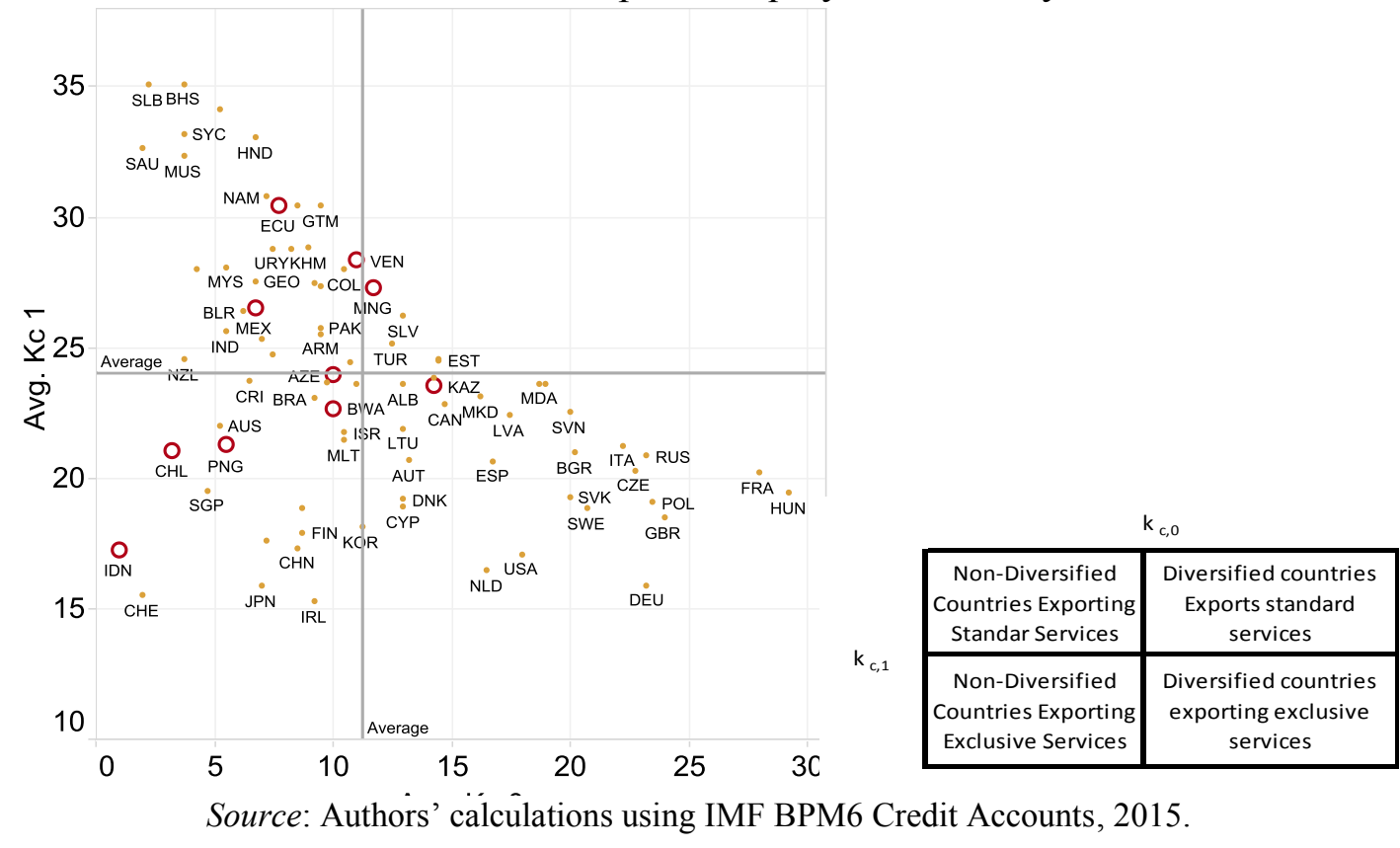




\section{Product Space and Specialization}

This section builds upon the earlier analysis on the evolution and composition of NRE exports, and looks at possible implications for future exports performance and growth. We use the product space and network approach. ${ }^{21}$ In this model of structural transformation, the 'product space' shows the changes in the revealed comparative advantage are governed by the pattern of relatedness of products at the global level (Hidalgo et al., 2007). As countries change their export mix, there is a strong tendency to move towards products that are more closely related to ones already being produced rather than to goods that are less closely related. In order to analyze future prospects of exports and growth performance, two notional variables "path" and "density" from the product space are used. ${ }^{22}$

Capabilities to produce competitive merchandise exports are lower in NREs compared to other countries at similar stages of development. Annex 3 Figure X compares the relative probability of having a comparative advantage among two export product groups using the density measure introduced in the product space approach. Panel A compares manufacturing exports for NREs with other developing countries for 2007-11. NREs are less likely to be competitive in each income group. Panel B similarly shows the average likelihood of comparative advantage for the export of primary and resource goods. Both charts highlight that NREs across all stages of development have relatively lower probability of having comparative advantage in both resource and manufacturing exports than other countries at similar stages of development.

Many NREs only export one resource good; others are more diversified. Annex 3 Figure XI shows the export basket for specific NREs, some more successful diversifiers than others. Panels A, B and C show the 2012 exports basket for Indonesia, Chile and Syria. Resource base exports are important for these countries; however there is considerable diversification in nonresource merchandise exports. Music equipment, foot-wear, garments, data processing machines etc., have been emerging new products from Indonesia and wine, fish, and copper wires from Chile. Panels D, E and F show the export baskets for Bolivia, Iraq and Mali. Each of these countries have more than 40 percent of their exports concentrated in a single non-renewable resource. These charts show the significant heterogeneity in diversification experience, and the tremendous room for growth for transformation of export baskets to higher value added and technology content exports.

\footnotetext{
${ }^{21}$ Specializing in some products will bring higher growth than specializing in others. Hausmann and Klinger (2006) and Hidalgo et al. (2007) show that it is much easier to produce a good that is "similar" to an already produced good.

${ }^{22}$ While path is a measure of the potential for future diversification, density is a measure of the ability of a country to take advantage of that potential. Formally, path is defined as the sum of all proximities between the respective product and all other products. A high value of path is indicative of products that are at the core of the product space and whose proximities with the rest of the nodes have larger values. A product with a longer path offers a better platform for further diversification than products at the periphery (with shorter paths). Density varies from 0 to 1 , with higher values indicating that the country has achieved comparative advantage in many nearby products, and therefore should be more likely to export that good in the future.
} 
Going forward, there is potential to build new comparative advantages based on the set of current specializations. ${ }^{23}$ Figure 12 shows the product space network map of merchandise exports in 2012 for the same group of six countries. ${ }^{24}$ Two observations are noteworthy. The number of products in which these economies have comparative advantage is not very concentrated at the core (except for Indonesia and Chile). Moreover, the network exhibits heterogeneity and a coreperiphery structure, as discussed above - the core of the network consists of metal products, machinery, and chemicals, whereas the periphery is formed by fishing, tropical, and cereal agriculture. Over time, the various varieties of apparels and textiles have led to comparative advantages in related products such as fabrics, leather, fashion, garment technology exports (green nodes). ${ }^{25}$ Economies like Syria are marginally diversify (even in products) and given initial capabilities have the potential to diversify more easily to sources of comparative advantage in several other products and services. Others like Iraq or Mali remain highly concentrated.

Adding a temporal analysis to the standard product space approach highlights examples where NREs have shown dynamic changes in competitiveness over time. On the basis of RCA time series data, product exports can be divided into four groups: classics, emerging, disappearing and marginal. ${ }^{26}$ Annex 3 Figure XII provides a graphical summary of NRE export baskets along these temporal groupings. Panel A shows the median and mean shares of exports in each of the four groupings, for resource-based exports and manufacturing exports, while Panels B and C provide a further breakdown by country. We rank the sample of 40 NREs by the countries' exporting most products. It is evident excluding the top 5 from each sample leaves all the remaining economies with over 90 percent of products remaining marginal. However, there are few emerging small players. Panel D shows the economies against category of services. If the country has an emerging RCA in that service, it identifies the country and the service. Examples include Mongolia's emerging comparative advantage in agriculture, mining, and on site processing services for green and renewable energies, Guinea' growing diversity in exporting

\footnotetext{
${ }^{23}$ Hausmann and Klinger (2006) show that this measure of density is indeed a highly significant in predicting how a country's productive structure will shift over time: countries are much more likely to move to products that have a higher density, or are closer to their current production.

${ }^{24}$ We use the product space network to study the evolution of productive structure by observing the location of products in which NREs has revealed comparative advantage (RCA $>1$, defined earlier) in two different time periods.

${ }^{25}$ Potential sources of new comparative advantages are visible at the core of Chile and Indonesia's product space, where a large number of high value products are closely (i.e., require similar capabilities to produce). However, for many products in the core of the product space network, entry costs for developed countries are low and those products are likely to be exported by many countries or by large countries, such as China, Europe, or the USA. Thus, diversification strategies may differ depending on existing capabilities, market access prospects, robustness of the private sector, etc...

26 "Classics" are products with demonstrated competitiveness over time (i.e., RCA $>1$ ). "Emerging champions" are products that have more recently become competitive. They show promise and could be targeted for increased production or higher value production, given their ability to emerge in the competitive environment of the global market and within the challenges of a resource-rich economy. "Disappearances" are products that have lost competitiveness, while "marginals" have not been exported competitively over the time series coverage.
} 
health care expenditure services, to architectural and engineering services, business travel service from Azerbaijan, and health related service from Algeria, Cameroon, Guyana. Chile is a growing hub of banking and financial service acquisitions across the Latin America.

\section{Figure 12. Product Space Representation of Selected NREs 2012}

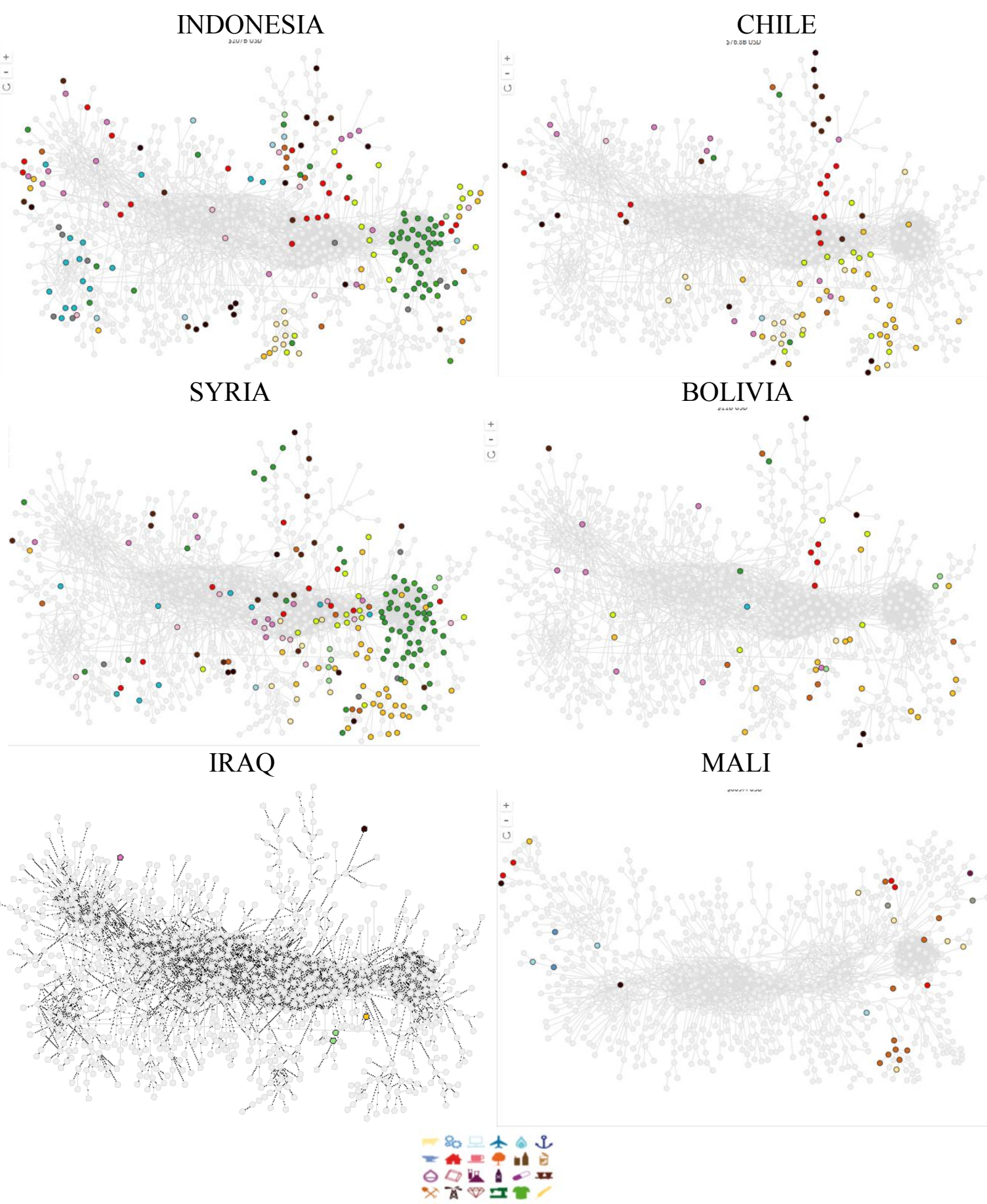


Table 3. Top 80 products with emerging comparative advantage from NREs (ranked by product complexity)

\begin{tabular}{|c|c|c|c|c|c|c|c|c|c|c|}
\hline code & product & product_name & tech & community & $\begin{array}{c}\text { product } \\
\text { complexity }\end{array}$ & $\begin{array}{l}\text { income level } \\
\text { associated with } \\
\text { product } \\
\text { (PRODY) }\end{array}$ & $\begin{array}{l}\text { Path } \\
2007-11\end{array}$ & $\begin{array}{c}\text { Share in } \\
\text { Merchandise } \\
\text { expoets 2007- } \\
11 \text { (avg) }\end{array}$ & $\begin{array}{l}\text { density } \\
2012\end{array}$ & income \\
\hline$\overline{M E X}$ & 7432 & Parts, nes of the pumps and compressor falling within heading 7431 & MT3 & Machinery & 1.6 & 22133.0 & 153.9 & 0.2 & 0.23652 Latin America \& Caribbean & Upper middle income \\
\hline MEX & 7138 & Internal combustion piston engines, nes & МТз & Machinery & 1.5 & 22899.6 & 123.5 & 0.1 & 0.23476 Latin America \& Caribbean & Upper middle income \\
\hline MEX & 7421 & Reciprocating pumps (other than those of heading 74281) & МТз & Electronics & 1.4 & 20182.4 & 126.8 & 0.2 & 0.24788 Latin America \& Caribbean & Upper middle income \\
\hline MEX & 7523 & Complete digital central processing units; digital processors & HT1 & Electronics & 1.3 & 24707.2 & 91.2 & 2.2 & 0.26516 Latin America \& Caribbean & Upper middle income \\
\hline MEX & 6632 & Abrasive power or grain, on a base of woven fabrics & RB2 & Machinery & 1.1 & 23134.6 & 170.6 & 0.0 & 0.23368 Latin America \& Caribbean & Upper middle income \\
\hline MEX & 7239 & Parts, nes of machinery and equipment of headings 72341 to 72346 & МТз & Machinery & 1.1 & 20784.5 & 144.7 & 0.6 & 0.24144 Latin America \& Caribbean & Upper middle income \\
\hline MEX & 7431 & Air pumps, vacuum pumps and air or gas compressors & Мтз & Machinery & 1.1 & 20846.9 & 163.9 & 0.3 & 0.24278 Latin America \& Caribbean & Upper middle income \\
\hline MEX & 6637 & Refractory goods, nes & RB2 & Electronics & 1.0 & 21194.7 & 119.0 & 0.0 & 0.2414 Latin America \& Caribbean & Upper middle income \\
\hline MEX & 5843 & Cellulose acetates & MT2 & Chemicals and health related products & 1.0 & 24531.5 & 43.5 & 0.0 & 0.33396 Latin America \& Caribbean & Upper middle income \\
\hline VNM & 6648 & Glass mirror, unframed, framed or backed & RB2 & Electronics & 1.0 & 19153.2 & 160.1 & 0.1 & 0.22295 East Asia \& Pacific & Lower middle income \\
\hline VNM & 7712 & Other electric power machinery, parts, nes & HT1 & Electronics & 0.9 & 18675.4 & 146.1 & 0.4 & 0.23566 East Asia \& Pacific & Lower middle income \\
\hline UZB & 7810 & Passenger motor vehicles (excluding buses) & MT1 & Machinery & 0.9 & $\begin{array}{l}22631.4 \\
2261.4\end{array}$ & 163.9 & 9.6 & 0.10411 Europe \& Central Asia & Lower middle income \\
\hline VNM & 7853 & Invalid carriages; parts, nes of articles of heading 785 & MT1 & Not classified & 0.9 & 19450.7 & 135.0 & 0.2 & 0.26665 East Asia \& Pacific & Lower middle income \\
\hline MEX & 8852 & Clocks, clock movements and parts & Мтз & Electronics & 0.8 & 18700.1 & 96.8 & 0.0 & 0.25297 Latin America \& Caribbean & Upper middle income \\
\hline IDN & 6639 & Articles of ceramic materials, nes & RB2 & Not classified & 0.8 & 17121.1 & 120.8 & 0.1 & 0.23733 East Asia \& Pacific & Lower middle income \\
\hline IDN & 7782 & Electric filament lamps and discharge lamps; arc-lamps & HT1 & Boilers & 0.8 & 15688.8 & 128.8 & 0.1 & 0.22108 East Asia \& Pacific & Lower middle income \\
\hline VNM & 7161 & Motors and generators, direct current & HT1 & Machinery & 0.8 & 23424.9 & 149.6 & 0.2 & 0.22035 East Asia \& Pacific & Lower middle income \\
\hline MEX & 7915 & Railway and tramway freight, etc, not mechanically propelled & MT2 & Ships & 0.8 & 11785.0 & 121.8 & 0.2 & 0.25349 Latin America \& Caribbean & Upper middle income \\
\hline VNM & 8811 & $\begin{array}{l}\text { Photographic cameras, flashlight apparatus, parts, accesssories, nes } \\
\text { Pally }\end{array}$ & HT2 & $\begin{array}{l}\text { Electronics } \\
\text { Elas }\end{array}$ & 0.7 & $\begin{array}{l}118273.9 \\
13273.9\end{array}$ & 128.5 & 0.5 & 0.22066 East Asia \& Pacific & Lower middle income \\
\hline LAO & 8951 & Office and stationary supplies, of base metal & LT2 & Home and office products & 0.7 & 17390.6 & 136.9 & 0.0 & 0.08022 East Asia \& Pacific & Lower middle income \\
\hline MEX & 7628 & Other radio receivers & МТ3 & Electronics & 0.7 & 18821.8 & 72.3 & 0.1 & 0.25343 Latin America \& Caribbean & Upper middle income \\
\hline MEX & 7648 & Telecommunications equipment, nes & $\mathrm{HT} 1$ & Electronics & 0.7 & 21949.6 & 127.8 & 0.2 & 0.22851 Latin America \& Caribbean & Upper middle income \\
\hline RUS & 7144 & Reaction engines & МТз & Aircraft & 0.7 & 23330.6 & 98.8 & 0.2 & 0.12278 High Income & High income: nonOECD \\
\hline LBR & 2331 & Synthetic rubber, latex; factice derived from oils & RB1 & Chemicals and health related products & 0.6 & 18232.8 & 118.8 & 0.3 & 0.03241 Sub-Saharan Africa & Low income \\
\hline VNM & 7642 & Microphones; loud-speakers; audio-frequency electric amplifiers & HT1 & Electronics & 0.6 & $\begin{array}{l}173734.1 \\
1730\end{array}$ & 1121.2 & 0.2 & 0.26447 East Asia \& Pacific & Lower middle income \\
\hline MEX & 7832 & Road tractors for semi-trailers & MT1 & Machinery & 0.6 & 22446.5 & 134.4 & 0.9 & 0.22514 Latin America \& Caribbean & Upper middle income \\
\hline MEX & 7622 & Portable radio receivers & МТз & Electronics & 0.6 & 16125.5 & 89.5 & 0.1 & 0.27068 Latin America \& Caribbean & Upper middle income \\
\hline CHL & 114 & Poultry, dead and edible offal, fresh, chilled or frozen & $\mathrm{PP}$ & Meat and eggs & 0.6 & 16998.9 & 134.7 & 0.3 & 0.14361 High Income & High income: $\mathrm{OECD}$ \\
\hline VNM & 6517 & Yarn of regenerated fibres, not for retail, monofil, strip, etc & LT1 & Textile \& Fabrics & 0.5 & 10893.3 & 165.5 & 0.1 & 0.30686 East Asia \& Pacific & Lower middle income \\
\hline MEX & 6422 & Correspondence stationary & LT2 & Construction materials and equipment & 0.4 & 15644.6 & 169.8 & 0.0 & 0.23392 Latin America \& Caribbean & Upper middle income \\
\hline MEX & 6793 & Steel and iron forging and stampings, in the rough state & LT2 & Machinery & 0.4 & 18742.4 & 154.3 & 0.1 & 0.24129 Latin America \& Caribbean & Upper middle income \\
\hline IDN & 6872 & Tin and tin alloys worked & $\mathrm{PP}$ & $\begin{array}{l}\text { Processed minerals } \\
\text { Poctions }\end{array}$ & 0.4 & 15453.6 & $\begin{array}{l}154.3 \\
105.9\end{array}$ & 0.0 & 0.25085 East Asia \& Pacific & Lower middle income \\
\hline MEX & 6872 & Tin and tin alloys worked & PP & Processed minerals & 0.4 & 15453.6 & 105.9 & 0.0 & 0.24695 Latin America \& Caribbean & Upper middle income \\
\hline VNM & 6351 & Wood packing cases, boxes, cases, crates, etc, complete & RB1 & Construction materials and equipment & 0.4 & 21600.8 & 177.1 & 0.0 & 0.24964 East Asia \& Pacific & Lower middle income \\
\hline ECU & 7821 & Motor vehicles for the transport of goods or materials & MT1 & Machinery & 0.3 & 19327.3 & 164.7 & 0.9 & 0.09238 Latin America \& Caribbean & Upper middle income \\
\hline VNM & 6960 & Cuttery & LT2 & Home and office & 0.3 & 15859.2 & 132.2 & 0.2 & 0.2545 East Asia \& Pacific & Lower middle income \\
\hline ECU & 6343 & Improved wood and reconstituted wood & RB1 & Construction materials and equipment & 0.3 & 19065.5 & 171.6 & 0.2 & 0.10968 Latin America \& Caribbean & Upper middle income \\
\hline UZB & 5831 & 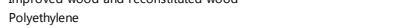 & MT2 & Petrochemicals & 0.3 & 22261.6 & 158.5 & 1.3 & 0.11586 Europe \& Central Asia & Lower middle income \\
\hline UZB & 7711 & Transformers, electrical & HT1 & Boilers & 0.3 & 15683.6 & 163.4 & 0.3 & 0.11692 Europe $\&$ Central Asia & Lower middle income \\
\hline IDN & 6822 & Copper and copper alloys, worked & $\mathrm{PP}$ & Metal products & 0.2 & 16821.6 & 155.9 & 0.5 & 0.22626 East Asia \& Pacific & Lower middle income \\
\hline RUS & $\begin{array}{l}6822 \\
6822\end{array}$ & Copper and copper alloys, worked & $\mathrm{PP}$ & Metal products & 0.2 & $\begin{array}{l}108821.6 \\
16821.6\end{array}$ & 155.9 & 0.6 & 0.08858 High Income & High income: nonOECD \\
\hline IDN & 2665 & Discontinuous synthetic fibres, not carded or combed & MT2 & Not classified & 0.2 & 15100.8 & 137.4 & 0.1 & 0.27924 East Asia \& Pacific & Lower middle income \\
\hline VNM & 2665 & Discontinuous synthetic fibres, not carded or combed & MT2 & Not classified & 0.2 & 15100.8 & 137.4 & 0.1 & 0.2911 East Asia \& Pacific & Lower middle income \\
\hline VNM & 7641 & Electrical line telephonic and telegraphic apparatus & HT1 & Electronics & 0.2 & 18480.1 & 115.1 & 0.5 & 0.24765 East Asia \& Pacific & Lower middle income \\
\hline VNM & 6259 & Other tires, tire cases, tire flaps and inner tubes, etc & RB1 & Boilers & 0.2 & 13823.0 & 155.6 & 0.1 & 0.26655 East Asia \& Pacific & Lower middle income \\
\hline IDN & 7852 & Cycles, not motorized & MT1 & Home and office products & 0.2 & 11019.7 & 139.4 & 0.1 & 0.24568 East Asia \& Pacific & Lower middle income \\
\hline TKM & 5832 & Polypropylene & MT2 & Petrochemicals & 0.2 & 16540.6 & 162.6 & 1.7 & 0.0438 Europe $\&$ Central Asia & Upper middle income \\
\hline MEX & 6519 & Yarn of textile fibres, nes & LT1 & Textile \& Fabrics & 0.1 & 16233.8 & 145.3 & 0.0 & 0.23362 Latin America \& Caribbean & Upper middle income \\
\hline MEX & 8924 & Picture postcards, decalcomanias, etc, printed & & Not classified & 0.1 & 17499.3 & 116.7 & 0.0 & 0.22632 Latin America \& Caribbean & Upper middle income \\
\hline RUS & 5233 & Salts of metallic acids; compounds of precious metals & $\mathrm{RB} 2$ & Chemicals and health related products & 0.1 & 23693.7 & 113.2 & 0.2 & 0.10211 High Income & High income: nonOECD \\
\hline LAO & 2471 & Sawlogs and veneer logs, of coniferous species & RB1 & Construction materials and equipment & 0.1 & 19965.7 & 135.7 & 0.2 & 0.09762 East Asia \& Pacific & Lower middle income \\
\hline VNM & 6514 & Yarn $85 \%$ of synthetic fibres, not for retail; monofil, strip, etc & LT1 & Textile \& Fabrics & 0.1 & 10573.4 & 148.0 & 0.4 & 0.30343 East Asia \& Pacific & Lower middle income \\
\hline MEX & 5224 & Metallic oxides of zinc, iron, lead, chromium etc & RB2 & Metal products & 0.1 & 14727.6 & 143.5 & 0.0 & 0.23121 Latin America \& Caribbean & Upper middle income \\
\hline IDN & 2332 & Reclaimed rubber, waste, scrap of unhardened rubber & RB1 & Petrochemicals & 0.0 & 15786.0 & 151.9 & 0.0 & 0.25466 East Asia \& Pacific & Lower middle income \\
\hline LAO & 3510 & Electric current & & Construction materials and equipment & 0.0 & 8981.1 & 154.5 & 11.3 & 0.10987 East Asia \& Pacific & Lower middle income \\
\hline VNM & 6112 & Composition leather, in slabs, sheets or rolls & LT1 & Not classified & 0.0 & 10395.6 & 109.5 & 0.0 & 0.22036 East Asia \& Pacific & Lower middle income \\
\hline RUS & 6618 & Construction materials, of asbestos-cement or fibre-cements, etc & RB2 & Construction materials and equipment & 0.0 & 13092.8 & 162.3 & 0.0 & 0.08909 High Income & High income: nOnOECD \\
\hline MNG & 6594 & Carpets, rugs, mats, of wool or fine animal hair & LT1 & Garments & 0.0 & 9884.0 & 147.4 & 0.0 & 0.04928 East Asia \& Pacific & Lower middle income \\
\hline VNM & 8933 & Personal adornments and ornaments articles of plastic & LT2 & Home and office products & 0.0 & 11281.3 & 44.3 & 0.0 & 0.40852 East Asia \& Pacific & Lower middle income \\
\hline VNM & 8973 & Precious jewellery, goldsmiths' or siversmiths' wares & LT2 & Mining & 0.0 & 14248.9 & 117.9 & 2.1 & 0.29113 East Asia \& Pacific & Lower middle income \\
\hline MEX & 484 & Bakery products & RB1 & Food Processing & 0.0 & 14329.3 & 158.0 & 0.2 & 0.23584 Latin America \& Caribbean & Upper middle income \\
\hline VNM & 6531 & Fabrics, woven, of continuous synthetic textile materials & MT2 & Textile \& Fabrics & -0.1 & 21997.4 & 133.8 & 0.5 & 0.30844 East Asia \& Pacific & Lower middle income \\
\hline YEM & 230 & 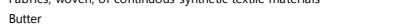 & RB1 & Milk \& cheese & -0.1 & 21731.1 & 137.4 & 0.1 & 0.06735 Middle East \& North Africa & Lower middle income \\
\hline DZA & 5114 & Hydrocarbons derivatives, nonhaloganeted & RB2 & Agrochemicals & -0.1 & 13686.2 & 153.6 & 0.0 & 0.02239 Middle East \& North Africa & Upper middle income \\
\hline UZB & 6130 & Furskins, tanned or dressed; pieces of furskin, tanned or dressed & LT1 & Meat and eggs & -0.1 & 17822.6 & 156.4 & 0.0 & 0.13094 Europe \& Central Asia & Lower middle income \\
\hline $\mathrm{CHL}$ & 452 & Oats, unmilled & PP & Misc Agriculture & -0.1 & 26454.6 & 92.7 & 0.0 & 0.15722 High Income & High income: OECD \\
\hline UZB & 6651 & Bottles etc of glass & LT2 & Not classified & -0.1 & 9251.2 & 149.8 & 0.2 & 0.126 Europe \& Central Asia & Lower middle income \\
\hline VNM & 6666 & Ornaments, personal articles of porcelain, china, or ceramic, nes & LT2 & Home and office products & -0.1 & 12505.7 & 109.8 & 0.1 & 0.34106 East Asia \& Pacific & Lower middle income \\
\hline YEM & 3352 & Mineral tars and products & RB2 & Agrochemicals & -0.1 & 16213.0 & 152.2 & 1.3 & 0.06385 Middle East \& North Africa & Lower middle income \\
\hline IDN & 8481 & Articles of apparel, clothing accessories of leather & $\begin{array}{l}\text { REL } \\
\text { LT1 } 19\end{array}$ & $\begin{array}{l}\text { Aromeremic } \\
\text { Garments }\end{array}$ & $\begin{array}{l}-0.1 \\
-0.1\end{array}$ & $\begin{array}{l}802310.6 \\
8382.6\end{array}$ & 144.4 & 0.1 & 0.27607 East Asia \& Pacific & Lower middle income \\
\hline MEX & 6129 & Other articles of leather or of composition leather & LT1 & Leather & -0.1 & 12281.0 & 159.7 & 0.0 & 0.24526 Latin America \& Caribbean & Upper middle income \\
\hline VNM & 8481 & Articles of apparel, clothing accessories of leather & LT1 & Garments & -0.1 & 8382.6 & 144.4 & 0.1 & 0.32682 East Asia \& Pacific & Lower middle income \\
\hline IDN & 712 & Coffee extracts, essences or concentrates & $\mathrm{PP}$ & Agrochemicals & -0.2 & 10918.0 & 146.6 & 0.1 & 0.24718 East Asia \& Pacific & Lower middle income \\
\hline MEX & 712 & Coffee extracts, essences or concentrates & PP & Agrochemicals & -0.2 & 10918.0 & 146.6 & 0.0 & 0.24764 Latin America \& Caribbean & Upper middle income \\
\hline VNM & 8122 & Ceramic plumbing fixtures & МТз & Construction materials and equipment & -0.2 & 12991.6 & 165.7 & 0.1 & 0.28281 East Asia \& Pacific & Lower middle income \\
\hline IDN & 6532 & Fabrics, woven, $85 \%$ plus of disconti & MT2 & Textile \& Fabrics & -0.2 & 11471.1 & 147.7 & 0.0 & 0.26344 East Asi & Lower middle income \\
\hline VNM & 6552 & Knitted, not elastic nor rubberized, of fibres other than synthetic & LT1 & Garments & -0.2 & 14411.2 & 112.9 & 0.2 & 0.32897 East Asia \& Pacific & Lower middle income \\
\hline MEX & 6951 & Hand tools, used in agriculture, horticulture or forestry & LT2 & Not classified & -0.2 & 11293.0 & 134.5 & 0.0 & 0.23991 Latin America \& Caribbean & Upper middle income \\
\hline VNM & 6974 & Base metal domestic articles, nes, and parts thereof, nes & LT2 & Home and office products & -0.2 & 11767.5 & 148.7 & 0.1 & 0.29667 East Asia \& Pacific & Lower middle income \\
\hline UZB & 2519 & Other cellulosic pulps & RB1 & Pulp and paper & -0.2 & 17350.1 & 93.8 & 0.1 & 0.11789 Europe \& Central Asia & Lower middle income \\
\hline AZE & 574 & Apples, fresh & $\mathrm{PP}$ & Fruit & -0.3 & 9525.1 & 148.6 & 0.1 & 0.04155 Europe $\&$ Central Asia & Upper middle income \\
\hline
\end{tabular}

Source: Authors' calculations using UN COMTRADE SITC Rev. 3 from WITS. 
Table 4. NRE Service Exports: Change in Revealed Comparative Advantage 2000-13 (average across NREs)

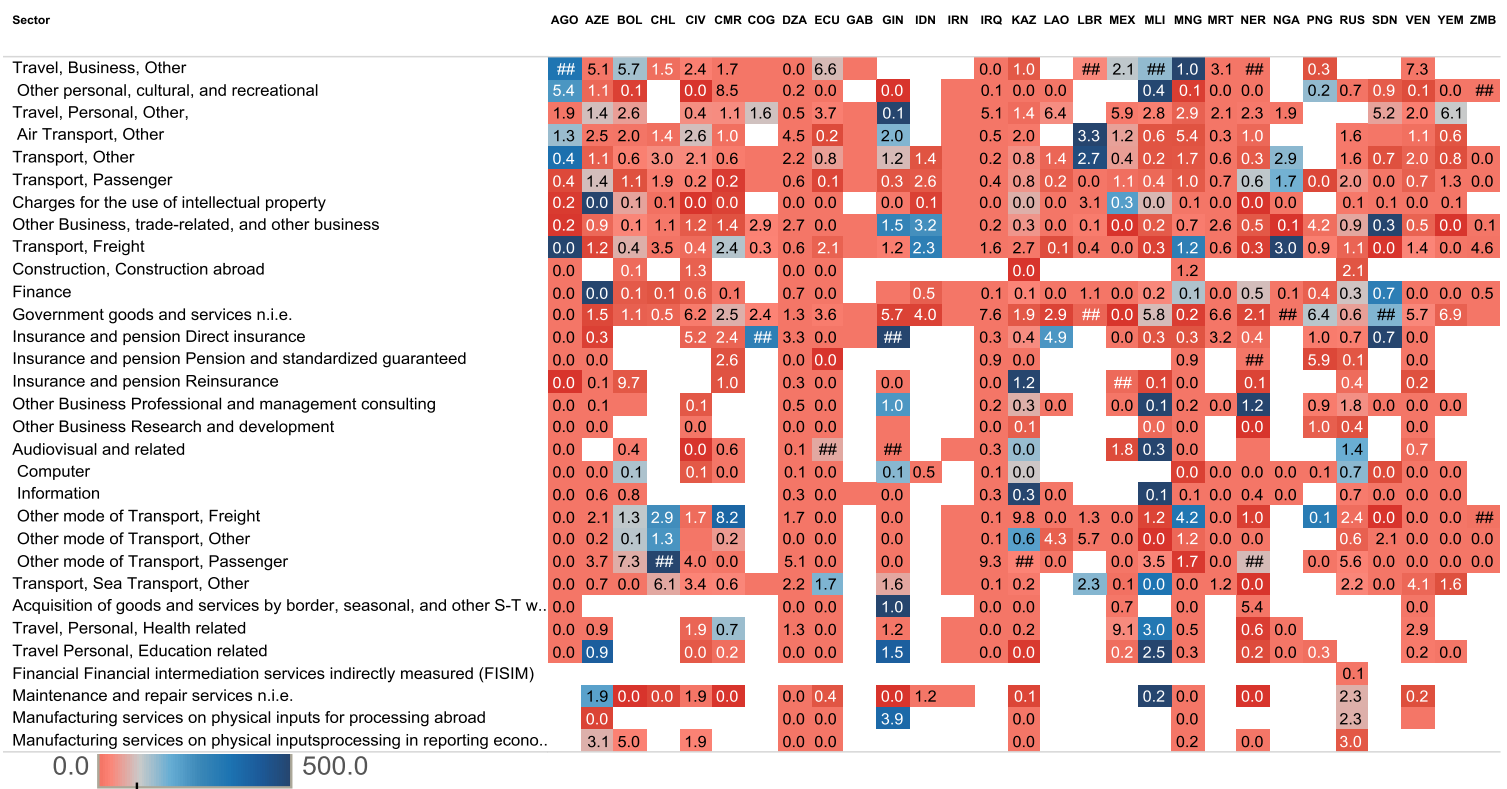

Notes: The chart maps the change in revealed comparative advantage (RCA). The color of the square represents the change in RCA between 2000 and 2013. Light blue is a moderate increase and dark blue is a large increase. The number in each square indicates the 2007-11 average RCA level (where RCA $>=1$ implies comparative advantage in exporting that particular service). 


\section{CONCluding Remarks}

Empirical analysis of economic transformation in NREs is limited. This paper provides important benchmarks for these countries along key growth-related dimensions, showing how output, productivity, and export baskets have evolved over time for NREs relative to other developing countries. The analysis is particularly useful given the large degree of heterogeneity in both resource dependency and associated economic outcomes. This heterogeneity is evident in the volatile relationship between resource sector growth and overall gross value added in the economy. Benchmarks in productivity growth and trade sophistication show the difficulty many countries have faced in breaking the reliance on exhaustible resources. For the bulk of NREs, inter-sectoral growth dynamics are relatively more subdued, and productivity growth is lagging behind other countries, even after controlling for similar levels of development. Product exports remain stubbornly concentrated at the low end of technological sophistication, with few examples of successful diversification from mining and consumption-based services. An encouraging finding of the analysis is the increasingly diversified service export baskets in some NREs, which offers a potential channel for future growth.

The paper points to several areas for further work to better understand resource-led growth dynamics. There is considerable scope to look more closely at the role of service sector growth in resource booms. Impressive service sector growth may easily be mistaken for new sustainable growth poles when service demand is heavily driven by the consumption of resource rents. Economic vulnerability may have actually increased as opposed to a structural improvement. Unfortunately many NREs have limited data on formal service sector activities, and little if any coverage of informal activities. More work is needed to improve service sector data and disentangle consumption-based demand from improved supply of more durable sources of future growth. Additional work could also help to better understand the lack of productivity growth in NREs. Firm-level data in NREs could be particularly useful in identifying the underlying factors in our cross-country results. More broadly, political risks, rule of law, and internal conflict can easily distort the reality of modernizing these resource-dependent economies. A more in-depth case study approach could help in these areas. 


\section{REFERENCES}

Acemoglu, D. and D. Autor, (2011), "Skills, Tasks and Technologies: Implications for Employment and Earnings", in Handbook of Labor Economics, 4: 1043-1171.

Anand, R., S. Mishra and N. Spatafora, (2012), "Structural Transformation and the Sophistication of Production", IMF Working Paper No. 1249.

Amiti, M. and C. Freund, (2008), “The Anatomy of China's Export Growth”. World Bank Policy Research Working Paper, No.4628.

Arnold, J. and B. Javorcik, M. Lipscomb and A. Mattoo, (2012), "Services Reform and Manufacturing Performance : Evidence from India," Policy Research Working Paper Series 5948, World Bank.

Atkinson, A. and J. Stiglitz, (1969), "A New View of Technological Change”, The Economic Journal 79, 573-578.

Battaile, B., R. Chisik, and H. Onder, (2014), "Service, Inequality, and the Dutch Disease". World Bank Policy Research Working Paper No. 6966.

Battaile, B. and A. Villareal, (2014), "Service Sector Growth Decomposition for ResourceRich Countries", PRMED Note, World Bank.

Bosworth, B. and J. Triplett, (2007), "Is the 21st Century Productivity Expansion Still in Services? And What Should Be Done About It?” Brookings Institution.

Cadot, O., C. Carrère and V. Strauss-Kahn, (2013), "Trade Diversification, Income, And Growth: What Do We Know?" Journal of Economic Surveys, Wiley Blackwell, vol. 27(4), pages 790-812, 09.

Dabla-Norris, E., G. Ho, K. Kochhar, A. Kyobe, and R. Tchaidze, (2013), “Anchoring Growth: The Importance of Productivity-Enhancing Reforms in Dabla-Norris, Era, Alun Thomas, Rodrigo Garcia-Verdu, and Yingyuan Chen, (2013). "Benchmarking Structural Transformation across the World," IMF Working Paper 13/176 (Washington: International Monetary Fund).

Dervis, K., (2012), Convergence, Interdependence, and Divergence, Brookings

Desmet, K. and E. Rossi-Hansberg (2009), "Spatial Growth and Industry Age", Journal of Economic Theory, 144:2477-2502.

Eichengreen, B. and P. Gupta (2013), "The Two Waves of Service-Sector Growth.” Oxford Economic Papers 65(1): 96-123. 
Flaaen A., E. Ghani and S. Mishra, (2013), "How to Avoid Middle Income Traps? Evidence from Malaysia", Policy Research Working Paper Series 6427, World Bank

Frankel, J., (2011), "The Natural Resource Curse: A Survey of Diagnoses and Some Prescriptions.” Paper for the IMF High Level Seminar on Commodity Price Volatility and Inclusive Growth in Low-Income Countries, Washington DC, September 2011.

Gelb, A., (2010), "Economic Diversification in Resource Rich Countries”, Center for Global Development, Washington DC.

Gelb A., C. Meyer and V. Ramachandran, (2014), "Development as Diffusion: Manufacturing Productivity and Sub-Saharan Africa's Missing Middle," Center for Global Development, Working Paper No. 357.

Ghani E., A. Goswami and H. Kharas, (2011), "Can Services be the Next Growth Escalator?", VoxEU.org, 12 December.

Hausmann, R., D. Rodrik and A. Velasco, (2008), "Growth Diagnostics," in The Washington Consensus Reconsidered: Towards a New Global Governance, ed. by J. Stiglitz and N. Serra, (New York, New York: Oxford University Press).

Hausmann, R. and Hidalgo, C.A. (forthcoming), "The Network Structure of Economic Output" Forthcoming in Journal of Economic Growth.

Hausmann, R, and B. Klinger, (2006), "Structural Transformation and Patterns of Comparative Advantage in the Product Space," CID Working Paper No. 128. Kennedy School of Government, Harvard University.

Hausmann, R., C. Hidalgo, S. Bustos, M. Coscia, S. Chung, J. Jimenez, A. Simoes, and M. Yildirim, (2011), "The Atlas of Economic Complexity", Puritan Press, Cambridge MA.

Helpman, E., (1993), “Innovation, Imitation, and Intellectual Property Rights.” Econometrica, Vol. 60(6): 1247-1280.

Helpman, E, (2004), “The Mystery of Economic Growth.” Cambridge, Belknap Press of Harvard University Press.

Helpman, E., M. Melitz, and Y. Rubinstein, (2008), "Estimating Trade Flows: Trading Partners and Trading Volumes", The Quarterly Journal of Economics", Vol. 123(2): 441-487.

Helpman, E., and O. Itskhoki (2010), "Labour Market Rigidities, Trade and Unemployment," Review of Economic Studies, 77(3), 11001137. 
Helpman, E., O. Itskhoki, and S. Redding, (2010), "Inequality and Unemployment in a Global Economy," Econometrica, 78(4), 1239-1283.

Henn, C., C. Papageorgiou and N. Spatafora, (2013). "Export Quality in Developing Countries," IMF Working Papers 13/108, International Monetary Fund.

Henn, C. and C. Papageorgiou and N. Spatafora, (2015). "Export quality in advanced and developing economies: Evidence from a new dataset," WTO Staff Working Papers ERSD-2015-02, World Trade Organization (WTO), Economic Research and Statistics Division.

Hidalgo, C., B. Klinger, A. Barabási, R. Hausmann, (2007). "The Product Space Conditions the Development of Nations", Science 317 (5837), 482-487 (New York, N.Y.).

Hidalgo, C. and R. Hausmann, (2009), “The Building Blocks of Economic Complexity," Proceedings of the National Academy of Sciences 106, 10570-10575 (2009).

Hummels, D. and P. Klenow, (2005), 'The Variety and Quality of a Nation's Export', American Economic Review, 95, 3, 704-723.

Imbs, Jean, and R. Wacziarg, (2003), "Stages of Diversification”, American Economic Review 93, 63-86.

International Monetary Fund, (2012), "Macroeconomic Policy Frameworks for Resource-Rich Developing Countries," August 24, 2012, (www.imf.org/external/np/pp/eng/ 2012/082412a.pdf).

International Monetary Fund, (2014), “Anchoring Growth: The Importance of Productivity Enhancing Reforms", Staff Discussion Note.

International Monetary Fund, (2014), Direction of Trade Statistics.

International Monetary Fund, (2015), Balance of Payment Statistics, BPM5 Dataset.

International Monetary Fund, (2015), Balance of Payment Statistics, BPM6 Working Dataset.

Javorcik, B. and Y. Li, (2008), "Do the Biggest Aisles Serve a Brighter Future? Global Retail Chains and Their Implications for Romania," CEPR Discussion Papers No. 6906.

Koren, M. and S. Tenreyro, (2007), "Volatility and Development". Quarterly Journal of Economics. Volume 122 pp. 243-87. 
Krugman, P., (1979), “A Model of Innovation, Technology Transfer, and the World Distribution of Income", Journal of International Economics, Vol. 9(4): 369-382.

Krugman, P. (1980), 'Scale Economies, Product Differentiation, and the Pattern of Trade', American Economic Review, 70, 950-959.

Kuralbayeva, K., and R. Stefanski, (2013), "Windfalls, Structural Transformation and Specialization", OxCarre Research Paper 54, Department of Economics, University of Oxford.

Lall, S., (2000). "The Technological Structure and Performance of Developing Country Manufactured Exports, 1985-98," Oxford Development Studies 28(3).

Lall, S., J. Weiss, and J. Zhang, (2005), “The 'Sophistication' of Exports: A New Measure of Product Characteristics," Queen Elizabeth House Working Paper 123, Oxford University.

Lederman, D. and W. Maloney, (2012), "Does What You Export Matter? In Search of Empirical Guidelines for Industrial Policies". Washington: World Bank.

Loungani, P. and S. Mishra, (2014), “Not Your Father's Service Sector”, Finance and Development, June 2014, Vol. 51, No. 2.

MacMillan, M. and D. Rodrik (2011), “Globalization, Structural Change and Productivity Growth”, NBER Working Paper 17143, Cambridge, MA.

Martin, W. and D. Mitra, (2001), "Productivity Growth and Convergence in Agriculture and Manufacturing", Economic Development and Cultural Change.

Matisse, H., (2005), “The Economic Analysis of Product Diversity”, Maison des Sciences Économiques.

Melitz, M. (2003), "The Impact of Trade on Intra-Industry Reallocations and Aggregate Industry Productivity," Econometrica, 71(6), 1695-1725.

Mishra, S., (2015), "International Trade in Services and the Comparative Advantage of Nations: New Data and Stylized Facts”. Forthcoming IMF Working Paper.

Mishra, S., S. Lundstrom, and R. Anand, (2011), "Service Export Sophistication and Economic Growth,” World Bank Working Paper 5606.

Narain, U., G. Lange and E. Naikal, (2012), "Review of the Use of Wealth Accounts and Adjusted Net Saving in the World Bank", World Bank. 
Ocampo, J., C. Rada and L. Taylor, (2009), "Growth Policy in Developing Countries: A Structuralist Approach.” New York, New York; Columbia University Press.

Papageorgiou, C. and N. Spatafora, (2012), "Economic Diversification in LICs: Stylized Facts and Macroeconomic Implications.” IMF Staff Discussion Note. SDN/12/13.

Pritchett, L., (1997), “Divergence, Big Time”, Journal of Economic Perspectives, 11(3):317.

Rodrik, D., (2015), "Premature Deindustrialization" Institute for Advanced Studies, Princeton University Paper No. 107. January 2015.

Ross, M., (2012), "The Oil Curse. How Petroleum Wealth Shapes the Development of Nations.” Princeton, New Jersey; Princeton University Press.

Sachs, J. and A. Warner, (1995), "Natural Resource Abundance and Economic Growth". NBER Working Paper 5398.

Simoes, A., C. Hidalgo, (2011), “The Economic Complexity Observatory: An Analytical Tool for Understanding the Dynamics of Economic Development", Workshops at the Twenty-Fifth AAAI Conference on Artificial Intelligence.

Timmer, C. and S. Akkus, (2008), "The Structural Transformation as a Pathway Out of Poverty: Analytics, Empirics and Politics", Center for Global Development, Working Paper No. 150.

United Nations Commodity Trade Statistics Database.

Warner, A., (2012), "Inclusive Growth in Natural Resource Intensive Economies.” Paper prepared for The Inclusive Growth Diagnostic Analysis Conference, Nairobi, Kenya, September 28-29, 2011.

World Bank, (2014 and 2015), World Development Indicators (WDI). 
ANNEX 1: List OF NON-RENEWABLE RESOURCE ECONOMIES (NREs)

\begin{tabular}{|c|c|c|c|c|c|c|c|c|c|}
\hline & & & & & & \multicolumn{2}{|c|}{$\begin{array}{c}\text { Nominal GDP per } \\
\text { capita }\end{array}$} & \multicolumn{2}{|c|}{$\begin{array}{c}\text { Gross domestic } \\
\text { product, } \\
\text { constant prices } \\
\text { (Annual growth) }\end{array}$} \\
\hline Country & Region & $\begin{array}{l}\text { Income } \\
\text { group }\end{array}$ & $\begin{array}{l}201 \\
2 \\
\text { CPIA } \\
\text { scor } \\
\text { e }\end{array}$ & $\begin{array}{l}\text { Natural Resource } \\
\text { Exports (in \% of } \\
\text { Total Exports, } \\
\text { average, 2006- } \\
\text { 2012) }\end{array}$ & $\begin{array}{c}\text { Natural Resource } \\
\text { Fiscal Revenue (In } \\
\% \text { of Total } \\
\text { Revenue, average, } \\
2006-10)\end{array}$ & 2000-07 & 2010-12 & $2000-0$ & $10-12$ \\
\hline Congo, Dem. Rep & AFR & Low & 2.7 & 94 & 30 & 169 & 213 & 5 & 7 \\
\hline Liberia & AFR & Low & 3.1 & 30 & 16 & 320 & 392 & 6 & 7 \\
\hline Niger & AFR & Low & 3.5 & 30 & 30 & 371 & 397 & 4 & 8 \\
\hline Guinea & AFR & Low & 3.0 & 93 & 23 & 460 & 493 & 2 & 3 \\
\hline Mali & AFR & Low & 3.4 & 75 & 13 & 605 & 639 & 5 & 2 \\
\hline Chad & AFR & Low & 2.5 & 89 & 67 & 787 & 950 & 0 & 6 \\
\hline Mauritania & AFR & Low & 3.2 & 24 & 22 & 985 & 1,144 & 1 & 5 \\
\hline Côte d'Ivoire & AFR & Lower middle & 3.1 & 30 & 30 & 1,092 & 1,053 & 3 & 3 \\
\hline Cameroon & AFR & Lower middle & 3.2 & 47 & 27 & 1,169 & 1,160 & 3 & 4 \\
\hline Lao PDR & EAP & Lower middle & 3.4 & 57 & 19 & 897 & 1,290 & 8 & 8 \\
\hline Yemen, Rep. & MNA & Lower middle & 3.0 & 82 & 68 & 1,116 & 1,331 & 4 & -1 \\
\hline Vietnam & EAP & Lower middle & 3.8 & 14 & 22 & 1,058 & 1,358 & 6 & 6 \\
\hline Zambia & AFR & Lower middle & 3.5 & 72 & 4 & 1,075 & 1,370 & 6 & 7 \\
\hline Nigeria & AFR & Lower middle & 3.5 & 97 & 76 & 1,256 & 1,539 & 7 & 7 \\
\hline Uzbekistan & ECA & Lower middle & 3.4 & 50 & 50 & 1,117 & 1,554 & 9 & 8 \\
\hline Sudan & AFR & Lower middle & 2.3 & 97 & 55 & 1,398 & 1,823 & 4 & -1 \\
\hline Papua New Guinea & EAP & Lower middle & 3.3 & 77 & 21 & 1,285 & 1,915 & 6 & 9 \\
\hline Bolivia & LAC & Lower middle & 3.6 & 74 & 32 & 1,691 & 2,233 & 5 & 5 \\
\hline Syrian Arab Republi & & Lower middle & & 36 & 25 & 2,556 & 2,803 & 5 & 3 \\
\hline Mongolia & EAP & Lower middle & 3.4 & 81 & 29 & 1,898 & 3,006 & 4 & 12 \\
\hline Guyana & LAC & Lower middle & 3.3 & 42 & 27 & 2,571 & 3,287 & 3 & 4 \\
\hline Congo, Rep. & AFR & Lower middle & 3.0 & 90 & 82 & 2,913 & 3,363 & 7 & 5 \\
\hline Indonesia & EAP & Lower middle & 4.0 & 10 & 23 & 2,256 & 3,363 & 5 & 6 \\
\hline Timor-Leste & EAP & Lower middle & 3.0 & 99 & 50 & 2,865 & 3,603 & 14 & 10 \\
\hline Ecuador & LAC & Upper middle & 3.0 & 55 & 24 & 4,101 & 4,829 & 4 & 5 \\
\hline Turkmenistan & ECA & Upper middle & 2.6 & 91 & 54 & 3,930 & 5,050 & 10 & 12 \\
\hline Angola & AFR & Upper middle & 2.7 & 95 & 78 & 4,376 & 5,169 & 8 & 5 \\
\hline Algeria & MNA & Upper middle & 3.4 & 98 & 73 & 4,466 & 5,263 & 2 & 3 \\
\hline Iraq & MNA & Lower middle & 2.4 & 99 & 84 & 3,951 & 5,371 & 6 & 8 \\
\hline Iran, Islamic Rep. & & Upper middle & & 79 & 66 & 4,892 & 6,483 & 2 & 2 \\
\hline Azerbaijan & $\mathrm{ECA}$ & Upper middle & 3.7 & 94 & 64 & 5,130 & 6,815 & 10 & 2 \\
\hline Suriname & & Upper middle & & 11 & 29 & 7,114 & 8,301 & 4 & 4 \\
\hline Botswana & AFR & Upper middle & 4.1 & 66 & 63 & 6,997 & 9,026 & -1 & 5 \\
\hline Mexico & LAC & Upper middle & 4.5 & 15 & 36 & 9,014 & 9,880 & -2 & 4 \\
\hline Libya & & Upper middle & & 97 & 89 & 12,128 & 10,007 & 1 & 16 \\
\hline Kazakhstan & ECA & Upper middle & 3.8 & 60 & 40 & 7,997 & 10,733 & 2 & 7 \\
\hline Gabon & AFR & Upper middle & 3.2 & 83 & 60 & 9,504 & 11,343 & -1 & 7 \\
\hline Venezuela, RB & LAC & Upper middle & 2.5 & 93 & 58 & 11,534 & 12,532 & 1 & 3 \\
\hline Russian Federation & ECA & Upper middle & 3.9 & 50 & 29 & 10,099 & 12,752 & -1 & 4 \\
\hline Chile & LAC & Upper middle & 5.3 & 53 & 23 & 10,438 & 14,225 & 1 & 6 \\
\hline
\end{tabular}

Notes: An economy's dependence on non-renewable resources is a characteristic that changes over time. Thus there are key questions regarding the variability of the sample over time and how frequently countries move in and out of the list. Consistent with other studies, we define NREs based on the share of exports and revenues coming from non-renewables, with a threshold of $20 \%$ (see IMF, 2012). 


\section{Annex 2. Technical Notes on Trade Analysis}

There is a large body of literature that has grown around methodology to measure diversification, sophistication, and complexity in merchandise trade. This strand of literature provides detailed information about the income and diversification potential of different strategies, considering links between sectors. The key data source for the PS analysis is Comtrade's global trade records (the SITC Rev. 2 Classification at the 4-digit level, covering 784 products and 130 countries from 1980 to 2012); ${ }^{27}$ this information is complemented by country-level data on GDP per capita. The data on services trade is obtained from IMF Balance of Payments, BPM6.

Empirically, the analysis involves the construction of set of export-related indicators, showing both the historical record of a country and indicative projections into the future. Some of these including the Herfindahl index $(\mathrm{HI})$, and revealed comparative advantage $(R C A)$ are standard. ${ }^{28}$

\section{Diversification}

More specifically, the standard indicators may be defined as follows, with the indices $c$ (or $c^{\prime}$ ), $i$ (or $i$ ' or $i^{\prime \prime}$ ), and $t$ referring to countries, goods (or services), and years, respectively. Export Diversification in service exports $(H I)$ is a time- and country-specific measure of export concentration by country, and time period:

$$
H I_{c, t}=\sum_{i}\left(\frac{E_{c, i, t}}{\sum_{i^{\prime}} E_{c, i^{\prime}, t}}\right)^{2}
$$

\section{Quality}

Export quality is estimated using unit values (average traded price for each product category) are observable. Schott (2004) and Hummels and Klenow (2005) showed that these unit values increase with GDP per capita. ${ }^{29}$ Our methodology estimates quality based on unit values, but with two important adjustments. The methodology is a modified version of Hallak (2006), which sidesteps data this is meant to capture cross-country variations in production costs systematically

\footnotetext{
${ }^{27}$ Alternatively, PS analysis may be done using the much more finely disaggregated Comtrade Harmonized System database.

${ }^{28}$ Indicators of the technological content of exports are also frequently included in analyses of structural transformation as it is indicative of the sophistication of a country in a given product category. Technologically sophisticated products tend to be associated with a high PRODY.

${ }^{29}$ This sparked an interest in estimating export quality, for which unit values are at best a noisy proxy, being driven also by a series of other factors, including production cost differences. The strategies recently developed for quality estimation (including Khandelwal, 2010, Hallak and Schott, 2011, and Feenstra and Romalis, 2012) typically model demand, and in some cases also supply, using explicit microeconomic foundations. However, these methodologies do not allow calculation of a set of quality estimates with large country and time coverage, owing to their significant data requirements.
} 
related to income. With high-income countries typically being capital-abundant, labor-intensive sectors while also accounting for distance between importer and exporter. This accounts for selection bias: typically, the composition of exports to more distant destinations is tilted towards higher-priced goods, because of higher shipping costs.

\section{Trends in Comparative Advantage}

The Revealed Comparative Advantage (RCA), a concept introduced by Balassa (1965), is a measure constructed to inform whether a country's share of a product's world market, is larger or smaller than the product's share of the entire world market. Mathematically, the RCA of a nation is measured by the relative weight of a percentage of total export of a product (or service) in a nation over the percentage of world export in that product (or service). $\mathrm{K}$ is an industrial index while $\mathrm{j}$ is a country index, $\mathrm{X}$ is export, using this notation, RCA can be written as:

$$
R C A_{k j}=\frac{X_{k}^{j} / \sum_{k} X_{k}^{j}}{\sum_{j} X_{k}^{j} / \sum_{k} \sum_{j} X_{k}^{j}}
$$

On the basis of the evolution of their $R C A \mathrm{~s}$, exported products may be classified as classic, emerging, disappearing, or marginal. The classical may be understood as the traditional exports of a country, i.e., services in which the country has always had a comparative advantage. The emerging champions are services in which the country did not have a comparative advantage in the past but developed it in recent years. The time periods 'past' and 'present' can be specified by the analyst. The disappearing products are those in which the country had a comparative advantage in the past but does not have it anymore, and the marginal services are those in which the country never has had a comparative advantage.

$\begin{array}{lll}\text { Table 1. Definition of "Classical", "Marginal", "Disappearing", and "Emerging" Products } \\ \text { 2000-2006 } \\ \text { Classical } & \mathrm{RCA}>1 & 2007-2012 \\ \text { Marginal } & \mathrm{RCA}<1 & \mathrm{RCA}<1 \\ \text { Disappearing } & \mathrm{RCA}>1 & \mathrm{RCA}<1 \\ \text { Emerging } & \mathrm{RCA}<1 & \mathrm{RCA}>1\end{array}$




\section{Annex 3. Supplemental Figures and Tables ${ }^{30}$}

\section{Figure I. Non-Renewable Resource Export Growth and Size of Resource in GDP}

Panel A. Non-Renewable Resource Export Growth by Type (GDP Growth is size)

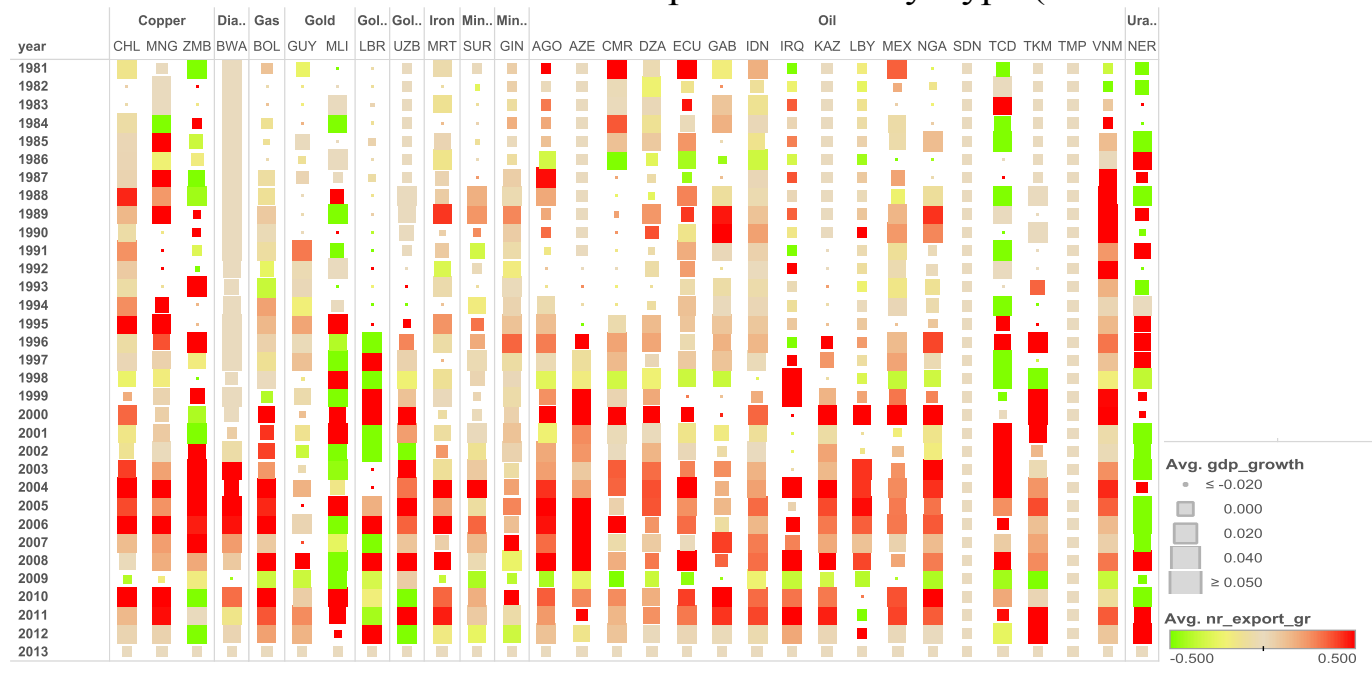

Panel B. Non-Renewable Resource Export Growth by Typ

(Total Non-Renewable Resource Revenue in GDP is size)

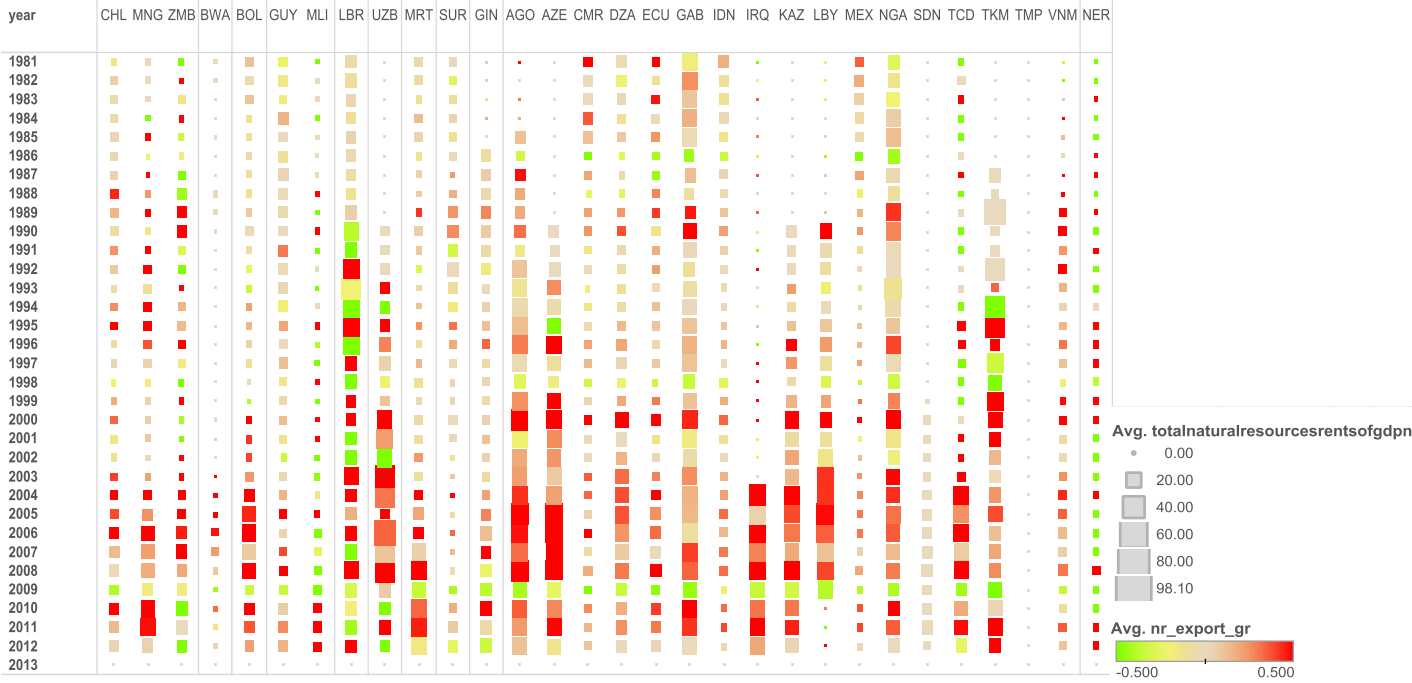

Source: Authors' calculations using WITS Database, WDI, and IFS, 2014. Classification based on IMF (2012).

Notes: Panel A: marker color shows export growth; marker size shows GDP growth. Panel B: marker color shows export growth; marker size shows resource revenue, as a share of GDP.

\footnotetext{
${ }^{30}$ Roman numerals are used for figures/tables in this annex, to differentiate from those found in the main text.
} 
Figure II. Structural Shifts and Stages of Development Panel A. Broad-Based Structural Changes in NREs

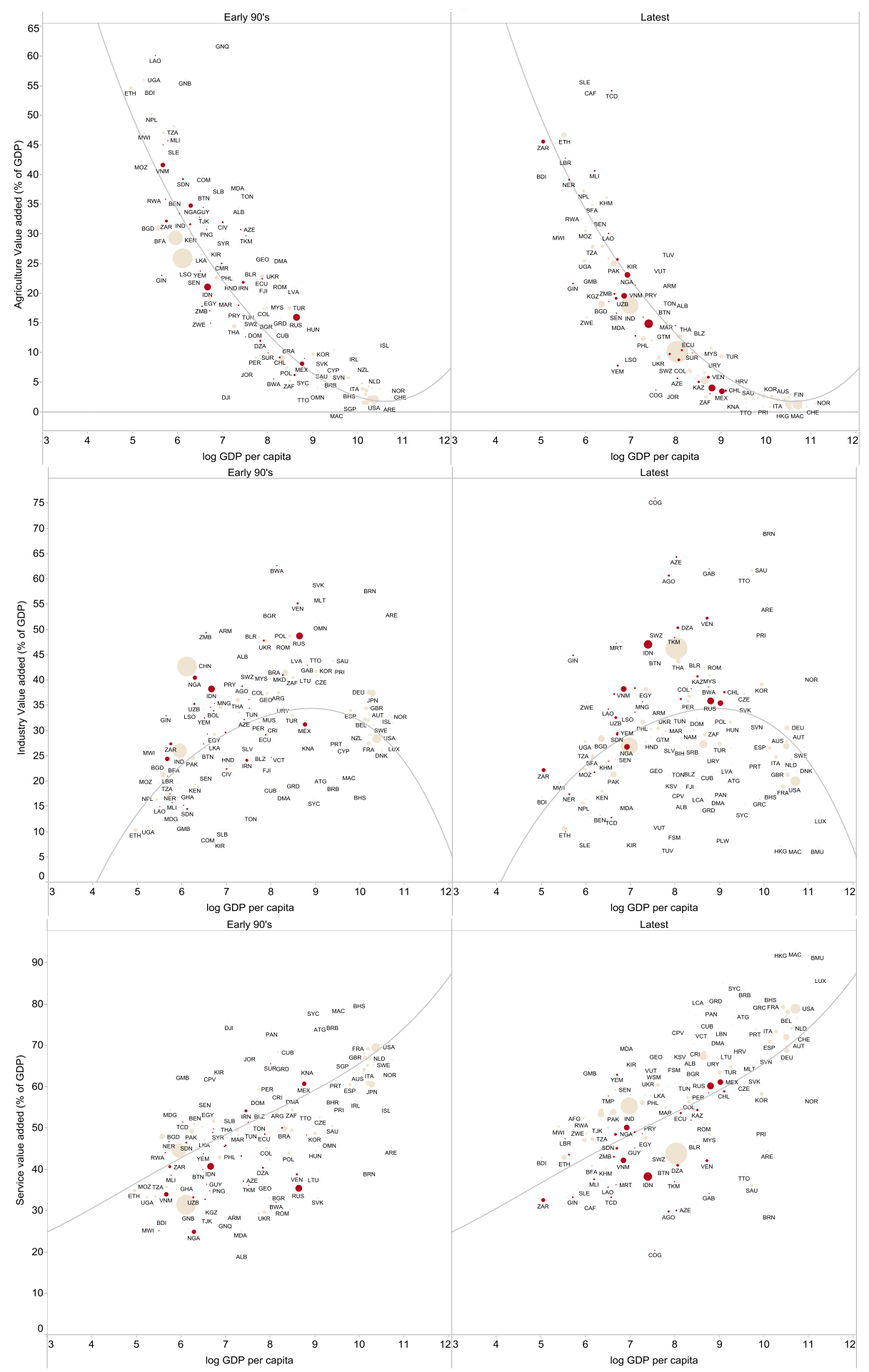

Source: World Development Indicators, World Bank, 2014. 


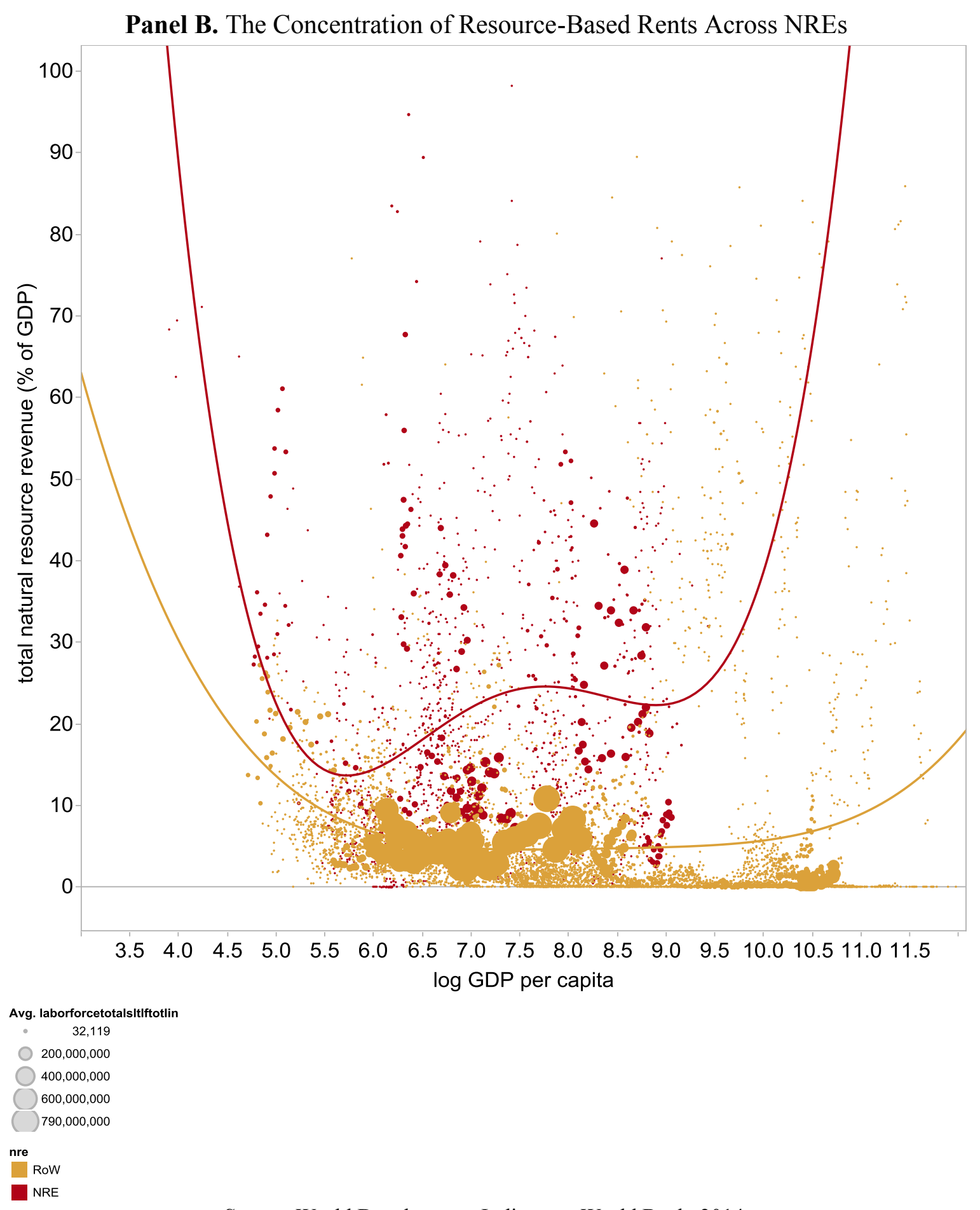

Source: World Development Indicators, World Bank, 2014. 
Panel C. Relative Low Share of Manufactruing and High Resource Rent Across NREs
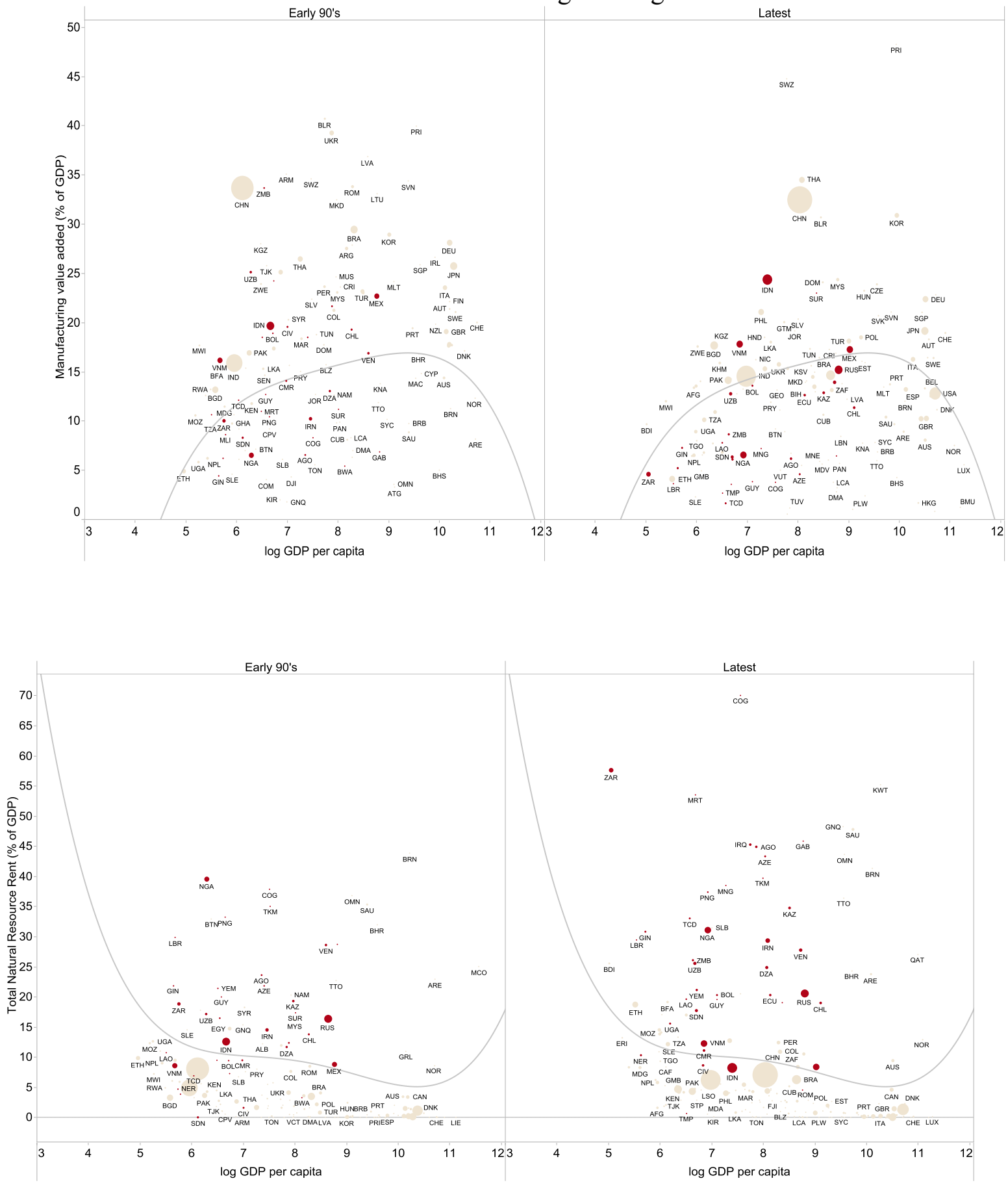

Source: World Development Indicators, World Bank, 2014. 


\section{Figure III. Scope for Productivity Enhancement in NREs}

Panel A. Aggregate Sectoral Productivity

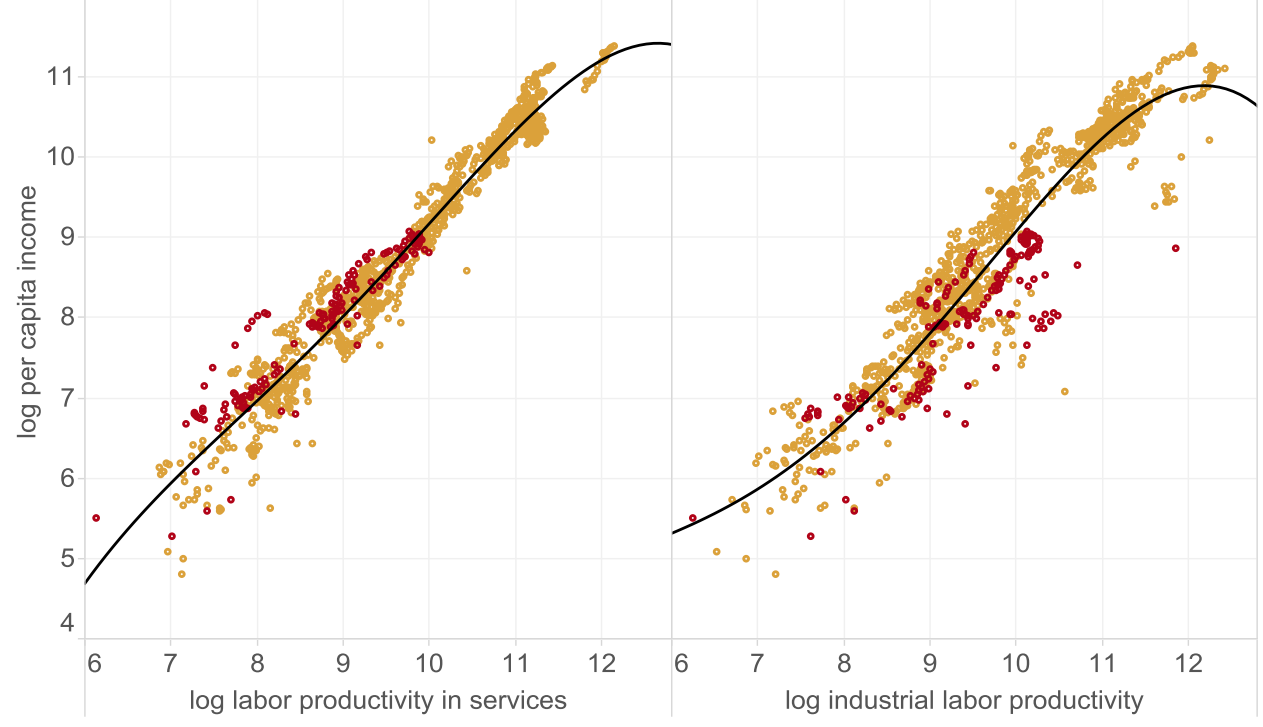

Panel B. Manufacturing and Mining Productivity

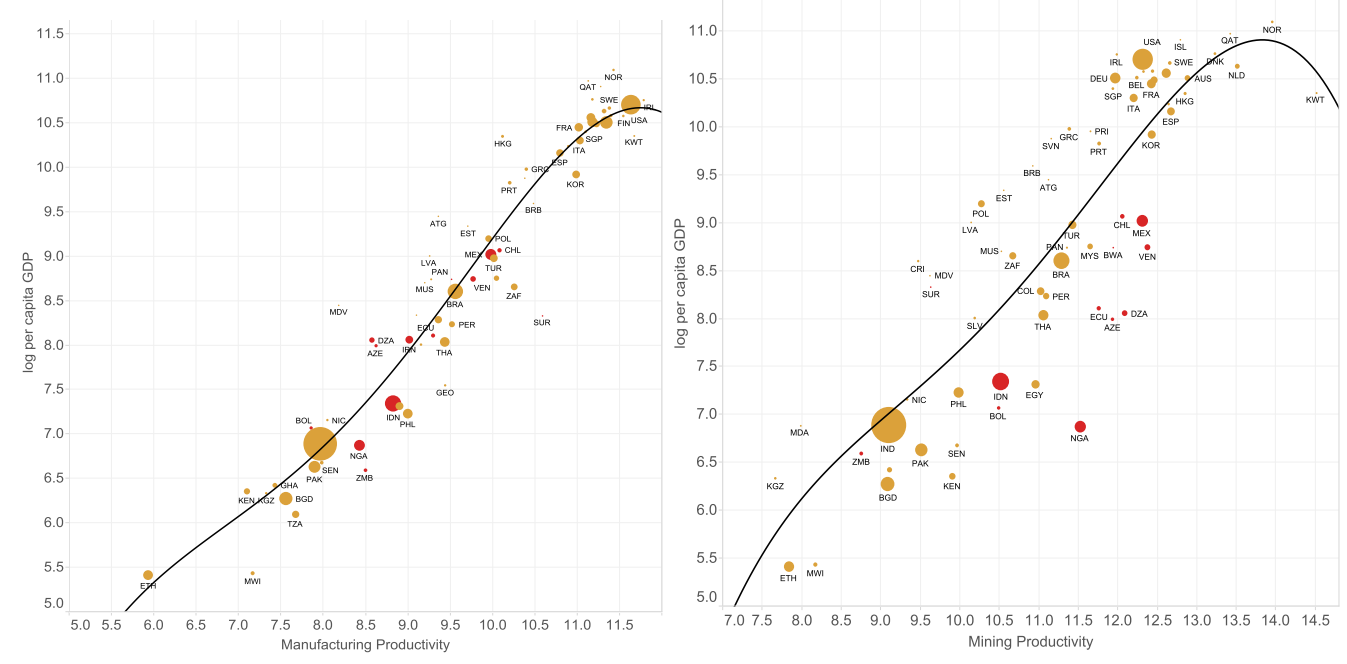

Source: Authors' calculations based on Penn World Table Version 8.0, UN National Accounts Database, International Labor Organization, GGDC, WDI, and IMF (2014). 
Panel C. Service Productivity

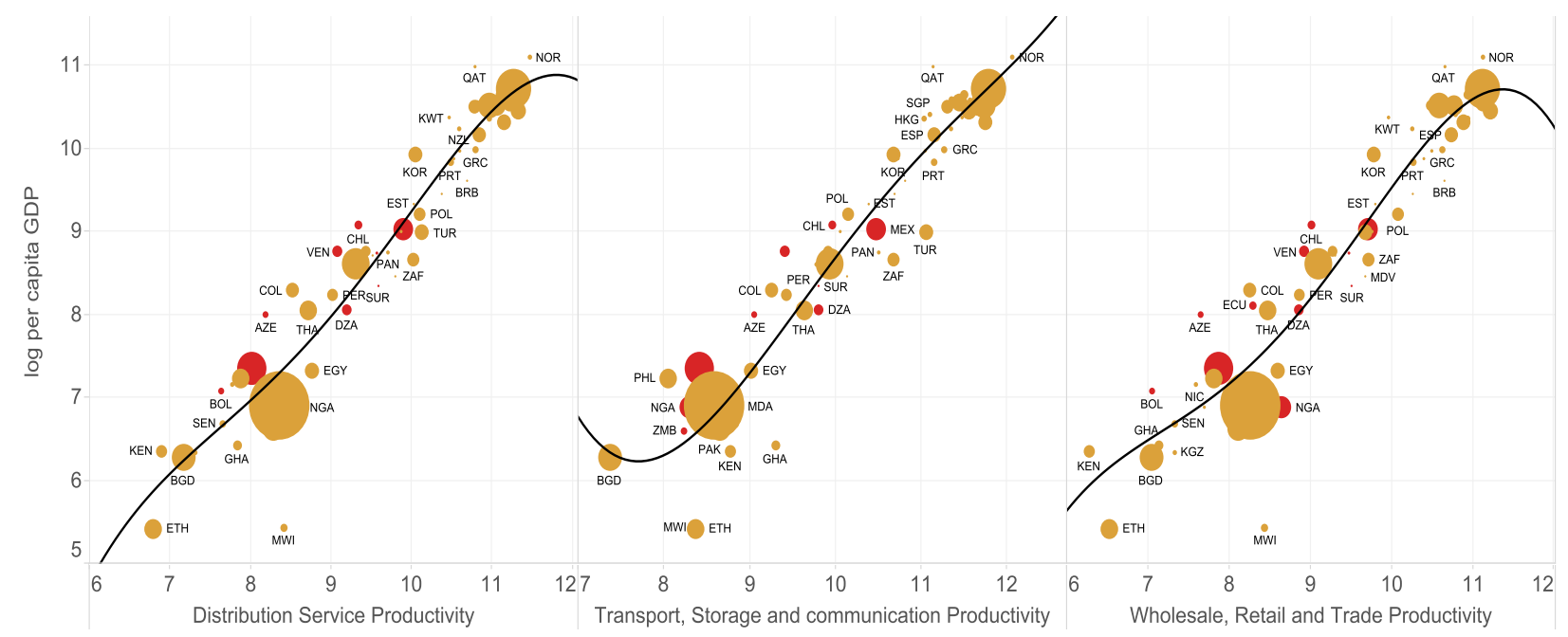

Source: Authors' calculations based on Penn World Table Version 8.0, UN National Accounts Database, International Labor Organization, GGDC, WDI, and IMF (2014). 
Figure IV. Labor and Capital Shares of GDP

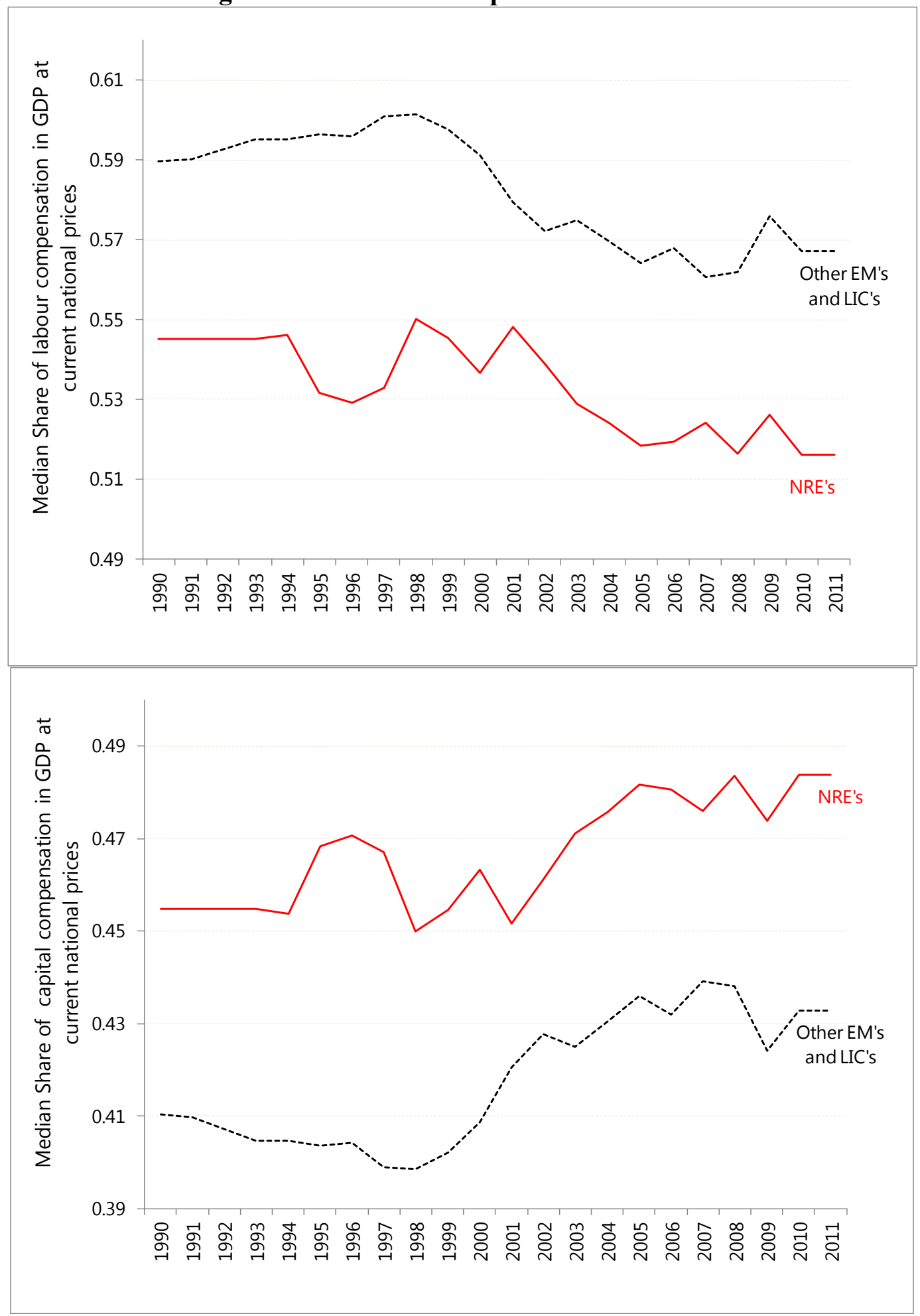

Source: Authors' calculations using IMF Productivity Dataset, 2013. 
Figure V. NREs Gains from Productivity-Enhancing Processes in Services

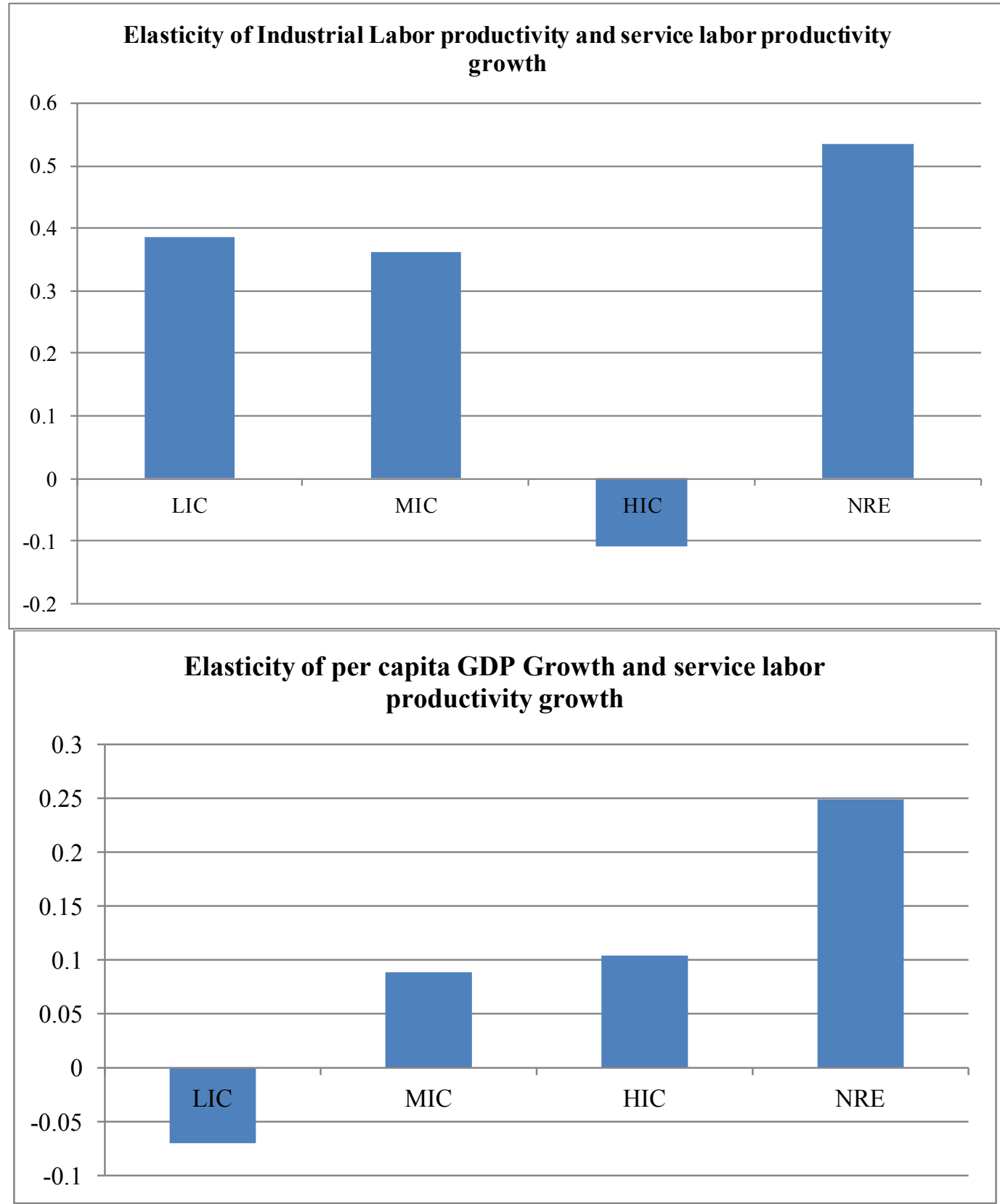

Source: Authors' calculations using panel fixed effect regression for unbalance panel data spanning 1960-2013 for 98 countries. The bar chart displays the coefficient or magnitude of elasticity. 
Figure VI. Shifts in Manufacturing Content of Export Basket in NREs

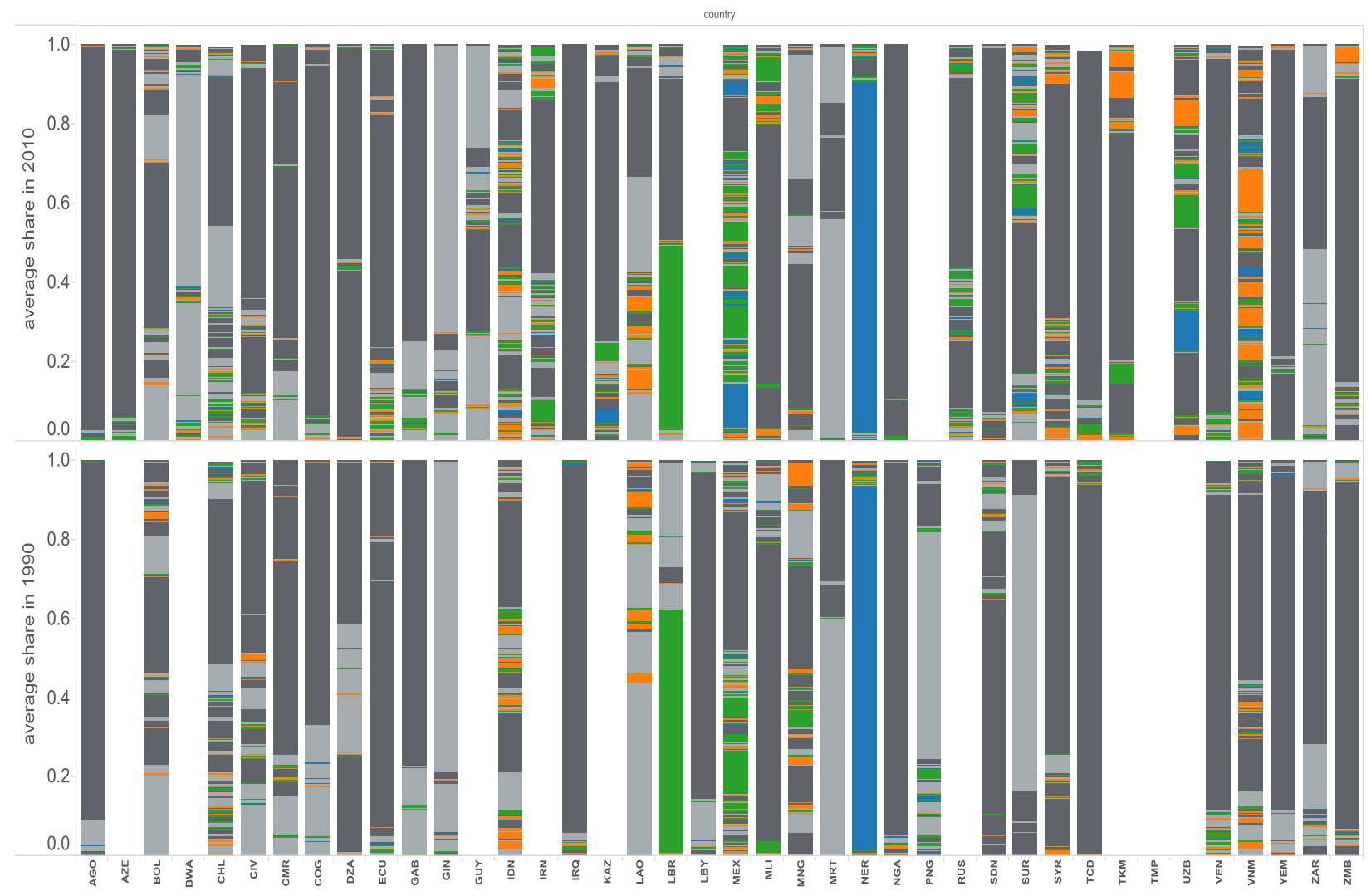

tech (group)

Hi Tech Mfg

Lo tech $\mathrm{mfg}$

Medium tech mfg

Primary

Resource Based 
Figure VII. Service Exports from NREs

Service Exports / Service Value added (\%) in NREs

NRE

year

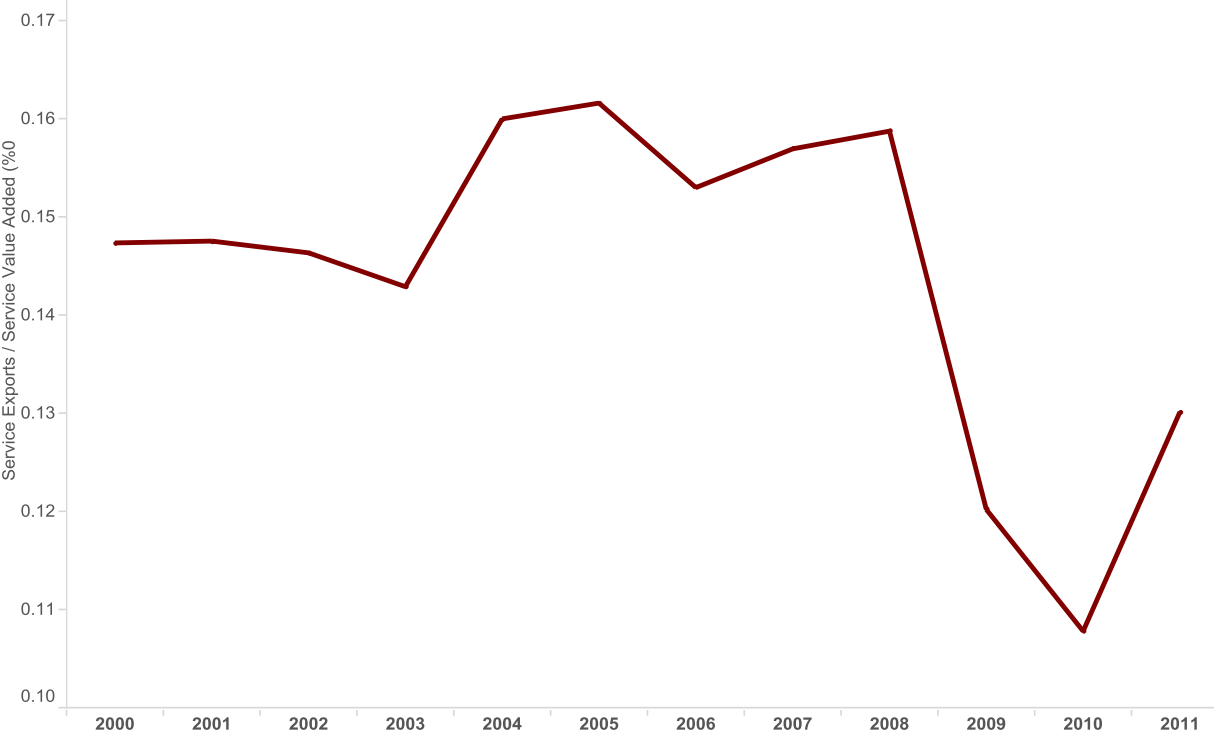

Source: Authors' calculations using BPM6 BoP, IMF 2014. 
Panel B. NREs versus Other Developing Countries

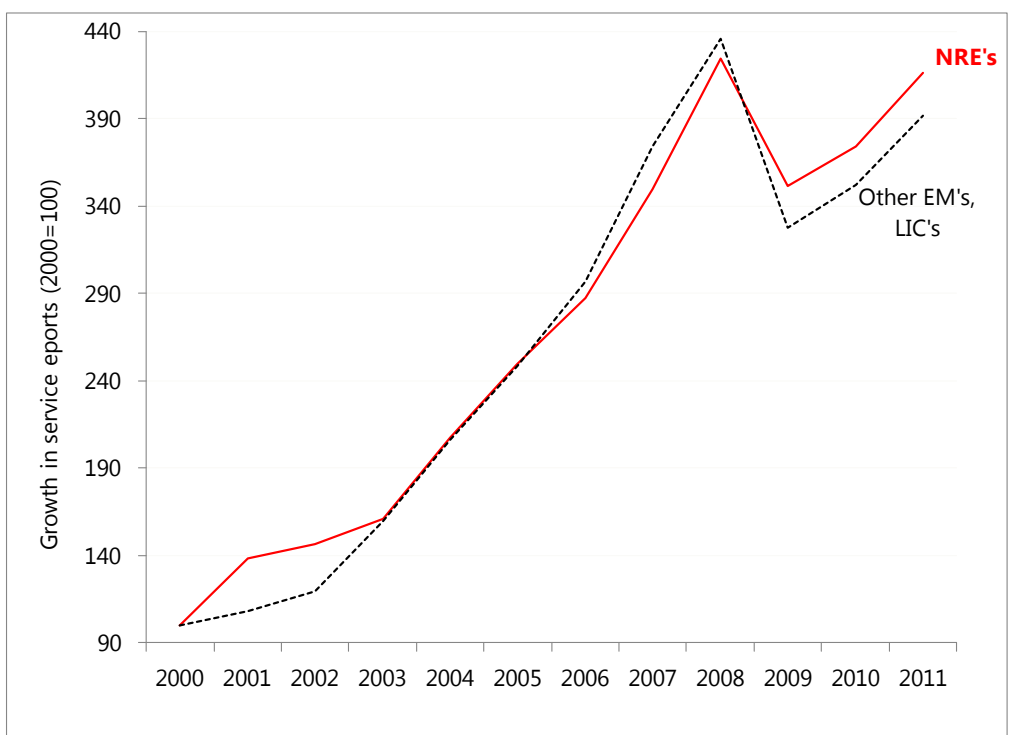

Source: Authors' calculations using BPM5 BoP, IMF 2014.

Notes: Other EMs and LICs includes high income, non-OECD countries.

Panel C. Growth in Modern Service Exports from NREs

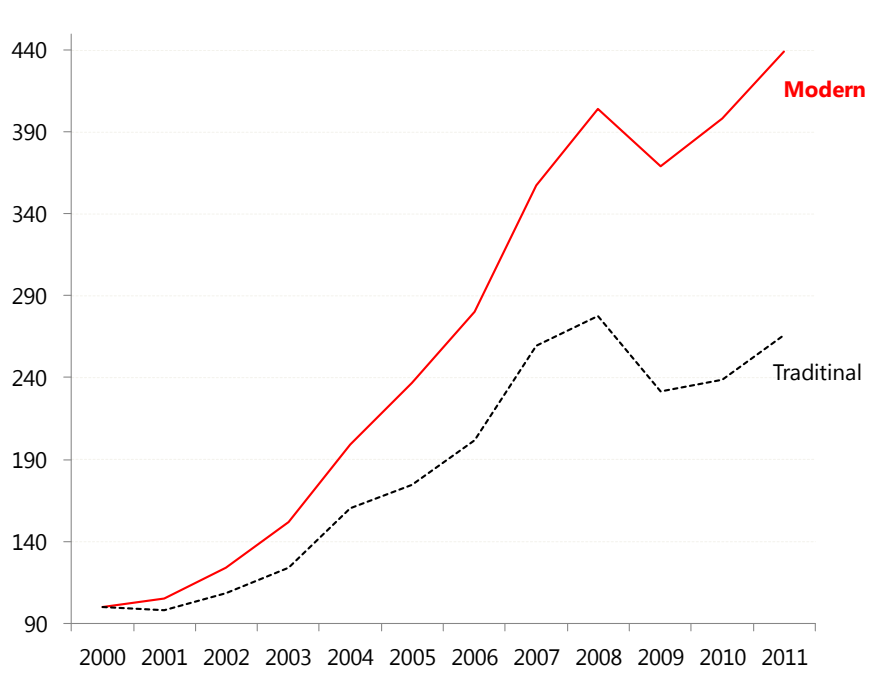

Source: Authors' calculations using BPM5 BoP, IMF 2014.

Notes: To cover the full sample of NREs, "modern" services in this chart are defined as those with above-average income earning potential, as measured by the weighted average of the income per capita of the countries that export the given service. 
Figure VIII. Benchmarking Export Diversification in NREs (2007-2012)
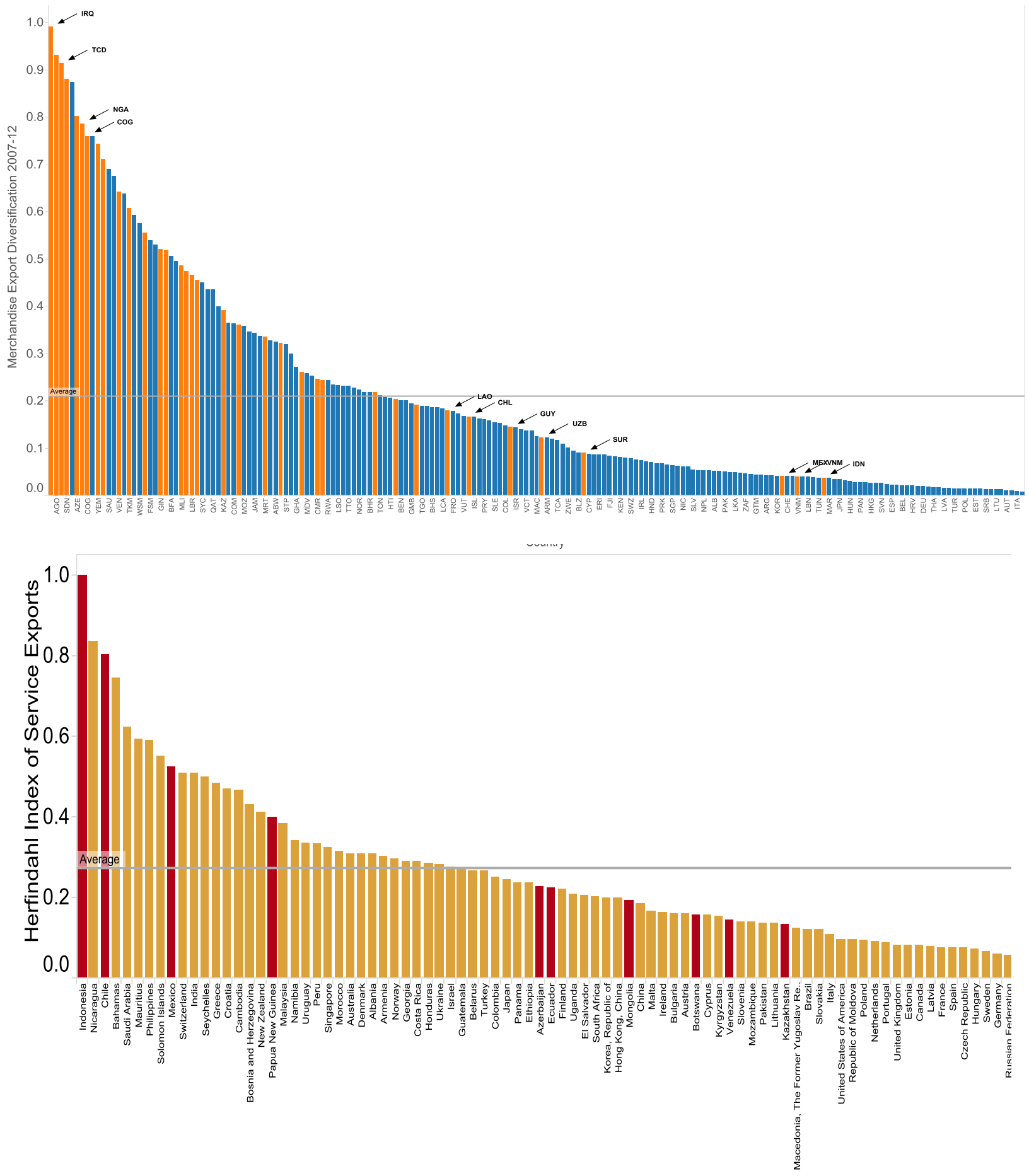
Figure IX. Quality of Exports in NREs

Panel A. Quality of Select Merchandise Exports, 2010

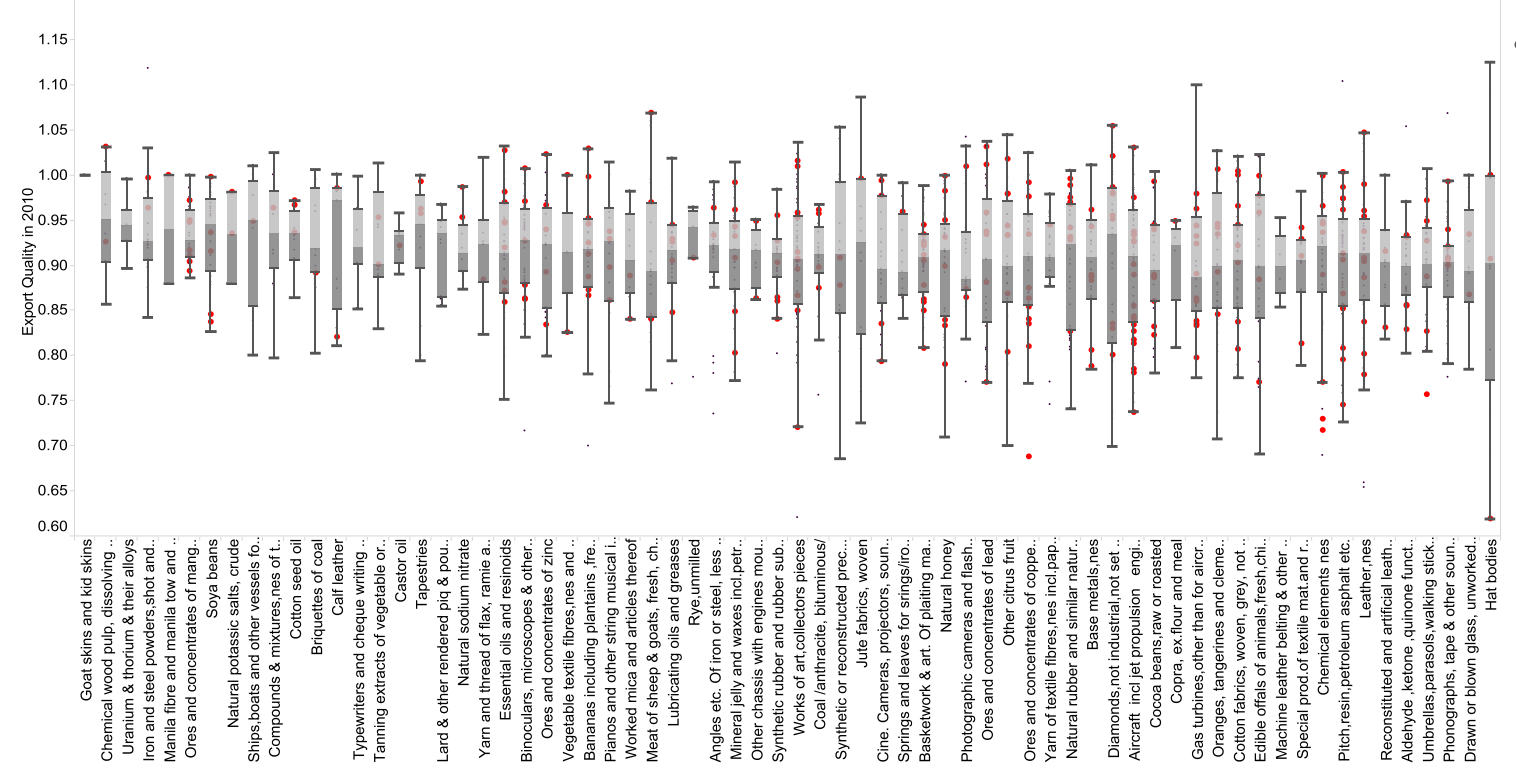

Panel B. NRE vs non-NRE Quality of Select Merchandise Exports, 2010

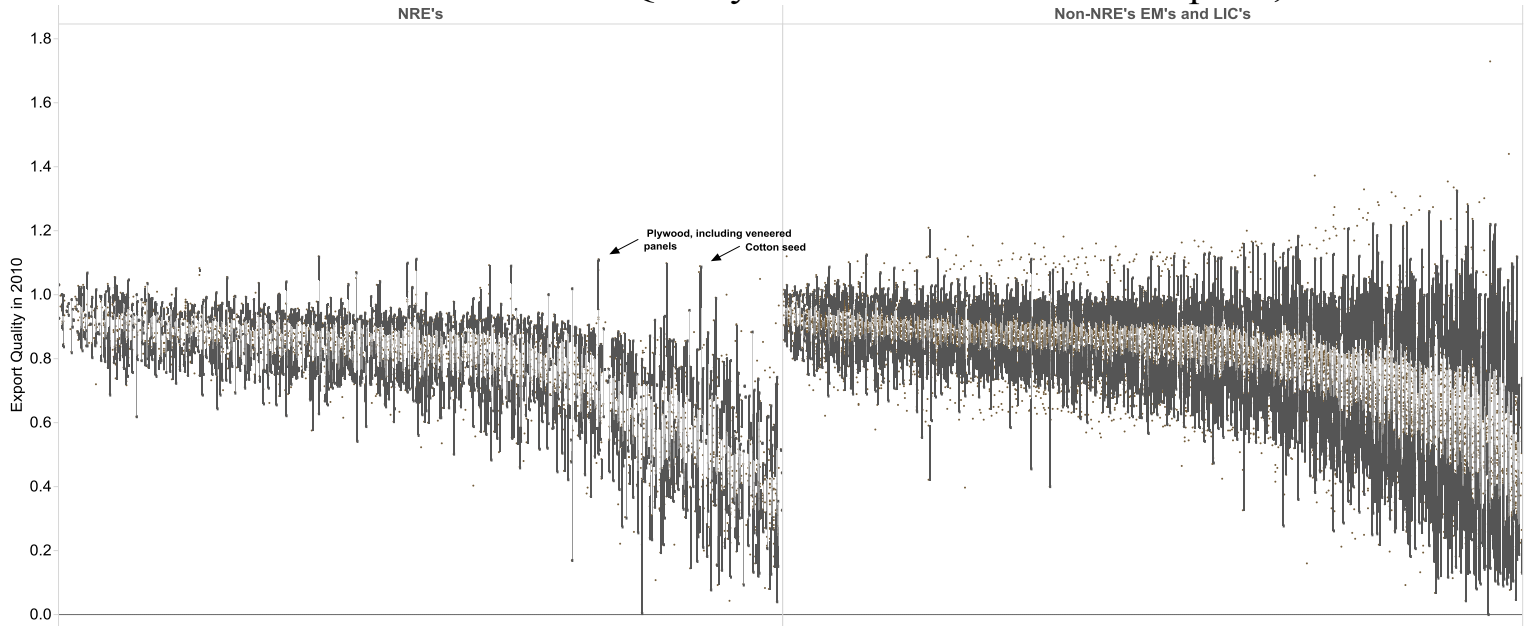

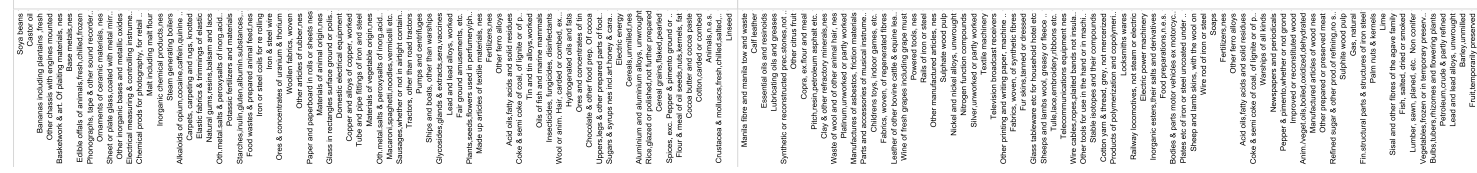


Panel C. NRE Merchandise Export Quality (Median)

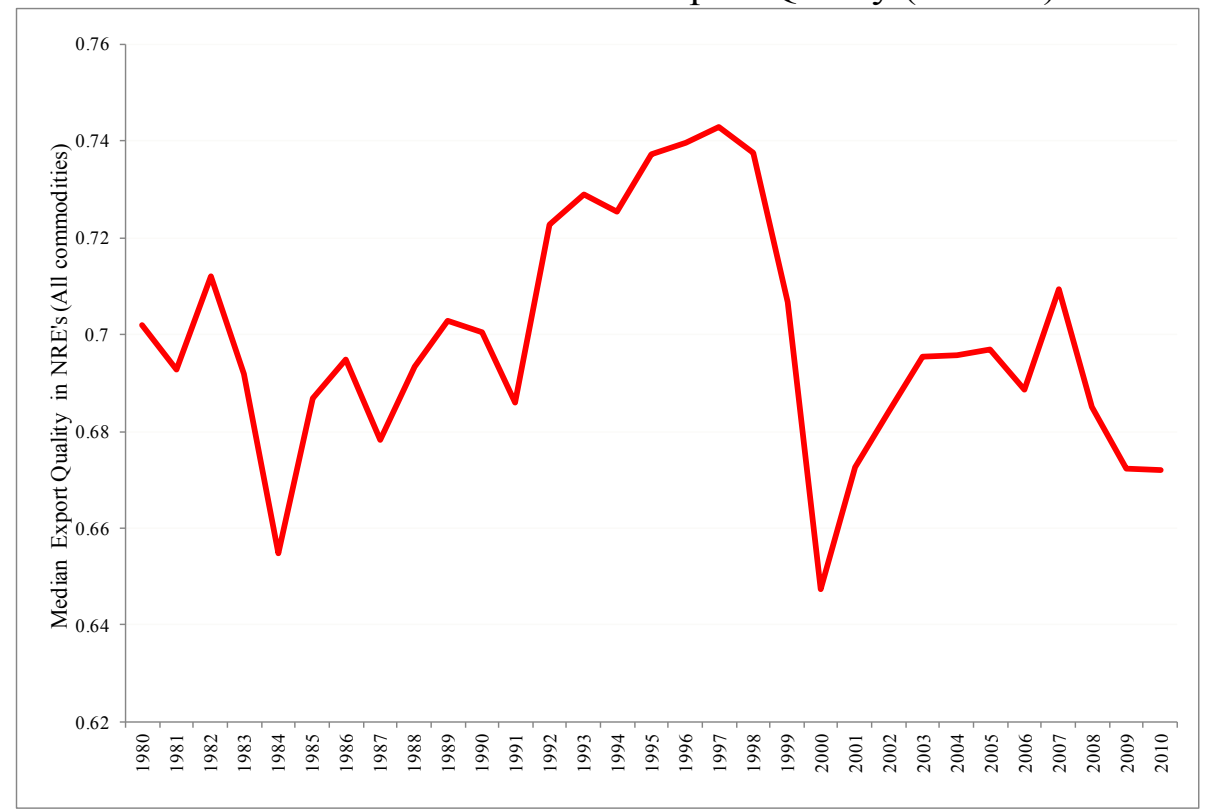


Figure X. Benchmarking Comparative Advantage of Merchandise Exports Probability of comparative advantage (Product Space Measure Density)

Panel A. Potential for Comparative Advantage in Manufacturing Exports

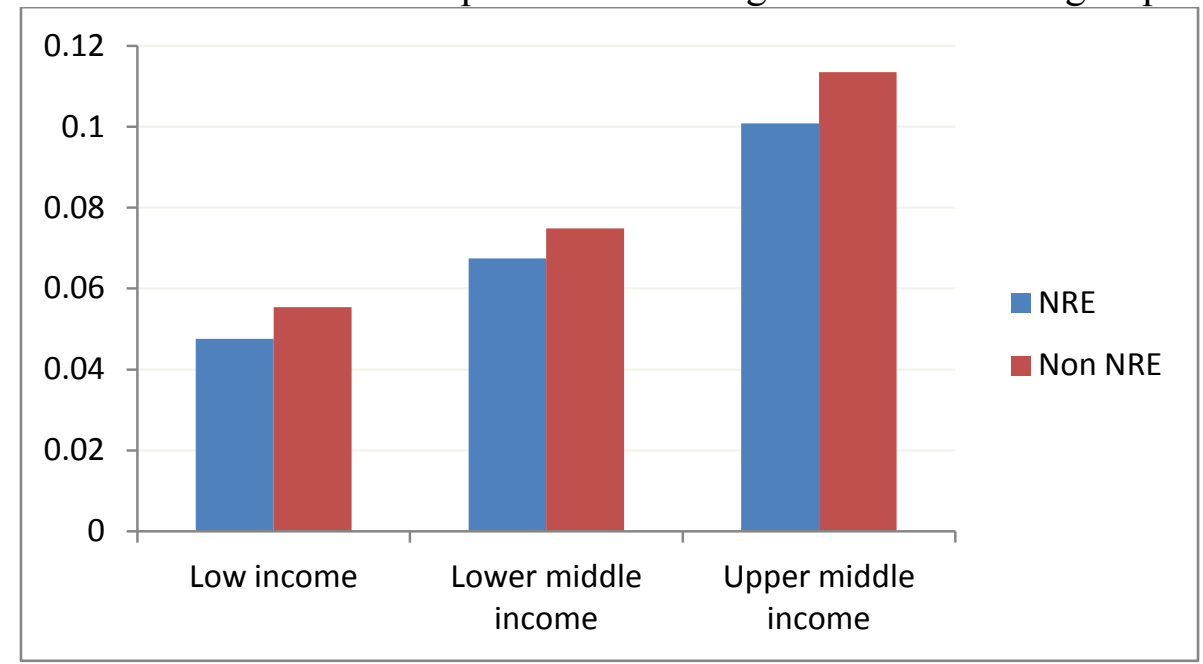

Panel B. Potential for Comparative Advantage in Primary and Resource Based Exports

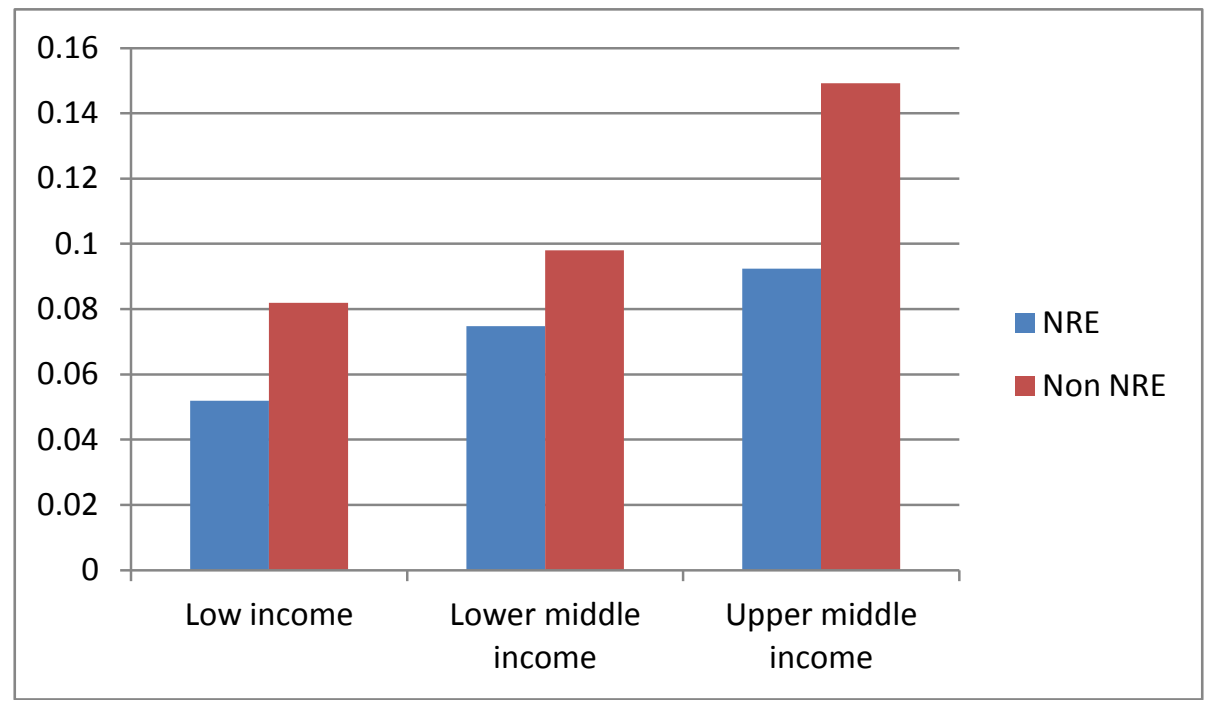


Panel C. Growing comparative advantage in NREs Guinea, Gambia, Vietnam, and Indonesia growing new comparative advantage
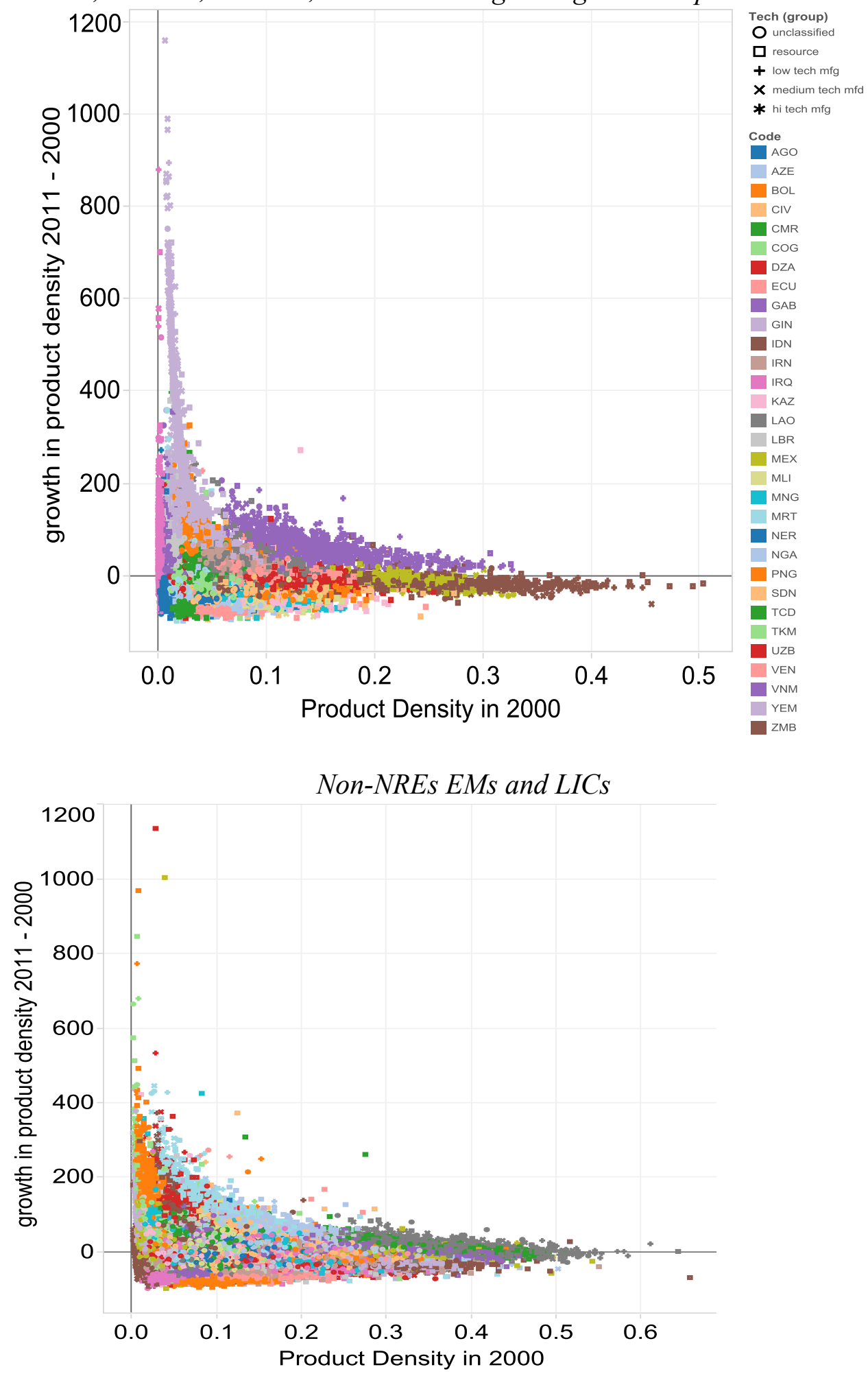

C)International Monetary Fund. Not for Redistribution 
Panel D. Comparative Advantage Over time in NREs with other Developing Countries

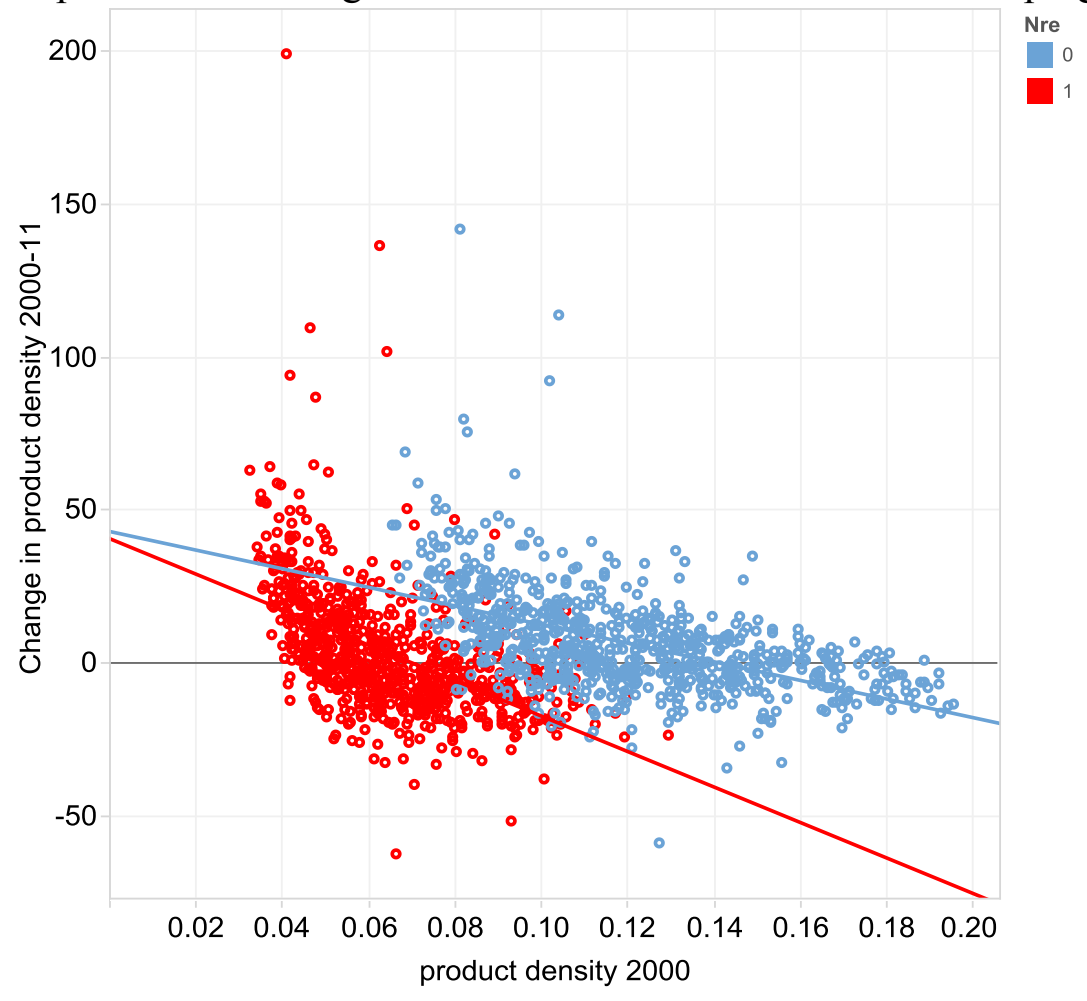

Panel E. NRE's Goods Exports

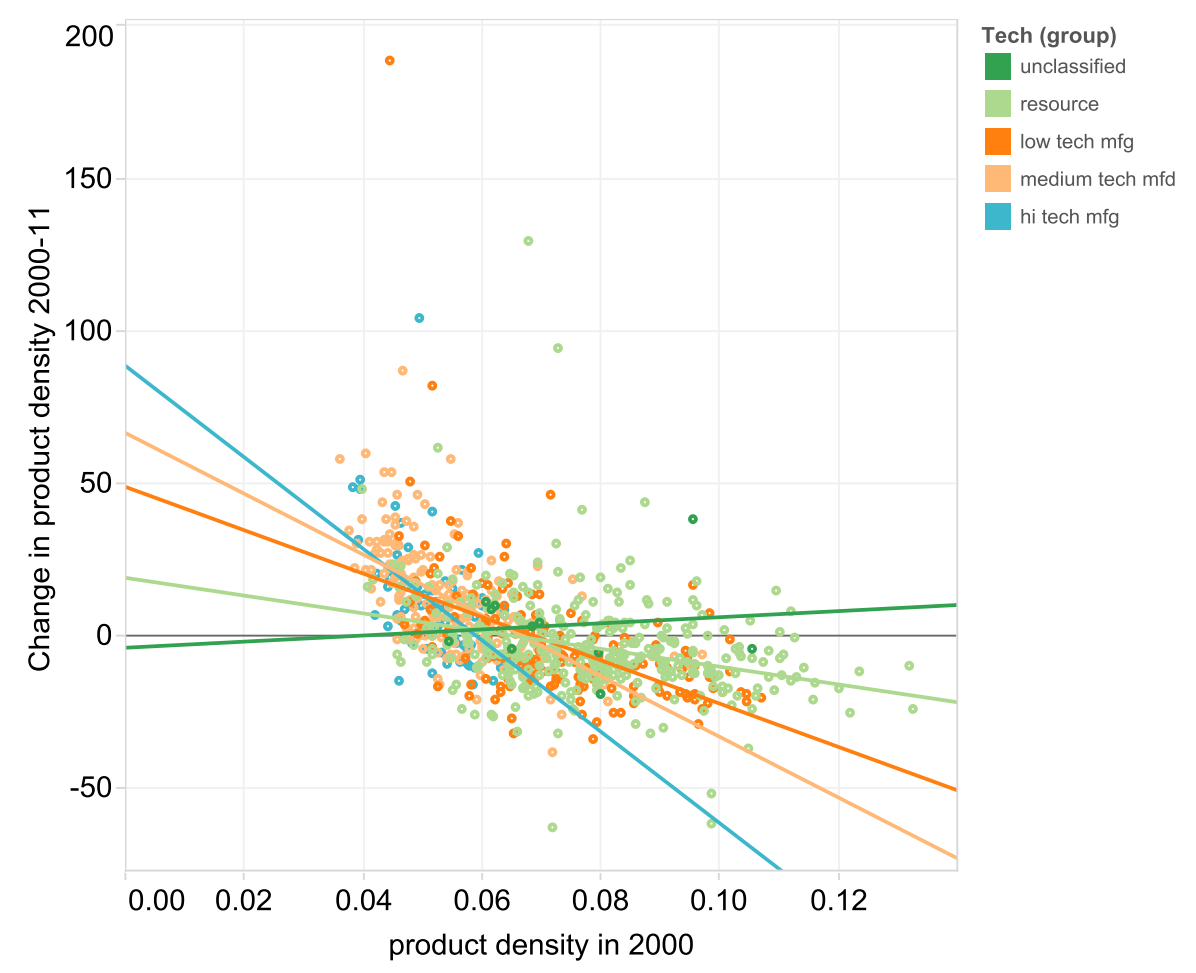

CInternational Monetary Fund. Not for Redistribution 
Figure XI. Export Composition in 2012

Panel A. Indonesia

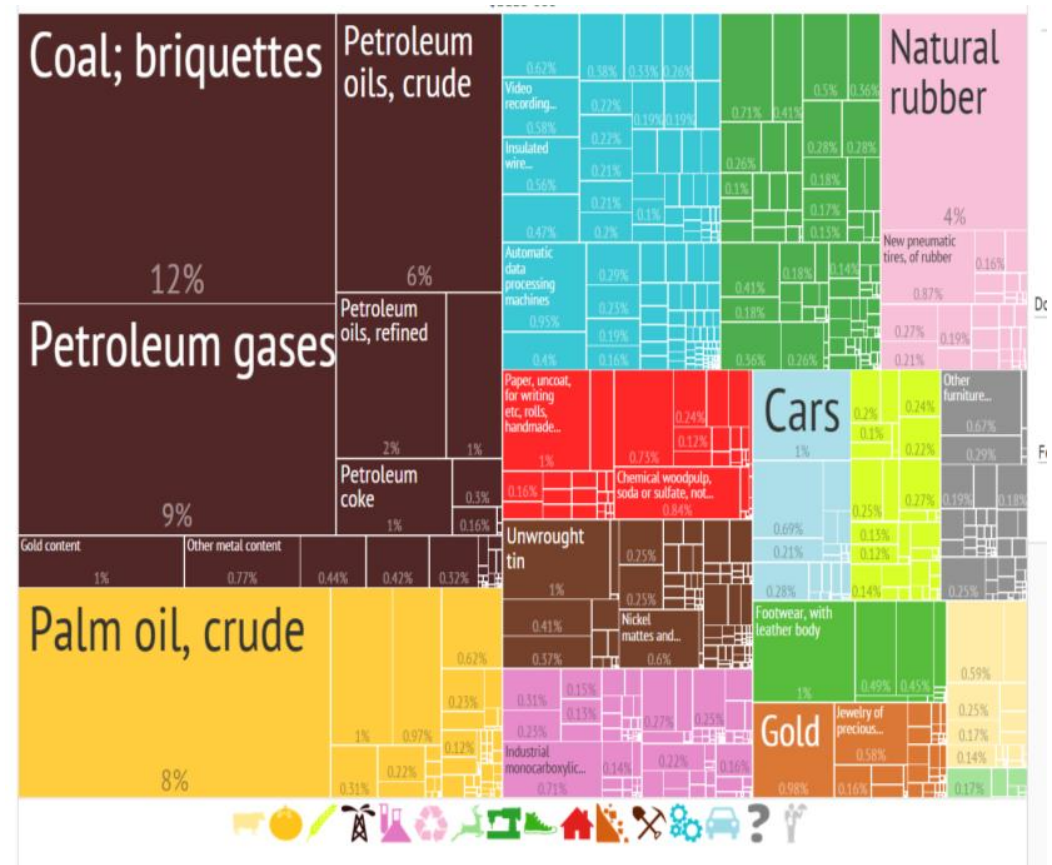

Panel B. Chile

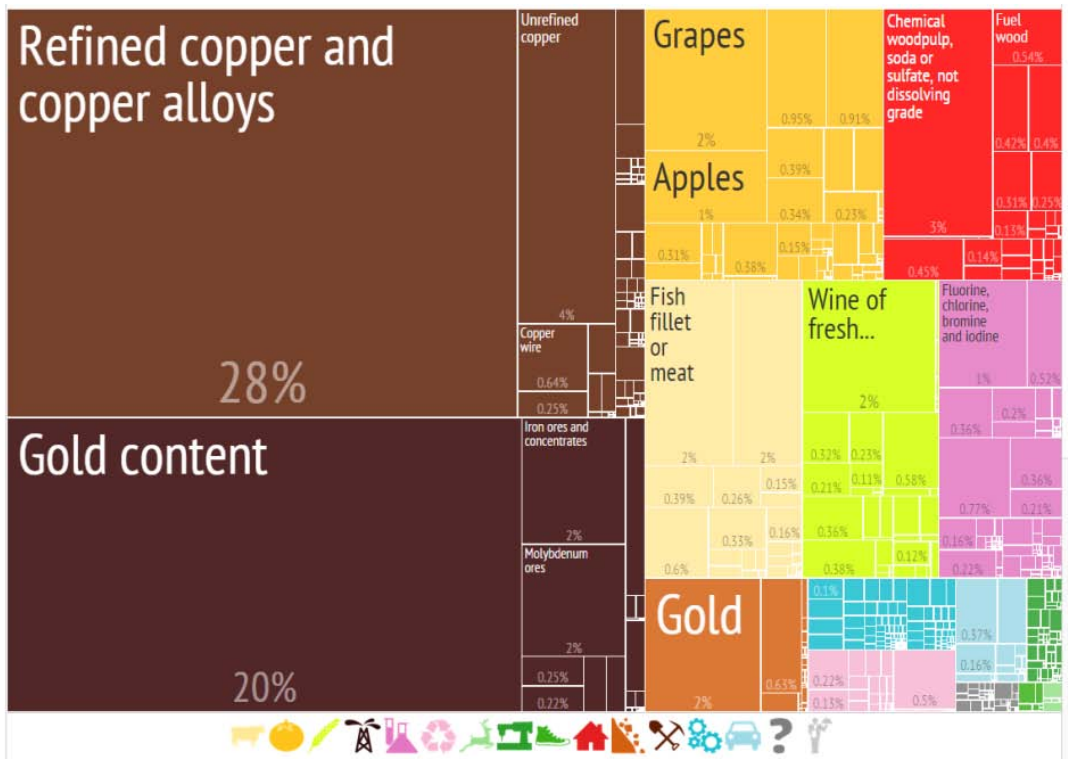

Source: Atlas of Economic Complexity, Haussmann, Hidalgo et al. 2014. 
Panel C. Syrian Arab Republic
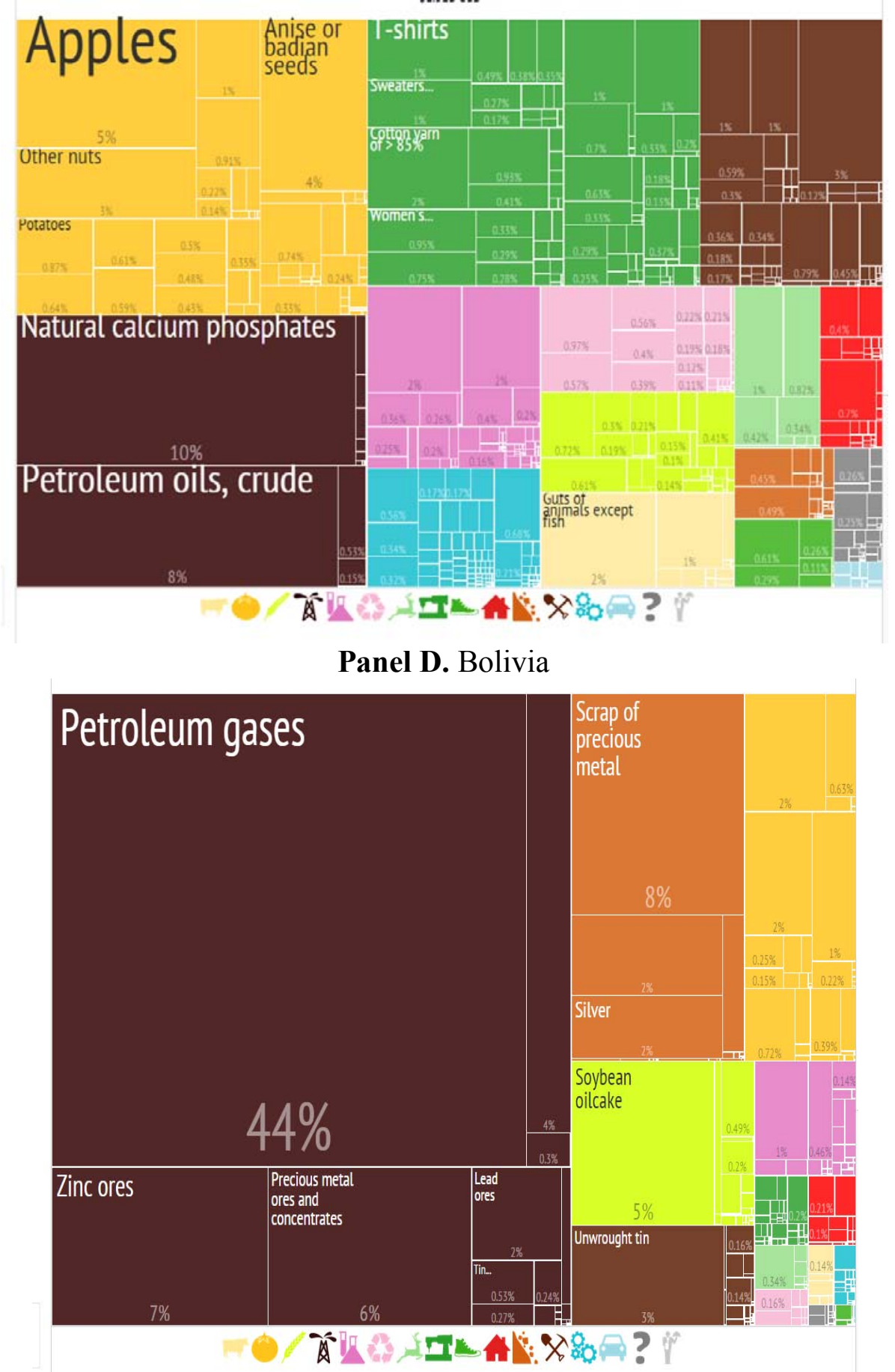

Source: Atlas of Economic Complexity, Haussmann, Hidalgo et al. 2014. 
Panel E. Iraq

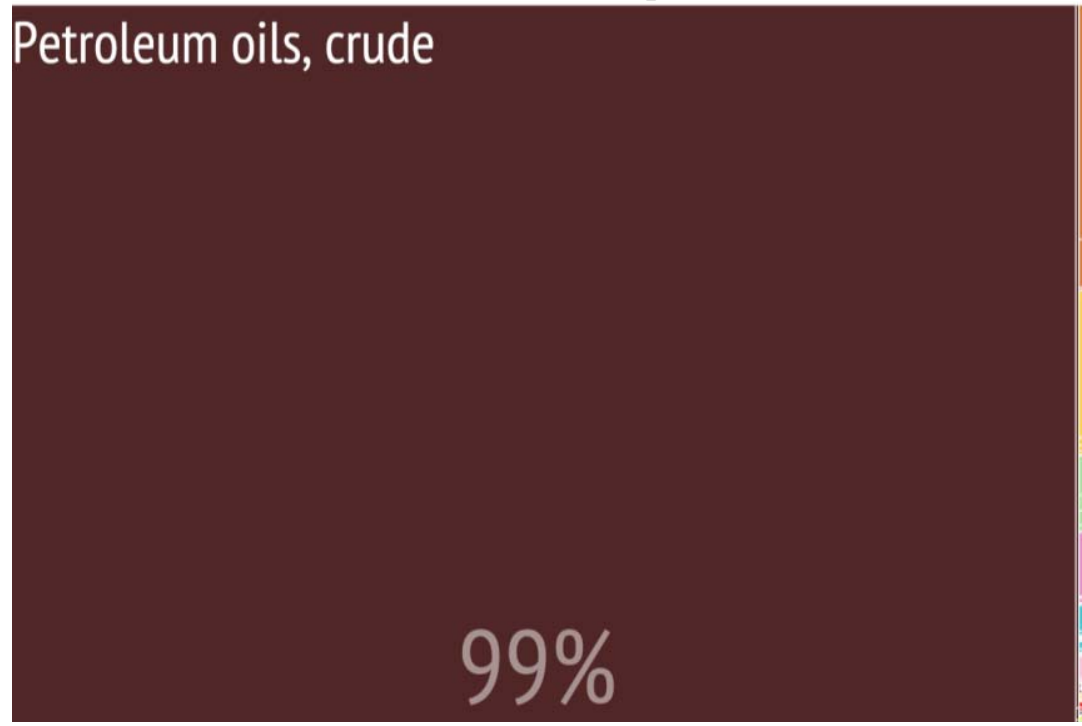

Panel F. Mali

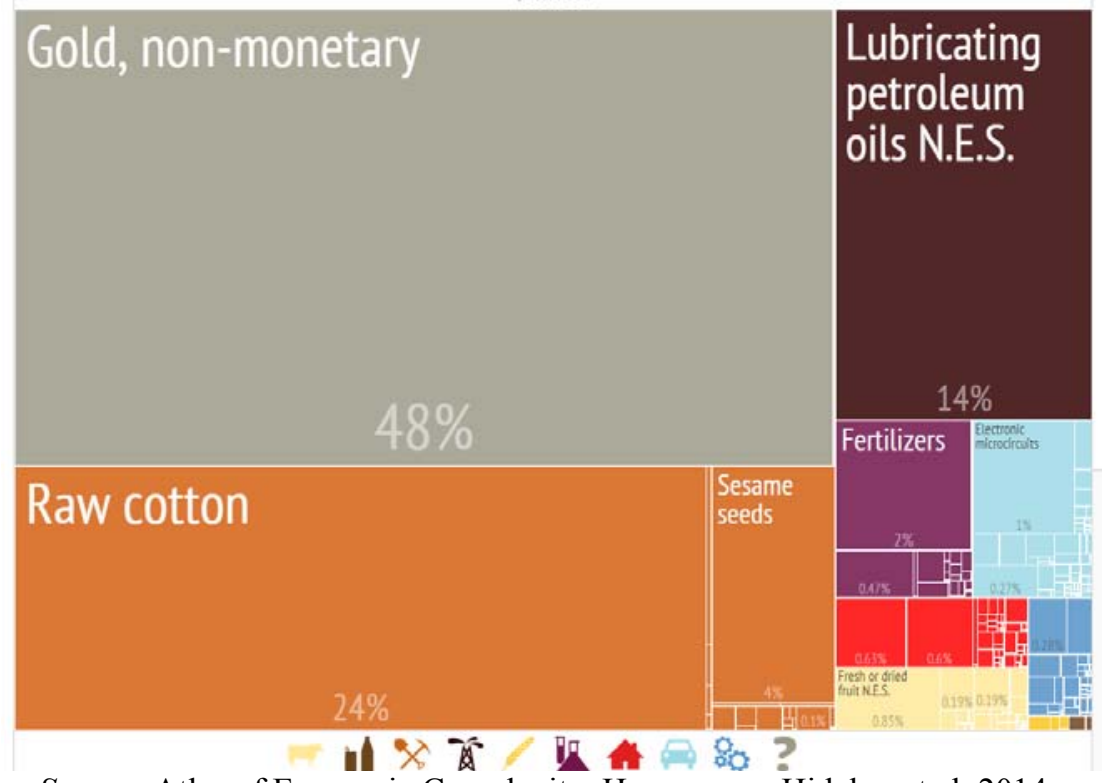

Source: Atlas of Economic Complexity, Haussmann, Hidalgo et al. 2014. 
Figure XII. NREs' Low Competitiveness in Manufacturing Exports Panel A. NRE Resource and Manufacturing Exports

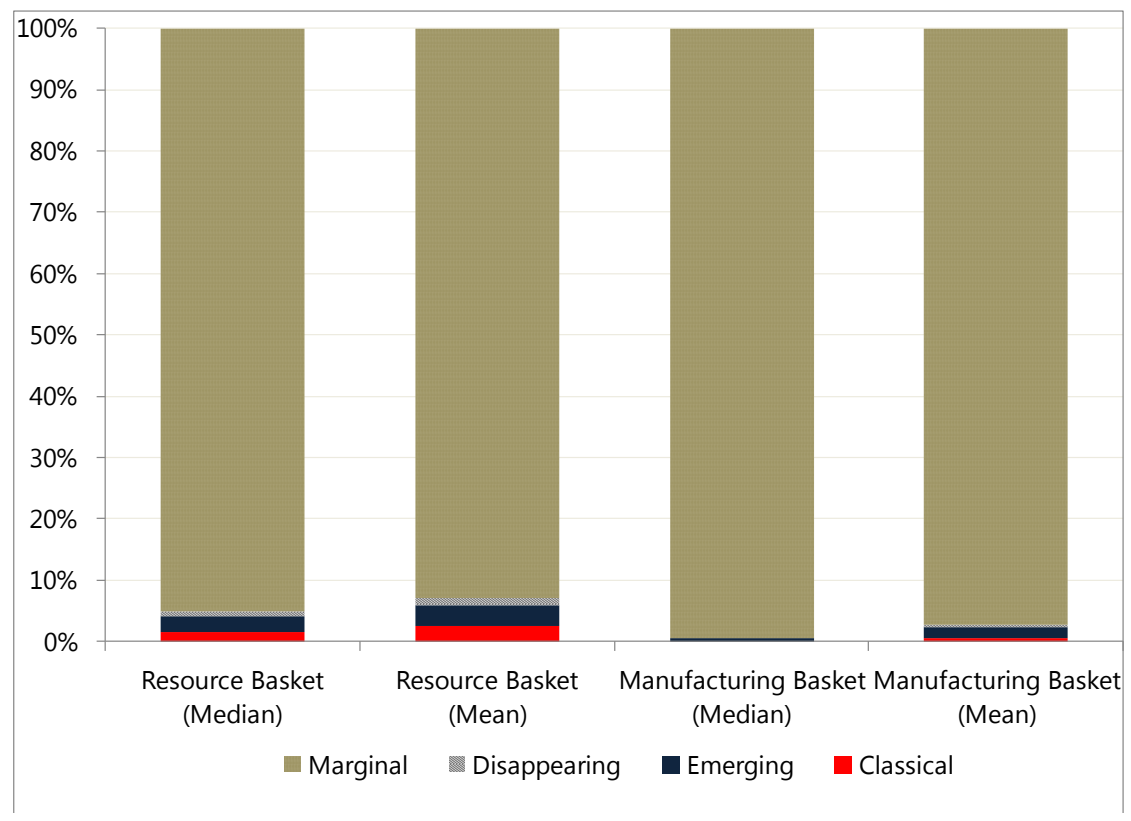

Panel B. NRE Resource Exports, by Country

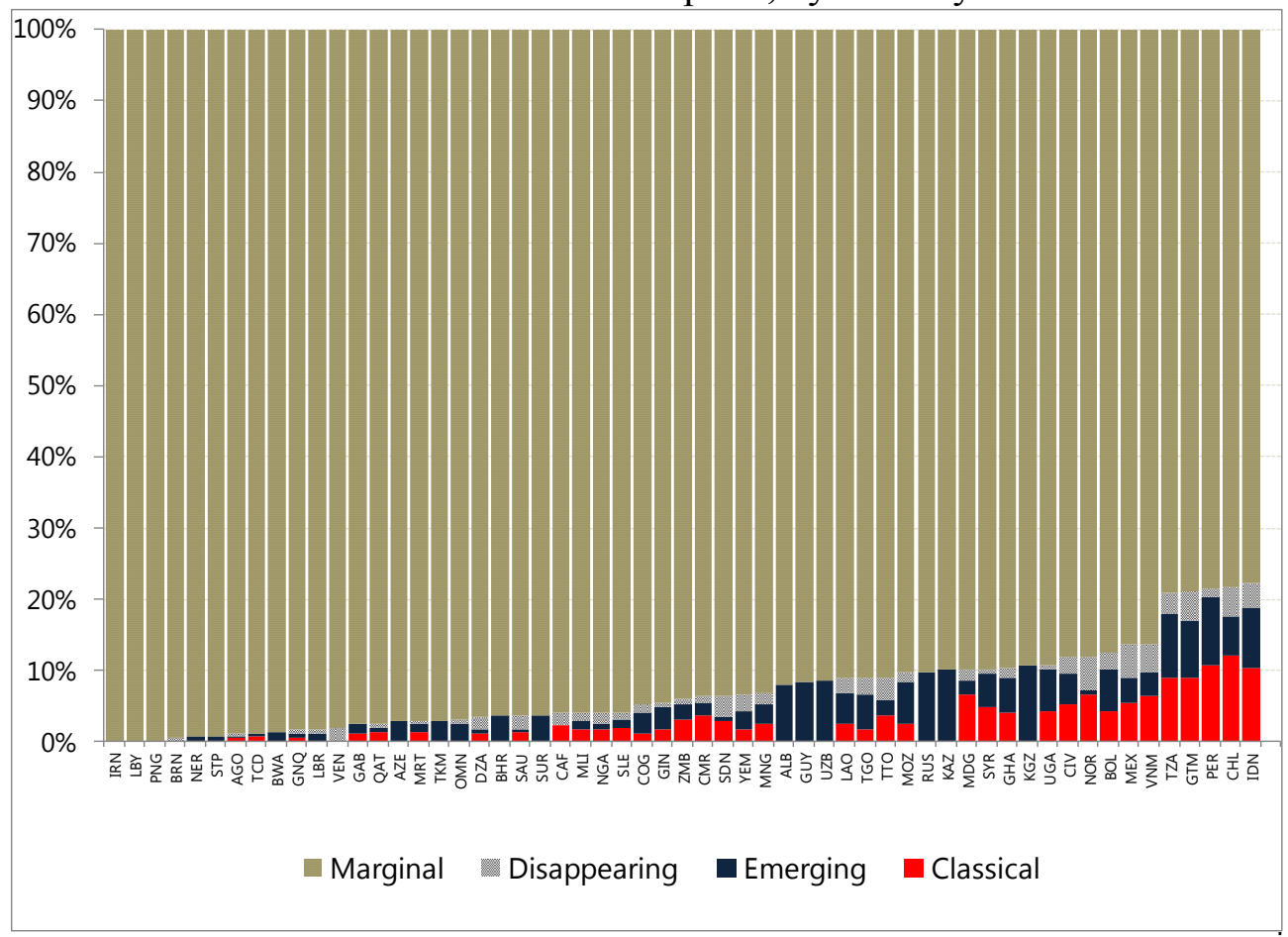


Panel C. NRE Manufacturing Exports, by Country

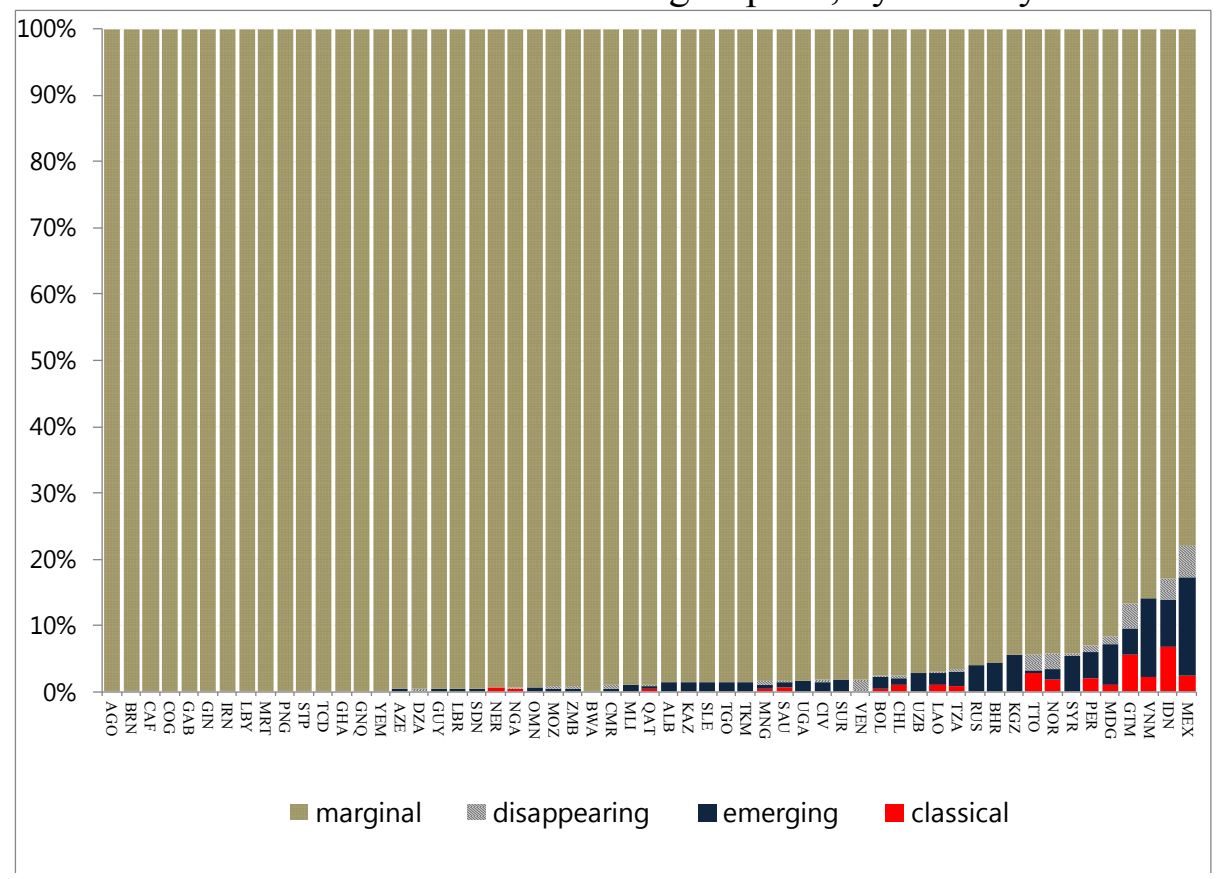

Panel D. NRE Service Exports

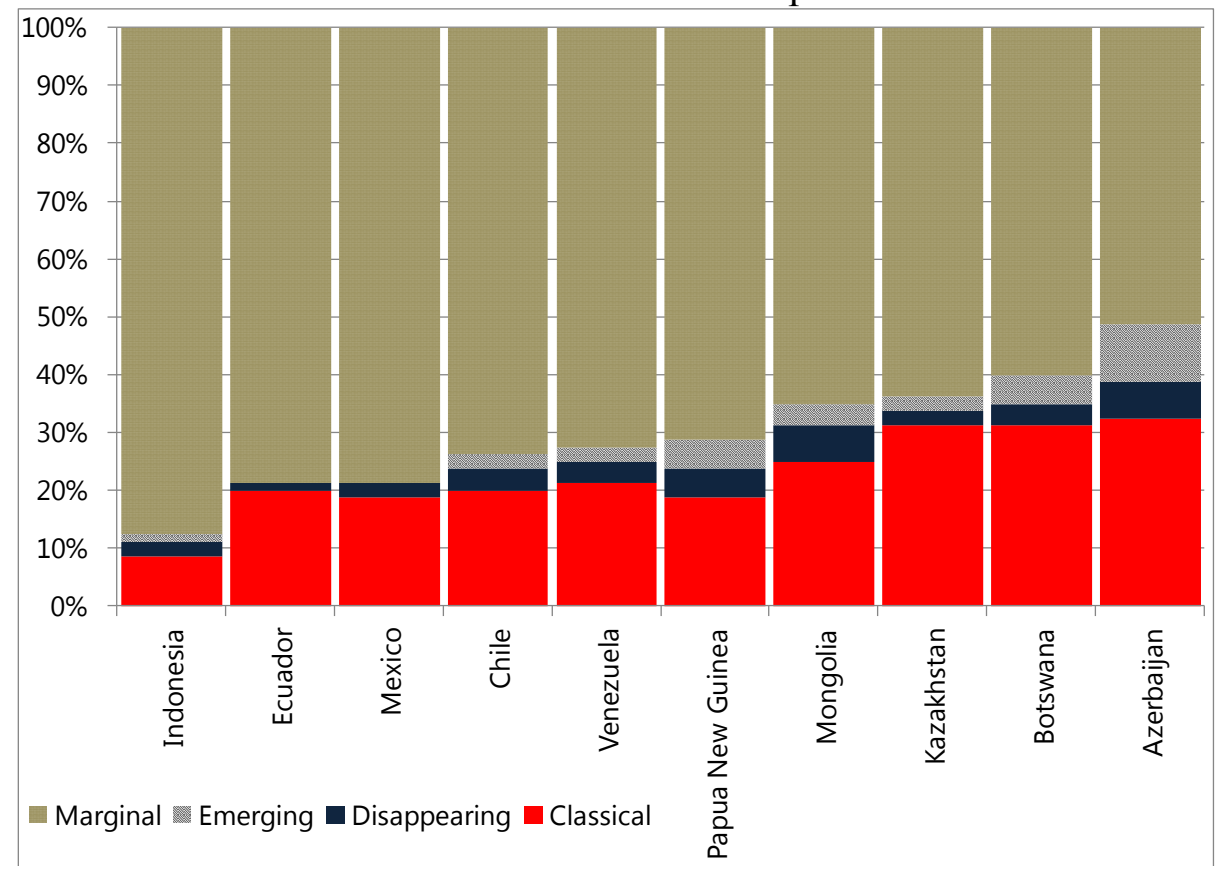


Panel E. Emerging Comparative Advantage in NREs Service Exports

\begin{tabular}{|c|c|c|c|c|c|c|c|}
\hline Export & Azerbaijan & Chile & Kazakhstan & Mongolia & $\begin{array}{l}\text { Papua New } \\
\text { Guinea }\end{array}$ & $\begin{array}{l}\text { Russian } \\
\text { Federation }\end{array}$ & Venezuela \\
\hline $\begin{array}{l}\text { Agricultural, mining, and } \\
\text { on-site r rocessing } \\
\text { Construction in the } \\
\text { compiling economy }\end{array}$ & & & & & $\mathbf{\square}$ & & \\
\hline Financial services & & & & & $\square$ & & \\
\hline Freight insurance & & & & & & & \\
\hline Health services & & & & & & & 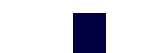 \\
\hline Military units and agencie. & & & & & & & \\
\hline $\begin{array}{l}\text { Operational leasing } \\
\text { services }\end{array}$ & & & & & & & \\
\hline Other business travel & & & & 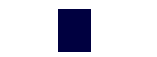 & & & \\
\hline Other direct insurance & & & & & & & \\
\hline Other transport - Other & & & t & & & & \\
\hline Rail transport- Passenge & & & & & & & \\
\hline Reinsurance & & & & & & & \\
\hline $\begin{array}{l}\text { Telecommunication } \\
\text { services }\end{array}$ & & & & & & & \\
\hline
\end{tabular}


Table I. Sources of GDP Growth

\begin{tabular}{|c|c|c|c|c|c|c|c|c|c|c|c|c|c|}
\hline \multirow[b]{2}{*}{ Group1 } & \multirow[b]{2}{*}{ Nre } & \multicolumn{3}{|c|}{ Capital Stock } & \multicolumn{3}{|c|}{ Human Capital } & \multicolumn{3}{|c|}{ Labor } & \multicolumn{3}{|c|}{ TFP } \\
\hline & & $1970-89$ & $1990-99$ & $2000-12$ & $1970-89$ & $1990-99$ & $2000-12$ & $1970-89$ & $1990-99$ & 2000-12 & $1970-89$ & $1990-99$ & $2000-12$ \\
\hline \multirow[t]{2}{*}{ EM } & EMs & 5.179 & 3.310 & 4.095 & 1.110 & 0.886 & 0.558 & 2.752 & 1.792 & 1.878 & -0.118 & 0.300 & 1.224 \\
\hline & NRE & 5.011 & 2.451 & 4.197 & 1.627 & 0.977 & 0.795 & 3.364 & 2.797 & 2.371 & -0.240 & 0.559 & 0.731 \\
\hline \multirow[t]{2}{*}{ LICs } & EMs & 2.729 & 2.513 & 4.577 & 0.944 & 0.848 & 1.049 & 2.840 & 2.660 & 2.706 & -0.256 & 0.302 & 1.379 \\
\hline & NRE & 2.768 & 2.523 & 3.546 & 1.070 & 0.806 & 0.796 & 2.503 & 2.824 & 2.696 & -0.214 & 0.919 & 1.710 \\
\hline
\end{tabular}

Table II. Summary of Growth and Productivity

\begin{tabular}{|c|c|c|c|c|c|}
\hline & \multicolumn{2}{|c|}{ EM } & \multicolumn{2}{|c|}{ LICs } \\
\hline & & Non-NRE & NRE & Non-NRE & NRE \\
\hline \multirow{3}{*}{$\begin{array}{l}\text { Median GDP per capita } \\
\text { growth rate }\end{array}$} & $1970-89$ & 2.327 & 2.612 & 0.576 & 0.571 \\
\hline & $1990-99$ & 2.302 & 2.153 & 1.199 & 1.977 \\
\hline & $2000-12$ & 3.524 & 3.535 & 3.362 & 2.936 \\
\hline \multirow{3}{*}{$\begin{array}{l}\text { Median Labor productivity } \\
\text { growth rate }\end{array}$} & $1970-89$ & 1.768 & 1.388 & 0.597 & 0.218 \\
\hline & 1990-99 & 1.524 & 1.086 & 0.603 & 1.415 \\
\hline & 2000-12 & 2.801 & 2.488 & 2.960 & 2.642 \\
\hline \multirow{3}{*}{$\begin{array}{l}\text { Median Capital deepening } \\
\text { contribution }\end{array}$} & $1970-89$ & 1.101 & 0.950 & -0.008 & 0.135 \\
\hline & $1990-99$ & 0.759 & -0.003 & 0.042 & -0.182 \\
\hline & $2000-12$ & 1.290 & 1.042 & 0.864 & 0.329 \\
\hline \multirow{3}{*}{$\begin{array}{l}\text { Median Labor Utilization } \\
\text { growth rate }\end{array}$} & $1970-89$ & 0.564 & 0.266 & -0.130 & 0.009 \\
\hline & $1990-99$ & 0.429 & 0.789 & 0.002 & 0.439 \\
\hline & 2000-12 & 0.827 & 0.849 & 0.239 & 0.399 \\
\hline \multirow{3}{*}{$\begin{array}{l}\text { Median Human capital } \\
\text { contribution }\end{array}$} & $1970-89$ & 0.572 & 0.582 & 0.582 & 0.630 \\
\hline & $1990-99$ & 0.442 & 0.372 & 0.486 & 0.470 \\
\hline & $2000-12$ & 0.291 & 0.265 & 0.626 & 0.474 \\
\hline \multirow[t]{3}{*}{ Median TFP growth rate } & $1970-89$ & -0.153 & -0.267 & -0.269 & -0.240 \\
\hline & 1990-99 & 0.273 & 0.548 & 0.283 & 0.898 \\
\hline & $2000-12$ & 1.202 & 0.690 & 1.350 & 1.667 \\
\hline
\end{tabular}

Source: Authors' calculations Penn World Table Version 8.0, UN National Accounts Database, International Labor Organization, GGDC, WDI, and IMF (2014).

Notes: Emerging market (EM) NREs include Algeria, Azerbaijan, Botswana, Chile, Ecuador, Gabon, Indonesia, Iran, Iraq, Kazakhstan, Libya, Mexico, Russia, Suriname, Syria, and Venezuela. Low income (LIC) NREs include Bolivia, Cameroon, Laos, Liberia, Mali, Mongolia, Niger, Nigeria, Vietnam, Zambia. The chart presents the median value across the region. 
Table III. Labor Productivity Growth in NREs

\begin{tabular}{|c|c|c|c|c|}
\hline Group1 & Country & $1970-89$ & $1990-99$ & $2000-12$ \\
\hline \multirow[t]{16}{*}{ EM } & Algeria & & & \\
\hline & Azerbaijan & & & \\
\hline & Botswana & 8.99 & 2.53 & 1.96 \\
\hline & Chile & 0.68 & 4.04 & 1.23 \\
\hline & Ecuador & 1.78 & -0.06 & 1.87 \\
\hline & Gabon & -0.50 & -0.32 & -0.89 \\
\hline & Indonesia & 3.65 & 3.08 & 3.60 \\
\hline & Iran & -0.36 & 1.78 & 1.52 \\
\hline & Iraq & 3.03 & 6.54 & 1.66 \\
\hline & Kazakhstan & & -3.64 & 5.84 \\
\hline & Libya & & & \\
\hline & Mexico & -0.27 & 0.74 & 0.75 \\
\hline & Russia & & -3.42 & 4.72 \\
\hline & Suriname & & & \\
\hline & Syria & 2.22 & 2.09 & 3.04 \\
\hline & Venezuela & -1.60 & -1.09 & 1.86 \\
\hline \multirow[t]{10}{*}{ LICs } & Bolivia & -0.99 & 1.54 & 1.19 \\
\hline & Cameroon & 2.07 & -1.96 & 0.66 \\
\hline & Laos & 3.52 & 3.81 & 5.69 \\
\hline & Liberia & -1.38 & -2.66 & 1.01 \\
\hline & Mali & 2.65 & 1.81 & 1.21 \\
\hline & Mongolia & 3.78 & -2.15 & 4.67 \\
\hline & Niger & -2.77 & -1.91 & 0.19 \\
\hline & Nigeria & & & \\
\hline & Vietnam & 2.53 & 5.10 & 4.30 \\
\hline & Zambia & -1.86 & -2.40 & 3.39 \\
\hline
\end{tabular}

Avg. Labor productivit.. $-3.64 \underset{1}{1} \quad 8.99$

Source: Authors' calculations Penn World Table Version 8.0, UN National Accounts Database, International Labor Organization, GGDC, WDI, and IMF (2014). 
Table IV. Contribution of Human Capital and Capital Deepening To Productivity Growth

\begin{tabular}{|c|c|c|c|c|c|c|c|c|c|}
\hline Group1 & Country & $1970-89$ & $1990-99$ & $2000-12$ & Group1 & Country & $1970-89$ & $1990-99$ & $2000-12$ \\
\hline \multirow[t]{16}{*}{ EM } & Algeria & & & & EM & Algeria & & & \\
\hline & Azerbaijan & & & & & Azerbaijan & & & \\
\hline & Botswana & 1.101 & 0.587 & 0.141 & & Botswana & 3.438 & 2.897 & 3.216 \\
\hline & Chile & 0.489 & 0.225 & 0.294 & & Chile & 0.508 & 2.432 & 1.921 \\
\hline & Ecuador & 0.459 & 0.045 & 0.181 & & Ecuador & 0.390 & -0.236 & 1.042 \\
\hline & Gabon & 0.808 & 0.559 & 0.333 & & Gabon & -0.109 & -1.435 & -0.790 \\
\hline & Indonesia & 0.391 & 0.409 & 0.396 & & Indonesia & 2.196 & 3.707 & 2.120 \\
\hline & Iran & 0.594 & 0.811 & 0.391 & & Iran & 2.761 & -0.510 & 0.802 \\
\hline & Iraq & 0.298 & 0.142 & 0.172 & & Iraq & 2.541 & -4.844 & -0.098 \\
\hline & Kazakhstan & & 0.889 & 0.137 & & Kazakhstan & & 0.941 & 0.418 \\
\hline & Libya & & & & & Libya & & & \\
\hline & Mexico & 0.660 & 0.521 & 0.397 & & Mexico & 0.205 & 0.547 & 1.119 \\
\hline & Russia & & 0.517 & 0.193 & & Russia & & 1.917 & 0.099 \\
\hline & Suriname & & & & & Suriname & & & \\
\hline & Syria & 1.034 & 0.091 & 0.322 & & Syria & 0.882 & -0.417 & 0.975 \\
\hline & Venezuela & 0.333 & 0.258 & 0.440 & & Venezuela & 0.709 & -0.999 & 0.370 \\
\hline \multirow[t]{10}{*}{ LICs } & Bolivia & 0.907 & 0.577 & 0.496 & LICs & Bolivia & -0.660 & 0.383 & 0.261 \\
\hline & Cameroon & 0.924 & 0.601 & 0.376 & & Cameroon & 0.877 & -1.074 & 0.451 \\
\hline & Laos & 0.704 & 0.580 & 0.551 & & Laos & 0.283 & 1.492 & 2.437 \\
\hline & Liberia & 0.708 & 0.456 & 1.124 & & Liberia & -0.857 & -0.958 & -1.576 \\
\hline & Mali & 0.278 & 0.308 & 0.875 & & Mali & 0.927 & 0.313 & -0.018 \\
\hline & Mongolia & 0.572 & 0.094 & 0.135 & & Mongolia & 3.269 & 0.100 & 0.573 \\
\hline & Niger & 0.215 & 0.268 & 0.319 & & Niger & -1.123 & -2.188 & -0.709 \\
\hline & Nigeria & & & & & Nigeria & & & \\
\hline & Vietnam & 0.149 & 0.492 & 0.770 & & Vietnam & 0.295 & 2.862 & 2.557 \\
\hline & Zambia & 0.784 & 0.849 & 0.344 & & Zambia & -0.938 & -0.801 & 0.811 \\
\hline
\end{tabular}

Avg. Human capital co..

Avg. Capital deepenin..
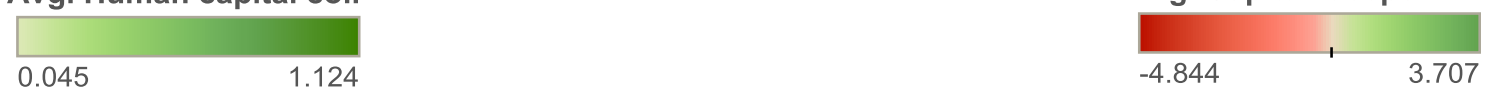

Source: Authors' calculations Penn World Table Version 8.0, UN National Accounts Database, International Labor Organization, GGDC, WDI, and IMF (2014). 
Table V. TFP Growth in NREs

\begin{tabular}{|c|c|c|c|c|c|c|}
\hline \multirow[b]{2}{*}{ Group1 } & \multirow[b]{2}{*}{ Country } & \multicolumn{3}{|c|}{ Year (group) } & \multicolumn{2}{|c|}{ Avg. TFP growth rate } \\
\hline & & $1970-89$ & $1990-99$ & $2000-12$ & & \\
\hline \multirow[t]{16}{*}{ EM } & Algeria & & & & -5.86 & 11.25 \\
\hline & Azerbaijan & & & & & \\
\hline & Botswana & 4.45 & -0.96 & -1.40 & & \\
\hline & Chile & -0.32 & 1.38 & -0.99 & & \\
\hline & Ecuador & 0.93 & 0.13 & 0.65 & & \\
\hline & Gabon & -1.20 & 0.56 & -0.43 & & \\
\hline & Indonesia & 1.07 & -1.03 & 1.09 & & \\
\hline & Iran & -3.72 & 1.48 & 0.33 & & \\
\hline & Iraq & 0.20 & 11.25 & 1.59 & & \\
\hline & Kazakhstan & & -5.47 & 5.28 & & \\
\hline & Libya & & & & & \\
\hline & Mexico & -1.13 & -0.33 & -0.77 & & \\
\hline & Russia & & -5.86 & 4.43 & & \\
\hline & Suriname & & & & & \\
\hline & Syria & 0.30 & 2.42 & 1.74 & & \\
\hline & Venezuela & -2.64 & -0.35 & 1.05 & & \\
\hline \multirow[t]{10}{*}{ LICs } & Bolivia & -1.24 & 0.58 & 0.43 & & \\
\hline & Cameroon & 0.27 & -1.48 & -0.17 & & \\
\hline & Laos & 2.53 & 1.74 & 2.70 & & \\
\hline & Liberia & -1.23 & -2.16 & 1.46 & & \\
\hline & Mali & 1.44 & 1.19 & 0.36 & & \\
\hline & Mongolia & -0.06 & -2.34 & 3.96 & & \\
\hline & Niger & -1.86 & 0.01 & 0.58 & & \\
\hline & Nigeria & & & & & \\
\hline & Vietnam & 2.08 & 1.75 & 0.97 & & \\
\hline & Zambia & -1.71 & -2.44 & 2.23 & & \\
\hline
\end{tabular}

Source: Authors' calculations Penn World Table Version 8.0, UN National Accounts Database, International Labor Organization, GGDC, WDI, and IMF (2014). 